


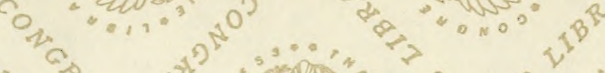

$0_{2}+1,=30^{2}$

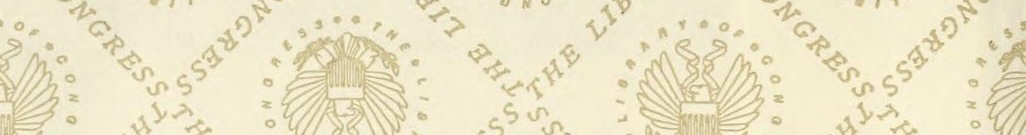

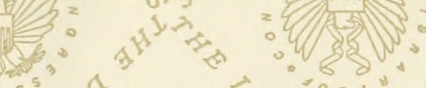

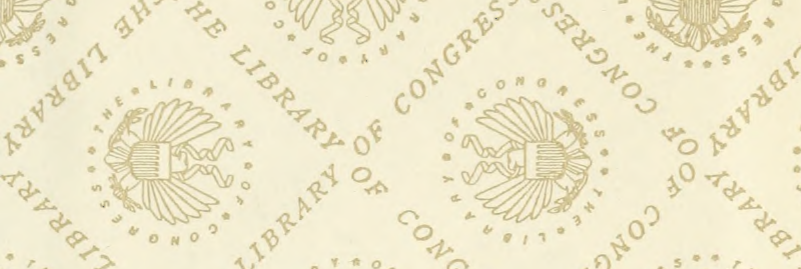
2)

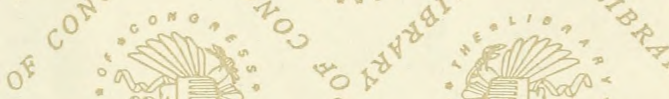

s

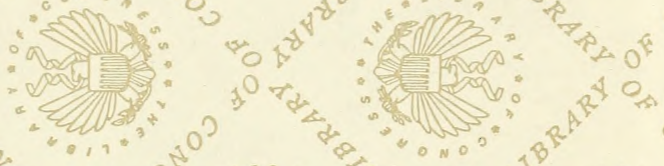

So,

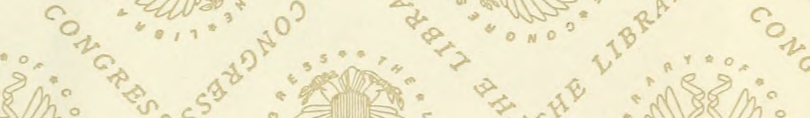

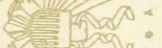
$i_{s}$

$=$ (1). $\beta^{3}$

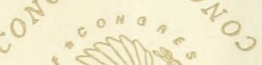




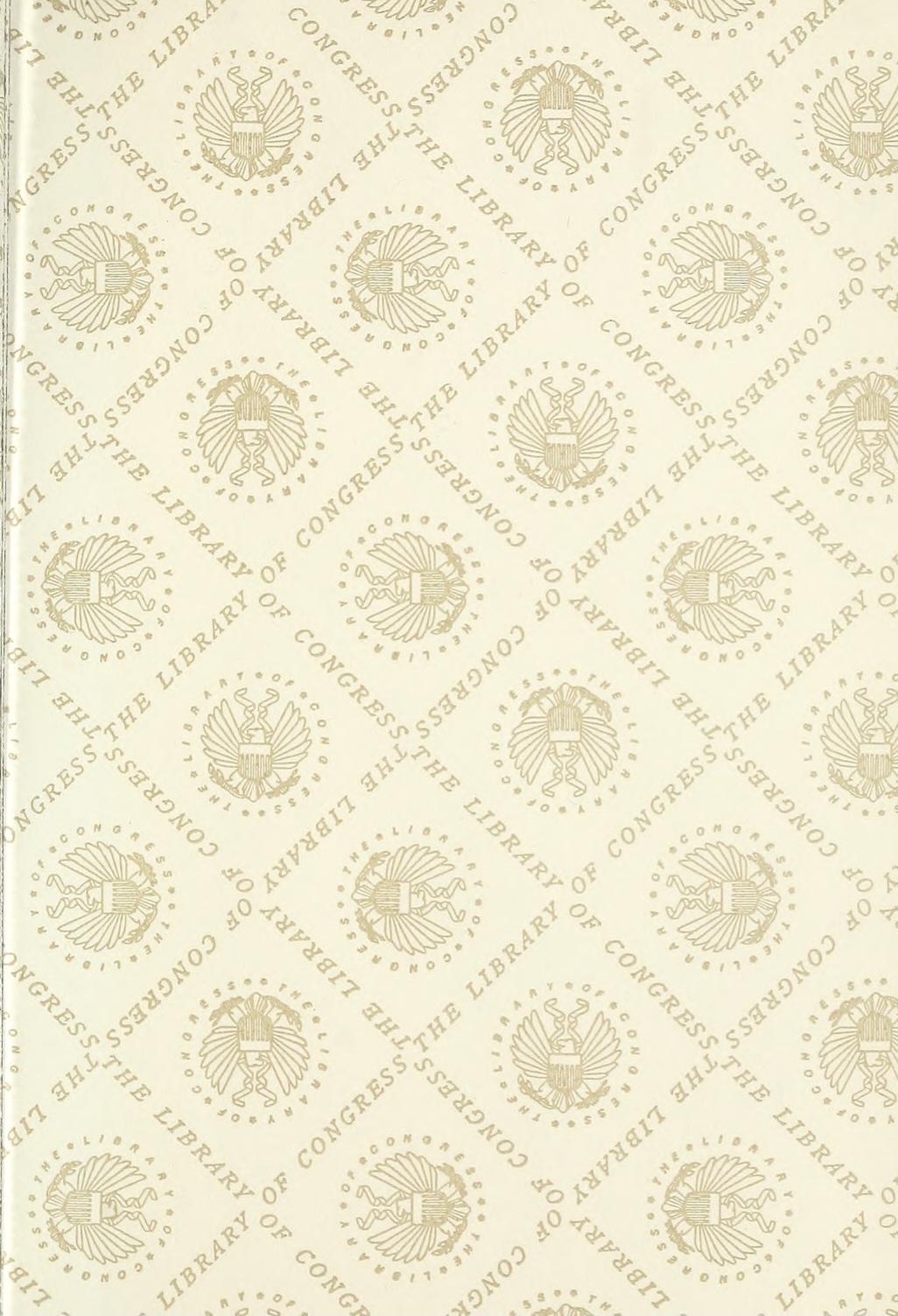




$$
\text { : }
$$




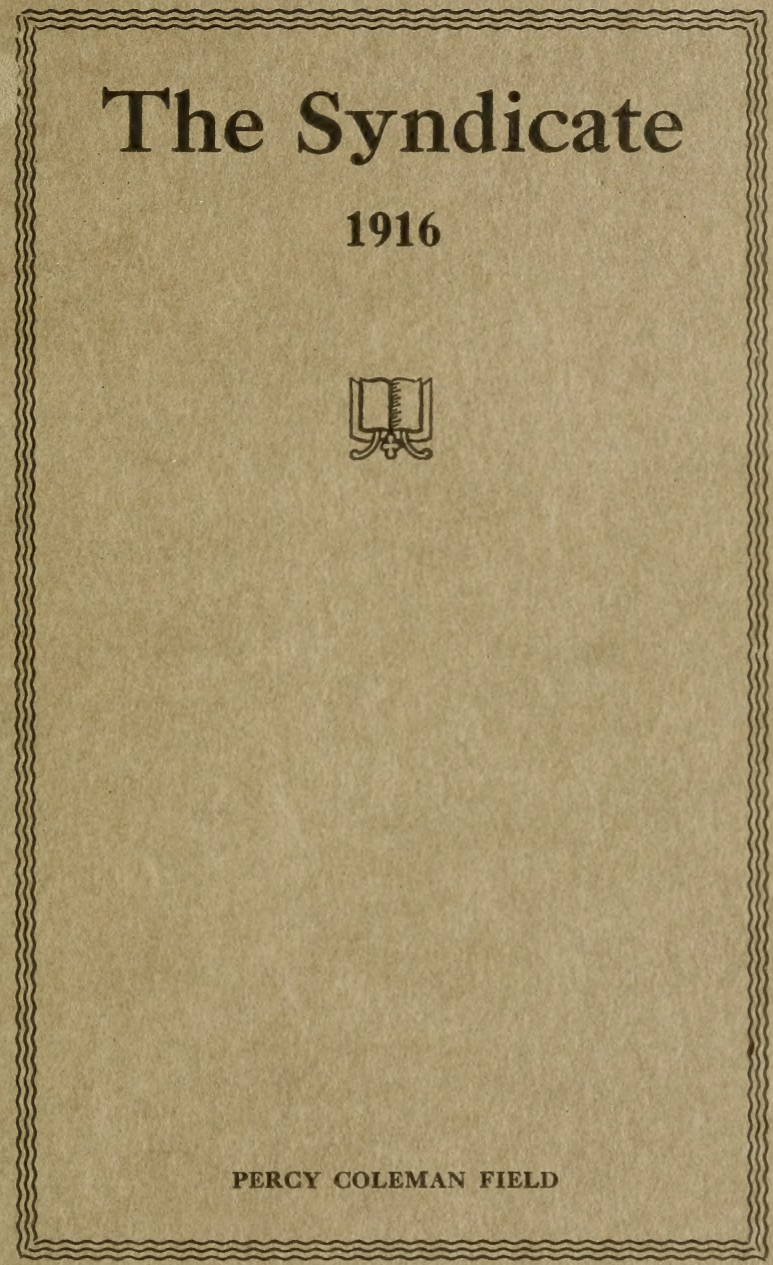





\section{The Syndicate \\ 1916}

PERCY COLEMAN FIELD

h 


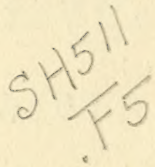

\section{JOHN $21-3$}

"Simon Peter saith unto them, I go a fishing. They say unto him, we also come with thee."

\section{JUL $24 ! 917$}

\section{(C) 1.4470396}

Copyright, 1916, by Percy Coleman Field

All rights reserved

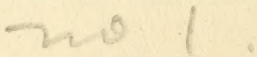




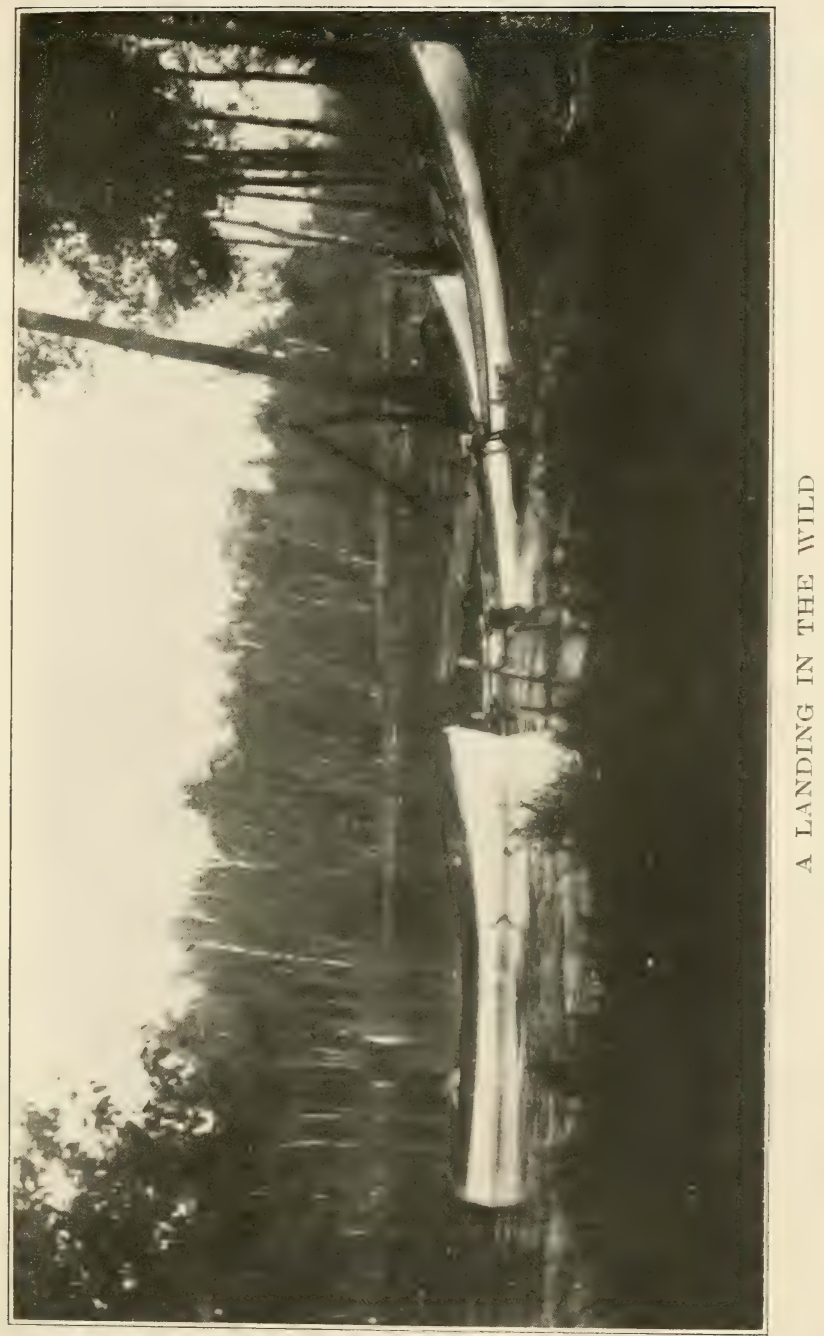




\section{THE SYNDICATE 1916}

\section{CHAPTER I}

In the year of our Lord one thousand nine hundred and sixteen the Syndicate, by unanimous vote, decided to take an outing in the northern part of Minnesota, in what is commonly known as the "wonderful Leech Lake country."

The Syndicate! What is that? In this instance, it is a number of good fellows who have banded themselves together for the purpose of enjoying the vacation of 1916.

Now that the happy hours have passed and we are back in our native land, I shall endeavor to recall the various menbers as they appeared; the things they did and said; their inner life, as exposed in travel and about the camp. In doing so, it will be my pleasure to reveal a great number of the many idiosyncrasies, characteristics and philosophies which have tended to make their lives worth while.

\section{CHAPTER II}

Of course, with our party there must be a merryfaced man. He is a little over six feet in height; yet, by reason of his good nature and eorpulency, he does not have the appearance of being exceedingly tall. He is one of the big boys of this world both of mind and body. His inner soul might be romantic, yet he is so biinful of reality that his friends have little or no 
time to enjoy his romance. Like a great many other merry-faced men, he has large blue eyes from which radiate joy; and, of course, they are subject to all sorts of winks, blinks and rolls, such as the joke he is just playing, or is about to play, demands. He possesses a very pleasant face indeed, such as you will find on the body of a man of his stature. It is clean-shaven, excepting for a princely mustache he raised for the occasion of this vacation; and this, together with a beard, he also raised and cut-according to the old German style-might have raised a doubt as to his nationality; yet, when you come to know him, as I have, and do, you will find him an American through and through.

From my association with him, he is fond of bright colors. I find him on the bank of Kabekona bay (a tributary of Leech Lake) in a style most becoming to the taste of one of the southern portion of Italy.

In my memory, I shall always see him as he appeared there. A very large western hat is resting upon his head, pushed well back, revealing a large portion of the top of his head, which locks as if it might have keen the battle-ground of two common warriors: brain versus hair; and, while the generals of hair have been persistent, and for many years seem to have had the better of the contest, yet, now, owing to the fact that my dear friend has allied himself with the commanders of hair, he shaved the major portion of the top of his head, and thus, he appeared like the majority of our party, slightly bald. Yet he does love bright colors, for around his neck he wore a big red bandana handkerchief, which blended very harmoniously with the color of his head, cheeks and arms, after he had spent his first day on the water and was a sun-kissed beauty. Around his waist he wore, much to his pleasure and 
comfort, and, slightly, shall I say, to the discomfort of a certain member of his family, a large Scotch plaid vest. The vest had the appearance of being one of his true loves. He wore it upon all occasions, and to look at it, a casual observer could readily see that it had been worn upon equally as many more.

This particular friend of mine was a doer. He was quiet about doing everything excepting sleeping. When he was doing that-oh, well, with the joy and delight that sleep brings to a little child, he could turn the veritable wilderness of the banks of Kabekona Bay into a sawmill center. You could hear the buzz, buzz, buzz of the saws; the popping of the engine, and every now and then you could hear the saw strike a knot; then you could hear the big logs roll, the engine hiss and groan; the foreman giving orders; yet, with all, he would enjoy a refreshing night's sleep and be up and doing long before the rest of the crowd were through talking about the duties they were to perform.

And such is a small portion of the character of my friend, Remus F. Atwood, Commercial Agent of the Chicago, Rock Island \& Pacific Railway Company.

For his happy smiles and harmless pranks, pure logic and good reason, I shall always enjoy my association with him at Leech Lake.

\section{CHAPTER III}

There is another member of the Syndicate, which the Syndicate could by no means and under no conditions or circumstances spare. $\mathrm{He}$ is a chief mechanic, chief fixer, chief everything. If there was water in the gaso- 
line, he was to blame for it. If a "do-dad," as one very distinguished member of the Syndicate was bound to call crexything not particulails mentionod in an insurance policy, wouldn't work, he was the one to fix it. He was always roady and willing, never tiring, would not shirk, always leady to do anything, or everything.

He was considerably older than any other mombar of the Syndicate at four a. m. and eleren or twelve p. m. He liked his slecn, and with all he possessed a virtue which was absolutely foreign to all other members of the Syndicate. He was a quiet sleeper; or, at any rate, I never did hear him after he tucked limself into his blankets. Possibly this might be accounted for by reason of the fact that there were so many noisy fellows in and about the camp. When morning came to him, and it seemed always to be corning to him, he was one of the early birds, fixing this, fixing that, putting the proper amount of oil into the susoline and preparing the motors for the trip of the day. He always had a good appetite, like the rest of the Syndicato. He was one of the boys, alrays ready to seine for mimnows ca:ly in the moming; was ready and willing to diag the not through the cold water, when the riort vas on the ground; always on hand for everything, and had plonty of time to look after the wants of exerybody.

When I think of his willingness-and God biess and reward him for it; some may, yet I feal too many will not-I can't help but feel that ho is going to be a very busy man.

He doesn't look much like his father in sire, yet when it comes to being a good fellow he is a chip of the old block, and the old block can be well proud of him.

This member of the Syndicate is Mr. Dan Atwood. 


\section{CHAPTER IV}

There are two other distinguished members of the Syndicate. One is plump, yet not too fat; the other is thin, yet not what you would call skinny; one has a fine suit of hair on the top of his head, while the other would have equally as much on his face, would he permit it to grow there. In common, they both have blue eyes; and in this way they resemble each other, while in most other things and undertakings they are different, yet their inner souls may interlock in many of the finer conceptions.

One of these dear friends enjoys canoeing; the other did at one time in his life, but owing to the trials and tribulations of this cold world, and water as well, doesn't care so much for it as he used to in days gon by. One likes to explore the lake, while the othe: would rather fish in it; one enjoys telling a good story, while the other delights in listoning; and yet, with these divergencies of character, God never put me in touch with two such pleasant individuals as the "Two Pettibones": to know one of them is to enjoy the hidden characteristics of the other. Each of the two are well educated. They have read all sorts of books and know somethirg intoresting about everything.

Cne of them enjoys cooking and is an old master in the culinary art; and under his inctruction, a bronze looking fellow-who has by the humanity of the balance of the crowd been permitted to become a member of the Syndicate-has gained some distinction, while the other, Mr. Ira Pettibone, would rather chop wood.

The chief chef, Mr. Charles I. Pettibone, usually covered his very bald head with a soft hat. He dressed himself very dudishly in khaki clothes at camp. $\mathrm{He}$ 
wore, among other things, a khaki coat, a khaki vest, a woolen shirt, a blue tie and khaki trousers.

Mr. Ira Pettibone at camp wore clothing of a sort that sounded very much like khaki but spelled differently. In fact, he was very much like a number of other prominent members in dress: might have been taken at first blush in and about Leech Lake for anyone excepting himself.

Such is a small glimpse of my two friends, Mr. Charles I. Pettibone and Mr. Ira Pettibone.

\section{CHAPTER V}

There is another young man of our party. He is a proud father of three boys, who have grown to be young men. He is as young as our other good friend, Doctor Leonard. In fact, they were, and are, boys together. To know him is to like him, and to like him is to form a desire to become better acquainted with him; and when one does become acquainted with him, you can't help but feel good, and very good, too, over knowing him. He is a sturdy man, nearly six feet tall. He has blue eyes and a very kind face. Upon his face you see a cunning smile, and a shaip twinkle flashes from a pair of shrewd eyes.

He has become acquainted with everybody and through his frankness always slips into the inner chamber of their graces or vices. He, too, like his young friend, Doctor Leonard, possesses a heap of charity for the weakness of others, and is always willing to reason a fellow into the better way of living, rather than to push him down. 
He is a Baptist through and through. From my acquaintance with him, a good Baptist. He appeared to me to have a far better command over his religion than many good Baptists, in that his religion tends to make you like hirn better for it and to make his associates happier.

$\mathrm{He}$ is engaged in the railroad business, and when the railroad business demanded his attention I am quite of the notion that a good many of the sharp horse traders gave a sigh of relief, for I am sure that his cunning eye could always detect a spavin or a ringbone.

At Kabekona he was by trade, or profession, a woodchopper. He kept the wood box full of nice dry wood, and did a multitude of other things which made life easy and comfortable for the older members of the Syndicate.

He has maintained that he was in the possession of a cake of shaving soap when he first arrived at camp, and has since contended that he has been divested of it by strategy or otherwise; and he has filed suit for everything but the possession of said soap, or its value, before one of the Supreme Courts of Bunkum, wherein each members of the Syndicate sits as a justice. I suspect, through his cunning, he intends to win his case, yet the shaving soap at our camp, I am afraid, is much like time and tide: it waits for no man.

Another characteristic is that he is thoughtful of everything and everybody. Yes, many of us feel very thankful indeed to him for his thoughtfulness in bringing the shaving soap. Were it not for his thoughtfulness, in this regard, the faces of those in and about the camp would have been a veritable brush pile.

So, with these few remarks, I have the pleasure of introducing to my friends Mr. DeWitt Clinton Stephenson, hereinafter known as Clint. 


\section{CHAPTER VI}

When I recall our vacation I cannot help but think of anothel very-yos, very distinguished member of the Symicate. He hiss lived in Kansas City for a long time. He was commecterl with the Chicrgo, Rock Island \& Pacific Puilway Commony for twenty-five years. Ha was it: Genorn? Agent. The a ailload company, howeve;, did not approciate his tolent to its fullest extent and at the empiration of this perind of faithful service he sta:ted in the insurance business for himself. He has made a creat suecess both in business and in life, and is now General A eent of the President Life \& Trust Company. This is his minor consideration; his major undertaking is that of a proud father. He is the possessor of a dear wife, to him the dearest of all heavenly charms; for whom he would brave the rough waves of the lake, go through thick or thin; and even while on oui. trip would venture at night to travel from camp to Walkor for a letter from his "honey." I mention this little characteristic of my friends as it portrays his whole life. He is sincere. Yes, sincere in everything. And, of course, we love him for his sincevity, and his many, many other virtucs. He is one of the big, strong mon, always willing to do more than his share of the hard work; never admits he is tired; up early and goes to beil late. God seems to have given him so many virtuns that possibly some of his hearing has, in this ways been arowded ant. I mention this to explain some of the things which happen.

This paticular fircnd, being a strong character, wears a st:ong face and sometimes a stern look; yet he is so full of love for his fallowman that his sternness is always forgotten by his pleasant smile and good en- 
deavors. He weighs something over two hundred pounds. He is nearly six feet tall. His hair is very thin on the top of his head, while his beard is very hesvy. He has a strong chin, a determined mouth, a continental nose, gravish blue eyes, which look into the very depths of your soul.

In his business life his clothing is in harmony with his teste. While at Kabcliona he wore a costume rery sinilar to that of my fiend Ira; yet the cut of his trousers was slightly different, in that he had cut атлау flom the bottom of the leg's all of the surplus cloth. Thus from a distance he appeared as one in gaiters: a veritalle Mr. Piolkwiok of the party. Indeed, he had ? way of wearing a pair of glasses on the end of his nose and looking over the top of them which very closely resembled our eminent friend; and then so many thing happened to him, as a result of his honest endeavor, that possibly it will be pleasant to so consider my friend, Mr. Frederick W. Segur.

\section{CHAPTER VII}

There is another very prominent member of the Syndicate. In his character you will find all of the cardinal virue: and the eroatest of all: charity, charity for the fraility of humanity. A rreater portion of his life has been spent for the crod of his fellorman. To become really acquants with this rare jewel of humanity is a particular privilege. I feel very thankful, indeed, for the time I have been with him.

On our trin. and. as far as that is concerned, everywhere-lot what come that would, and he will be the same. 
$\mathrm{He}$ is one of the young men of our party.

His hair, what little time and trouble has spared him, is white. For a while, at Kabekona, he wore a shaggy mustache and then a certain member of the Syndicate cut it.

This distinguished friend of mine delights in cooking. Yes, in cooking everything, especially cakes; and when I think of what a wonderful filler his cakes were at breakfast I can't help but feel that the medical and surgical professions have robbed us of one of the greatest chefs. Yet, what care we for a chef when we are sick?

$\mathrm{He}$ is known to the Syndicate as Doc. It is Doc this and Doc that; Doc, drive the nail here to hold the dock; Doc, here, please, for goodness sake, pull this fish bone out of my throat; Doc, for a story; Doc, for philosophy. In fact, and as a matter of fact, it is Doc for everything, at all times and on all occasions; and the best of it all is that he has time for everything and everybody, and especially the ladies. In fact, one of our party-I will not say which one because I mean each one-coveted his standing with the ladies to such an extent that I believe that the particular one, and I mean each one, wanted to be known as Doc, so that he would have free admission into the hearts of the fair ones. Yet, when we come to think of it, that would be of no avail, so we will have to consider his success due to his personality.

Such is a portion of the personality and life of my good friend, Doctor Homer O. Leonard. 


\section{CHAPTER VIII.}

There is another individual who has been honored by being a member of the Syndicate. He is six feet tall. He weighs over two hundred pounds. In the summer of 1916 he was of a very bronze complexion. He has blue eyes. He is strong and active, capable of doing most any kind of hard work, yet it has been a long time since anyone has accused him of it.

$\mathrm{He}$ is a lawyer and enjoys that profession as a livelihood, and is now a member of the law firm of Williams, Guffin \& Field.

He lives on Sixtieth Street, in the Swope Park vicinity of Kansas City, where he enjoys life to its fullest extent.

$\mathrm{He}$ is the father of two darling girlies.

You will find a number of interesting things about him at home: there is a lovely wife, a preacher's daughter, who delights in keeping a good home for him and his family. In the spring time you will find him among the roses, honeysuckles and sweet peas; and, as summer progresses, in his garden, where a number of his friends enjoy going with him; while around his house you will find a number of chickens and a yellow dog, who possesses a family tree.

When he was a small boy destiny robbed him of his father and mother, and thus he has been confronted with an innumerable lot of experiences. He has a varied education; has studied at many schools and has graduated from, among other institutions, Yale University.

He enjoys associating with men, and especially prizes the time he has spent with the Syndicate. 
At camp he wore an old pair of corduroy trousers, a heary pair of shoes or rubber boots, a woolen shirt, a sweater and a hunting coat.

He enjoyed everything, even cooking for the whole Syndicute. He apportioned the amount of food he would cook by his own appetite, and thus the Syndicate to a man was well fed. Besides being cook, he was a sort of a general engincer of the big launch and spent a considerable time wiesting with the motor.

While in the northland countpy he wore a Charlie Chaplin mustache and a beard on the cnd of his chin.

Thus we have smme of the peculiarities and characteristics of Percy C. Field.

\section{CHAPTER IX.}

Iriday. Aveut the 11th, 1916, the sun shone very wrimhty indeed. Ever thing was happy and gay with the Syndiate notwithstanding the fact that we were in the nidst of a long hot, dry summer. It was the 11th day of August, the day set for the Syndicate to travel to a new land, mpon which the sun shines with comiortable warnith and where the air is delightfully conl; where, at nighis, we could sleep under blankets and enjoy the same cool rostfulness as we experience at home in the latter part of October or the first pait of November.

Pency Field arose at an carly hou this moming. He wos anfmnen? by a stream of sneezes. These inecxes, while they announcad the oncoming of what is commonly called the hay fover, were of no consequenee, for it was onig a little while until he, togethei with a 
number of others, would be fishing in the cold waters of Leech Lake and its tributaries, where the sneeze would be a thing of the past and he would be refreshed.

Fie anticipated this pleasure with such keenness that long before the time for the Rock Island northbound train to leave for St. Paul he had purchased his tichets and made his reservations. He was thoroughly prepared. His trunk was packed. First of all the fishing tackle, poles and fishing boxes were placed in his trunk; then his fishing clothes, his heavy blankets, heavy underclothes, sweater, woolen shirts and all sorts of wintor wear, which seemed in the midst of the hot month of August, at Kancas City, to be a comedy upon nature itself. So by afternoon all ras in readiness, as far as Percy Field was concerned, and, I dare say, the rest of the Syndicate, for he was, and they were, going into God's great out-of-doors in the far, far away Northland; to get close to nature itself; to live; to fish; to enjor the fresh air; to exercise; to swim; to fall into the lake; to swim out; to dry his clothes on the oldfoshimed clothes line, the limb of a tree; to have a cenuine vescetion and lesve the world and all behind; and, most of all, to as ociote with his friends; to be a companion of men, who have lived near the standard of what was intended as best for them, a rare opportunity and a treat for a young man. This ras his pleasure and such did the time and occasion promote for each member of the Syndicate.

Br nine o'clock p. m. the keen anticipation of Percy Ficld for the trip prompted him so that he went down and boaided the Rock Island train. The train was billed to lenve at eleven fifteen p. m. At nine the train was on tract. Fnd as the barths were all made he tucked himedf in, and in a littls while sneezed himself to sleep.

Near the approach of the midnicht hour there was a considerable commotion on the train. A number of 
sonorous voices were heard. A whole crowd of men had taken charge of the sleeper. They were busy finding their berths and quarters for the night. I was awakened by their hearty laughter; yet, not being thoroughly aroused, I lay still and listened.

"Where is he?" demanded a pleasant voice.

"I am sure he is here somewhere," answered another familiar voice.

A general search followed; seven men were looking for someone; and thus the porter came to their rescue, as does a Puliman porter at all times and on all occasions, while aboard a sleeper.

"Dare's a man in low' tin, dat's dun bin do'n a heap of sneezing; is he da purson?" offered a round-headed, black-faced man in a blue uniform and nickel-plated buttons.

Upon the direction of the porter to lower ten my friend Remus pulled back the curtains and exposed me to the full view of all standing in the aisle, including the Syndicate. I was delighted to see their happy faces and to shake their hands. I explained to them my condition and was permitted to lie a bed while they went to the smoking car and talked.

I was told by Remus, the next day, that Mr. Segur had kept guard over the balance of the crowd until the late hours of the night and had also out-winded all aboard in a little talkfest on the subject of life insurance; that there was a black whiskered man from Minneapolis, and also a newspaper reporter, who seemed to hold their own with him for a while; that is, until twelve thirty a. m., or later, at which time Remus felt the call of old King Slumber and went to bed. Remus said that they were chucked full of insurancedidn't have time to tell any stories, but just kept on, pro 
and con, but mostly con, until a late hour-one of the parties, and I will not have to mention his name, debated the issue as to whether a millionaire could afford to put one-third of his income into insurance, while the other took the opposite side of the proposition.

\section{CHAPTER X.}

Saturday morning, August 12th, 1916, came after a restless night. I was awakened this morning, not from a quiet and refreshing sleep, but from something in the nature of a coma, which had come upon me from the constant rumbling of the wheels, the putting on of the brakes, and all of the kindred noises of a railway car in motion.

There I lay in a shelf on the side of the car. The night before, while no one was looking, I had slipped off my clothing and plunged into bed. I was now ready for another effort. There I lay, clothes here, there and everywhere, and not a stitch of clothing which I was just ready to put on. I could find my trousers and my coat, but my underclothes seemed to have been left behind. My stockings had disappeared, and likewise my shoes, so just to be accommodating with the situation and my personal comiort, I lay there and thought about it.

Suddenly a large human foot plunged through the curtain and was in the act of stepping unceremoniously upon my stomach.

"Good morning," cried I, as I pioceeded to arrange a more satisfactory resting place for the foot of my early caller, when suddenly the foot made a gesture as if it desired to step out of the window.

"Is you in distress?" called a familiar voice, goodnaturedly. 


\section{"Yes," I shouted.}

"Well, suh, one at a time, gents-just put your han' on my shoulders, dis fcot on dis here round; dat's it." And then my early caller reached in his pocket for some token of real Pullman appreciation.

"Yes, suh; thank you, suh-them up'rs is suah an abomination," said the porter, with an old-fashioned laugh.

My curtains were pulled back, and there followed a very bald head into my compartment, apologizing for his intrusion, suggesting that he had a "narry" call. My early morning caller then drew his head out and up, when, of coutse, any ordinary fellow knows that the proper way to take a head out of a lower berth is to follow the same line of entree, at least-when suddenly he stuck the mahogany above and fell away.

Reslizing my undressed condition and feeling the pleasure a breakfast with the Syndicate would bing to me, I procesled to worm myself into some clothing. Never before dic! I imagine to what an extent J could twist and squirm. I was a contortionist. I managed to fish my underwear out from a portion of the mattress and $b y$ means of standing on the back of my head and one foot slid inio my trousers, first one leg and then the other. I didn't have any particular trouble in getting into my shirt, yet when it came to getting my shirt into my trousers I was confronted with a more selious diffeulty. I had the bigesest shirt imaginable, but, being in the habit of wearing a large, roomy shirt, procecder! to buckle my belt, thinking all was well. I made a dash for the dressing room in bare feet, when suddenly I was confronted with the reality that I was picking up my bed as I went. I stopped short and uncoupled myself fiom my unnatural caudal appendage. 
This was done to my satisfaction and chagrin. At that time a very charming faced lady of possibly twentyfive summers, in her natural color, as the hour for paints and powders had not yet come, laughed outright, and then turned her head the other way. In my embarrassment she did not think of the propriety of turning her head the other way before she had time to see and to smile; yet, the train at that moment gave a lurch which turned her head toward me, and with outstretched arms I was greeted. Of course, I said "Excuse me," and, of course, she begged to be excused; and so did a large, heavy-set, middle-aged gentleman, who had slept the night before across the aisle, beg to be excused for butting into the charming lady; and the charming lady, upon seeing a portion of his bald head emerge from the partly drawn curtains of the berth, for some unknown reason to me, of course, blushed and hurried away.

I finally managed to get into the dressing room. I was there for a shave. I found my shoes and stockings, after finding cveryborly else's shoes and stockings, and succeeded in putting my feet into my own shoes, while another guest and a swish of the train proceeded to give ne a shower bath and prepare me for my tonsorial effort. Being thus duly and truly prepared, I took out my broadside razor and steadied myself upon my right little toe and left heel, hung on to the rail and proceeded to draw the sharp edge of the knife over my jugular vcin. Upon finishing this operation with a free heart and easy nerve I turned about to find a number of the Syndicate and a few of the other passengers holding their breath.

"For the Lori's sake," said somebody, "you will never be nearer death." 
In the course of a great many efforts every member was in the pink of condition, awaiting further orders and announcements.

"Fust call for breakfes'!" came out of a very burrheaded individual, melodiously inviting everybody to the dining car.

The Syndicate to a man sprang to their feet. They rushed to the dining car. At the entrance of the diner a barrier was found. The iron gate had been raised. There stood the Syndicate in the front rank. We could smell the pleasant aroma of the coffee and the frying ham. Breakfast appeared to be ready. The Syndicate was ready for breakfast, but there was the gate barring the way. There was one very tanned individual, who, by virtue of wiping his nose most of the night before, was now the proud possessor of a very red nose; he stood for some moments and contemplated. He was athletic enough to have vaulted the gate. Upon careful investigation he found the key in the lock. The gate was then opened and in rushed the Syndicate. All of whom were comfortably accommodated.

A good breakfast was served at an extremely reasonable price from the viewpoint of the railway company. Yet, what cared we for the price. It, like our time, had been set apart and both had to be spent, so the one was given as cheerfully as the other.

As the train was very late into St. Paul, we had to await our time with patience; and while thus engaged Doc grew philosophical, ternpering his philosophy with a few verses.

"Boys," said Doc, as he drew himself close to the Syndicate, "how wonderful is it to be friends and companions of God. Let us consider that just a minute: it is what we seek here in this world. You want the best 
you can get from all-from the professional man; from the man in business-the best, and very best he has. The question is what do you want with this fellow, or that fellow? You want the best he has; so, when you become a friend of this fellow, you likewise demand and take away, and give a part, of the best there is in you."

"Yes," suggested Percy Field, "we are a part of all we meet-so may my friends be good, that I may have the greater opportunity."

"That's a part of the point," said Doc, as he appeared to reason deeper, while our friend Remus drew up closer and looked considerably as if he was going to say something.

"Now, why in the world can't we get acquainted with God in just such a way? In just such a way, who is it who has not been acquainted with their own mother, father, and although now that possibly the mother, father or friend, or companion, may be dead, why should we not still be able to live on in spirit with them -do you understand my proposition?"

"I don't know whether I understand your proposition, Doc, or not," put in our friend Remus, "but it appears to me that when a fellow is dead-and I don't want to be living with anybody and be dead-I want to be with people when thoroughly alive; and when I am gone I would prefer to be remembered as I was when alive. While here, I consider it my duty to play the game, and play it for all it is worth; and when I'm dead-oh, well, I'm dead, so what's the use."

"Well," says Doc, "I fear you do not understand me." And I fear I did not-and then the train rocked on, a cool draft blew into the window, and Doctor Leonard grew poetical, and gave the following reading: 


\section{"It Isn't Costly."}

"Does the grouch get richer quicker than the friendly sort of man?

Can the grumbler labor better than the cheerful fellow can?

Is the mean churlish neighbor any cleverer than the one Who shouts a glad "good morning," and then smiling passes on?

Just stop and think about it. Have you ever known or seen

A mean man who succeeded, just because he was so mean?

When you find a grouch with honors and with money in his pouch

You can bet he didn't win them just because he was a grouch.

Oh, you'll not be any poorer if you smile along your way

And your lot will not be harder for the kindly things you say.

Don't imagine you are wasting time for others that you spend.

You can rise to wealth and glory and still pause to be a friend."

"How do you like that, fellows?" inquired Doctor Leonard, with a smile.

"Well, my dear boys, I am not particularly a fiend about poctry, yet when $\Upsilon$ find something that expresses the idea exactly I don't mind using the words of an artist to convey my meaning. I have been thinking considerably about the brotherhood of man; and, as 
you have enjoyed the lines I have just read, let me read you another," urged the doctor as he cleared his throat.

\section{"What Did You Do?"}

"Did you give him a lift? He's a brother of man, And bearing about all the burden he can. Did you give him a smile? He was downcast and blue, And the smile would have helped him to battle it through.

Did you give him your hand? He was slipping downhill And the world, so I fancied, was using him ill.

Did you give him a word? Did you show him the road?

Or did you just let him go on with his load?

Did you help him along? He's a sinner like you, But the grasp of your hand might have carried him through.

Did you bid him good cheer? Just a word and a smile Were what he most needed, the last weary mile.

Do you know what he bore in that burden of cares That is every man's load and that sympathy shares? Did you try to find out what he needed from you? Or did you just leave it to him to battle it through? Do you know what it means to be losing the fight When a lift just in time might set everything right? Do you know what it means-just a clasp of your hand When a man's borne about all a man ought to stand? Did you ask what it was? Why the quivering lip, Or the glistening tears down the pale cheek slip? Were you brother of his when the time came to be? Did you offer to help him, or didn't you see? Don't you know it's the part of a brother of man To find what the grief is and help when you can? Did you stop when he asked you to give him a lift, 
Or were you so busy you left him shift? Oh, I know what you say may be true, But the test of your manhood is, what did you do? Did you reach out a hand? Did you find him the road? Or did you just let him go by with his load?"

This seemed to strike in the hearts of the Syndicate. "Did you reach out a hand? Did you find him the road? Or did you just let him go by with his load?" asked the doctor, expressing the sympathy of his very soul.

This reading met with the entire approval of the Syndicate, and increased and aroused the poetical interest to such an extent that Mr. Fred Segur suggested that we had a poet in our very midst, and urged that one Percy Field read, for the Syndicate, the rhythm story of the life of a lawyer.

"Oh, yes, Percy, come on with the poem," suggested Remus.

"Well," said Percy, "I do not recall at present the story of the lawyer, but, feeling that we are all interested in children, all of us having loved ones, who appear before our fancies as fairies of our keener appreciation, I will read you a poem, fresh from the pen, and maybe its youthful chime may bring refreshing sweetness to you in your thoughts of the dear children, who have, at times, gathered around your knees. Of course, you all know my little fairy, Percett. Her mother named the little girlie, nearly seven years ago, Margaret, but from the very beginning she has always $n$ red with me in the inner chamber of my soul, so I have called her Percett, and thus the reading I am about to give is entitled "My Fairy Percett." 
Here Mr. Segur drew near and put his hand back of his ear. Doctor Leonard and $\mathrm{Mr}$. Atwood pulled their chairs up close, while Percy meditated and then began:

"While in my office chair I was sitting, With such dignity as my state befitting, Unconsciously, to sleep I did fallA fairy visited me, that's all.

And as she stood before me with her childish look She asked me to read from a little dream book.

I read, and when I finished her fairy yarn, She nestled close, placed her head upon my arm.

(Then she put both her arms 'bout my neckSh-don't tell mother, I lov'd her 'bout a peck.)

She placed her lips close to my ear, Then I heard someone calling me dear;

She whisper'd a pretty secret, so none but I could hear-

Then the fairy kiss'd me and I whisper'd in her ear.

(Her eyes were blue, her love was true:

She was a fairy, thru and thru.)

'Little fairy,' I said-

She smiled and hid her head, And looked at me with her eyes of blue, Yet, I said, 'My dearie, who are you?'

And she said: do not worry or fretI come with a message from Percett. 'Percett,' says she, 'loves daddy very much!' Then I drew her so close our lips did touch. 
The pretty little fairy then hurried away, To whisper to another in just such a way.

There my dear little dream ended, And when I my dignity had mended, Decided to watch, and to hope, and pray, That the fairy might again come my way."

"A very sweet poem," was the comment of the Syndicate, while Mr. Segur added: "God bless the little dearies; how we love them." And then we finished our cigars.

From the smoking apartment we went to the observation end of the car. There we saw the rich farming lands of the Northwest. There were endless wheat fields, which appeared to be an ocean of golden, yellow grain. As we approached St. Paul we saw the great elevators, the mills, the Mississippi River in all of its grandeur. The weather, however, grew very cold, so it was hard to shiver and to appreciate the beauty of the surrounding. Doctor Leonard disposed of the cold weather very nicely by meeting a lady in the coach ahead. When he returned to the Syndicate he met the penetrating gaze of both Mr. Atwood and Mr. Segur, who proceeded to look both at and through him.

"Now, Doc," says Remus, with a twinkle of his winkable eye, "have you forgotten the agreement?"

"What agreement?" answered the Doctor, with a smile which gave some evidence that he had been thinking some about it all of the time.

"That I was to be known as Doctor, and you as merely Mister-" and then Doc smiled and so did Remus. Doc wanted to know what of it, and what was to be done about it. He thought little of his conduct as heing 
among the ladies seemed now to be a portion of his life. The affair, however, faded into the smiles of the various parties and no charges were preferred.

So in the course of the rocking and swaying we made ourselves ready for St. Paul, and in the meantime Doc and the balance of the Syndicate made a bet as to the time we would reach St. Paul. It was merely one of these "I'll bet you" bets-as we reached St. Paul at an hour of compromise, and being so glad to get off there, we all forgot about the bet and went our way rejoicing.

By this time it had grown so cold that an overcoat and winter wear would have been appropriate. I wore my Palm Beach clothes, with the apnearance of the last rose of summer. I had plenty of winter wear with me, yet I didn't feel disposed to change before night. I was very cold in St. Paul. Think of it. Cold in St. Paul, and the day bofore simply burnine up in Kansas City. Oh, what a difference a few hundred miles make.

At St. Paul, we first made our reservations on the night train for Walker. We procured thece lowers and three uppers. Mr. Atwood drew an upper and Doc Leonard a lower. Doc wanted to show the Syndicate that he was as young as ever, so, when the time came, he slipped away from Remus and went to bed in the upper berth.

Shortly after getting on the train, notwithstanding the fact that the heat was on, it nrew so cold that I had to put on my winter clothes. I made the change in the smoking car. After changing my clothes Mr. Remus came in and handed me a cigar, suggesting that it would do me a lot of good, besides helping me.

In a little while Mr. Segur and Doc came into the smoking car. Of course, we were talling of the fishing and various fish stories were offered. 
"Well," said Doc, as he smiled and looked at me, and then glanced around at first one member of the Synoicate and then the other, "there was a peculiar thing which happened while Fred, Clint and I were fishing up in this countiy several years ago. Fred was rowing the boat. I was fishing over one side of the boat when, whoopee, I got a dandy strike. Away went my line, and then I was reeling it in. The fish was darting first one way, then the other. Of course, at that time it was the rule, when one fellow got a strike, the others fishing in the boat would take up their lines, so as to give the one with a strike a fair chance. Clint and I were standing up in the boat. The fish had a firm hold on my hook and rushed first this way and that way. Finally I reeled him up close to the boat, and then away again he darted, and then back again, and under the boat he went-well," proceeded Doc, with a smile, "I thought that I had lost my fish, when all at once I found the fish lying in the boat just a flopping and a jumping, he having dived clear under the boat, and the momentum of his dart and the pull of the line having thrown him into the boat. So even in that extremity we had fish for dinner."

"Doc," said Mr. Remus, as he rolled his eyes about, and placed his hands in a prayerful position, "do you expect us to believe that?"

"Yes," says Doc, "just as true as if I am sitting here."

"Well," said Remus, as he appeared to be looking into the dim and distant future.

"Yes," says Fred, "that's true, but don't you remember what Mr. Grover Cleveland said about the word of a fisherman?" 
"Well, he said 'that one fisherman should never doubt the word of another fisherman,' they being bound together by the same common tie."

"Oh, no," said Remus, "far be it from doubting Doc's word, yet Percy and I are going fishing together, and maybe with his keen imagination and my ingenuity we might catch a fish in an interesting fashion. Just give us a chance-that's all we ask-of course, we believe you." Remus then placed his hands as if to pray, looked upward, and after rolling his eyes about, took a couple of puffs at his cigar. As the smoke arose to the ceiling he suggested that the fish just jumped into the boat.

"Why, that's nothing," said Doc, and Remus seeing another fish story on its way, looked more prayerful than before, and Doc proceeded:

"Now, this was told me by the biggest liar about Leech Lake. I have often heard him tell a number of good fish stories, and as Fred says, one fisherman should never doubt the word of another-this particular fisherman said that he was fishing down about Shingobee-he and a friend. They fished for about an hour and caught so many fish that they had to go to the short to unload for fear they would sink their boat. He said that when he got to shore and was taking care of the fish they backed a wagon up to the dock and that they filled the bed of the wagon. Then, as the wagon started off to the depot, the end gate came out and all the fish slipped out into the lake, so that's his name, I believe-says, 'Just wait a minute or so and we will catch 'em all back,' so out he throws his line, and in the course of a half hour had all the very fish back-filled the wagon and went on about their business." 
"And the second catch was right off the dock?"

"That's what I was told," vow'd Doc, "and so it must have been."

The rumble of the train brought sleep to Mr. Fred Segur, and he. haring fallen to sleep several times, and, naving almost fallen out of his chair as many, caused the sugoestion that we were to be pulled out of our nice warm berths at three a. m., so we went to bed.

In the meantime the berths had all been made. I rowed that I hall lower ton-the norter and all aboard vowed that I had lower three-so thinling that I would find my baggage in lower ten proceeded to look and see, and there I found someone who surgested that he had bought and paid for lower ten, and that he defied anyono-and his aroument sounded so much like the point of death that I took the the porter's word for it and climbed into lorwor three. Never before did the lights go out with such comfort as they did that night. I was tired-and slesny-and if someone didn't turn the hands of time un three hours I shall always think they did, for I remember going to bed and then it was all up for Walker.

\section{CHAPTER XI}

"All off for Walker!" was the cry of the trainmen at the early hour.

Each member of the Syndicate proceeded to count the heads of the Syndicate out loud, some of the members louder than the others, all forgetting that there were a number of nthers on board who had spent their money for a full night's sleep, and not the inquiry of 
whether Percy, Dan, Remus or any other member of the Syndicate were up and ready to get off.

We arrived at Walker at approximately three o'clock. We came, and then morning followed us into town. It appeared from the action of a number of the Syndicate-I will not mention any names for fear of calling particular attention to the various members of the Syndicate-that someone had placed a duty upon the Syndicate to awaken the sun. On this particular morning the whole Syndicate were several hours ahead of the sun and everybody else.

The crew of the train upon which we had entered Walker had placed our baggage on an outside truck, and puffed away, leaving us alone. Walker was thoroughly asleep, yet somebody was in town-and who that somebody was, well, Mr. Walker, the people of Walker, the dock man, the boat man, station agent, and all, didn't seem to appear disturbed, for on they slept, notwithstanding the fact, however, that they had been duly notified of our arrival and the time thereof.

There was one member-and I will not mention his name, either, for in this act or suggestion of sensibility he may be coveted-surgested that we go to the hotel and get beds for fifty cents apiece and finish out the rest of the night, as it was his belief that we wouldn't be able to get ham and erg's before eight o'clock in the morning.

"Oh, my goodness, no!" shouted Fred. "Let us slip into our rough ciothes, move our baggage to the dock, and when that is done we can then have breakfast, and then our boats will be ready and then we'll have an early start."

"All right," said everybody. Somebody again suggested that he didn't believe the boatman would think 
us foolish enough to keep our appointed date, and that our early start would be about ten o'clock, yet all the Syndicate to a man slipped around behind the truck, found his trunk, fished out his heavy clothing, and in a few minutes all the baggage was on the dock-but the boatman, where was the boatman? Where was the captain? Well, when I think of his cherry faceand while he was a captain, and very fond of water, the color of his nose didn't so indicate-and consider his habits to be like another member of our party, who enjoyed sleen, I can well imagine what the captain was doing at three thirty a. m.- so back to the depot we went.

There was the same old depot-cold, barren of all earthly joys. It was the cold gray dawn of the morning. When I say cold. I mean it. The trunks, which were far from light, had been carried to the dock, on an empty stomach. I am sincere when I say an empty stomach is a very poor truck. There we stood, acclimated to a hundred in the shade, hungry, araiting the time, and now with a considerable impatience, when we might coax the boy in the ravtaunt to build a fire in his stove and serve us with something.

In the meantime Remus decided that his motor must have been shipped over the other railroad, which had a station about a mile from town on a full stomach, and ten miles on an empty one. so down to the station we tramped, and found the said station securely locked and bolted, with the shades drawn-bearing much the resemblanse of a deserted house. Back we went to town, but not civilization, as we don't generally have civilization until a more civil hour.

After we reached Walker again we saw the sun a-peeping up on the east horizon. 4 beautiful sunvise- 
but as far as the beauty of that sunrise is concerned, there is no living individual of Northern nativity in and about Walker who saw or appreciated the sunrise that morning. This pleasure was for the Syndicate alone. On the truck on the depot platform we sat and enjoyed the dawn of the morning, while Fred suggested that he couldn't understand why it was that the boatman was not up to meet us, as he had given e-x-p-l-i-c-i-t orders of the day and date of our arrival.

The sun grew higher and higher, yet no one stirred in Walker, except the Syndicate. Finally by seven thirty, or a quarter to eight, there was a stir about the restaurant across the tracks. The Syndicate went over and proceeded to order as was customary with them in Missouri, but breakfast was not ready, and they could order, and order, and reorder, but there was a time for everything, and it was not as yet breakfast time in Walker.

We put in our order, however, and in the course of an hour were served a very inferior breakfast. Yet we did appreciate it and went our way rejoicing.

After standing around for another hour or so an important looking individual arrived at the dock. In a little while we discovered that he was in charge and the man with whom Fred had communicated.

"Well," says Mr. Segur, looking quite firm, "didn't you get my letters?"

Mr. Billban, as that is what he was called, rubbed his chin and intimated that he had received Fred's letter, but frankly stated that while he had been informed in the letters that the Syndicate would arrive at the hour and date upon which we did arrive, that he didn't expect us until the next day; that he had almost rented our boats to somebody else, expecting us later; 
that he wasn't quite prepared for us, and had he expected us at the time we arrived everything would have been ready, etc., etc., yet he didn't expect us so soonbut be that as it may, he suggested that the boats could be let to us today, just as well as the day he expected, and that there was one of the boats, and here was another-

"The supplies-groceries!" demanded Fred, looking slightly vexed.

"Yes," says Mr. Billban, "we have them all ready-"

"Where are they?" again demanded Mr. Segur.

"Oh, yes," says Billban, "they are locked up in the station," and then we woke up the station agent and half of the town and lifted them down to the dockloaded our boats.

As we sailed out of the harbor, bound for Kabekona Bay-in the words of the old colored man- "it sho' wuz da middle ob da day."

The Syndicate was afloat in the cold and clear water of Leech Lake. The sunshine of the middle of the day felt very comforting, and it drove away the shivers of the cold gray dawn. Fred was seated in the forepart of a launch, drinking water out of the lake from a cup and looking mighty satisfied with himself and the world at large.

Of course, to our left, while headed toward our camping ground, lay the points and promontories of more or less interest and beauty. Among them, first on the left, traveling toward Kabekona, a point of land which extends so far out into the lake that it most becomes an island. This point stands high and alone. It is beautifully wooded. It is inhabited with what is known in this northland country as summer people, who live in a very comfortably looking log house, which 
faces the lake. As our boats passed on we came in view of what is commonly called Glenary. This is a summer place; and upon this point stands a summer hotel, where a number of the summer people live who come to look at the lake, and to occasionally fish in it. As our boats passed on our view was taken with a modernly developed summer place-Morris Point. This is one of the many beautiful points of the lake. Mr. Morris, of the packing company, is the owner, and has spent a considerable money upon its improvement. $\mathrm{He}$ generally keeps a light burning on this point at night so that the travelers may know their whereabouts. This point stands at a position about half way to our camp on Kabekona Bay. We passed it and upon inspection found everything to be just as we had left it.

The railroad bridge of the Great Northern Railway appeared before us. This bridge spans the inlet to Kabekona Bay. It is hidden in a way by a promontory of land which runs away out into the lake and makes it necessary that a traveler from Walker go a considerable distance further north and east in order to make his entrance into the bay. This entrance is generally filled, to some extent, with deadheads, and in at least two places you can find, most any night, a floating bog. After passing under the railroad bridge you come into full view of Kabekona Bay. Immediately, upon entering this bay, it appears that you have dropped into a wild land. There is nothing particular ahead of you but water and a shore line, which is covered with a dense growth of trees of the Northern clime.

About two miles ahead and to the left stands an old square box of a house. It never was painted, and prob- 
ably never will be. It has all appearance of being used at one time, and a good many years ago, as a bunk and grub house for the lumber jacks, who at one time infested this particular shore of the bay. Civilization has cut away a few acres here, and this clearing stands in blue grass. There are a few big trees left.

As we approached our camping ground we found that the ice and storm of the winter before had taken out the dock we had labored the year before to make, so we landed at the best place we could find.

We found, upon landing and a short tour of inspection, a few slight changes in the place, and that Mr. Billban had unloaded the major portion of our baggage. He, at the particular time, was wrestling with a large barrel of gasoline, when, much to our excitement, the barrel slipped off of his boat and into the lake. Some of us were surprised to see that the tank floated, and that the gasoline was brought into shore without injury. Mr. Billban now started his motor and hurried away, leaving the Syndicate to hustle for itself; and hustle we did, and had to.

Our breakfast had most been forgotten-yet our dinner was a long ways ahead of us. We took a look over the place and found the old grub-house to be in about the same run-down condition, excepting, however, for its roof, and that really looked as though it would tumble in any minute, having been broken in the middle by having too much snow fall upon it last winter. The carpenters of the Syndicate lended a hand and shortly the roof was put in a condition, which condition, while being safe, was not much upon looks.

We found that the screen door had been taken from the grub-house and proceeded to make something else do, so Remus, Percy and Dan took a door off of a tent 


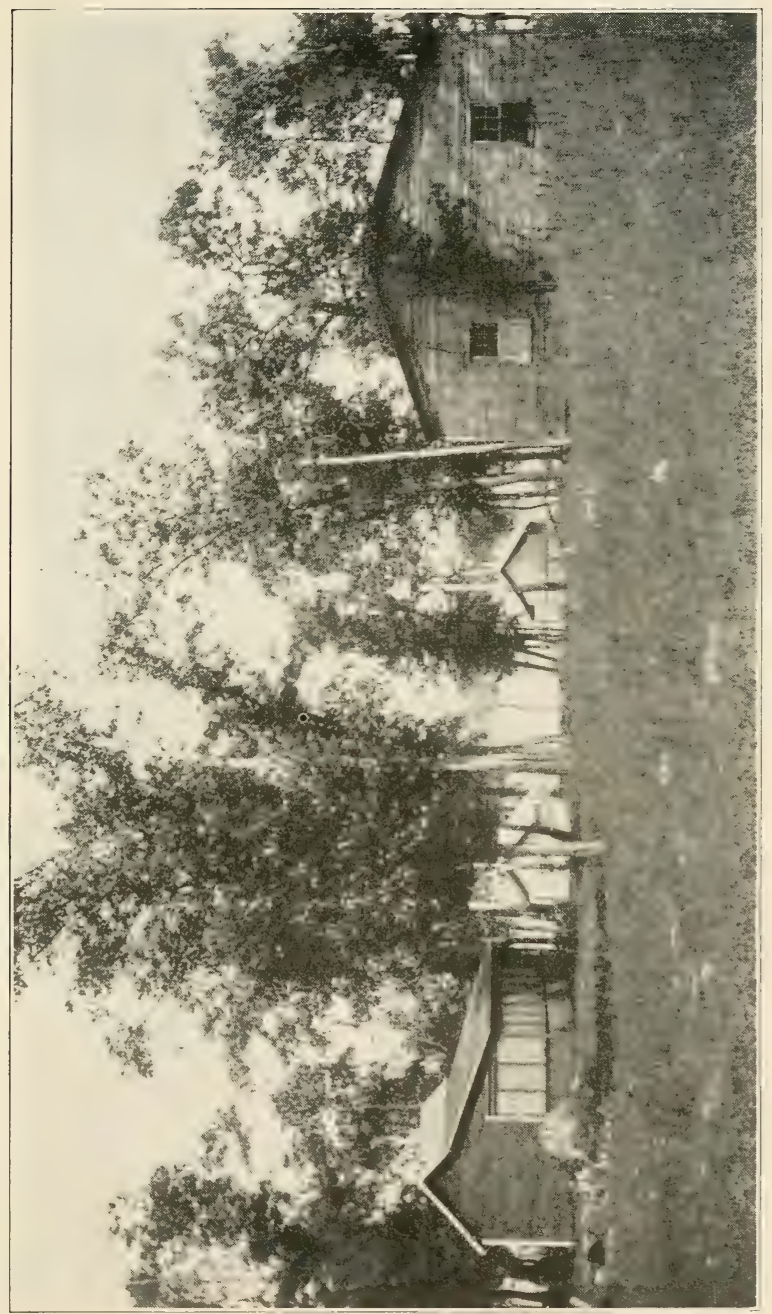

A
O
0
0
0
0 
and put an extension upon the house and made the house fit the door, and in that way provided ourselves with protection against the mosquitoes.

While these members of the Syndicate were doing this the balance swept out, washed and dried the dishes and cooking utensils. Mr. Stephenson prepared a pile of dry wood. Our beds were made in a sort of a summer-house, upon its porch.

Doc, Fred and Clint brought a hale of hay with them, and in due time I found the purpose of the hay. They also brought a bed tick with them, stuffed the tick with the hay and prepared a bed for themselvesand so did everybody else.

After everything in the way of preparedness was done, the cooks, Doc, Remus and Percy, proceeded to fix a dinner. This was the first real good feed we had had for several hours. After the customary pipe of tobacco by those who smoked, a customary glance, by those who enjoyed reading, at the Ladies' Home Journal, or something else of the kind, Mr. Segur waded into the dishes, and with the assistance of all, soon ran out of a job.

The Syndicate being out of a job, and having had a real good meal, and it still being Sunday, and it being against the religion of certain members of the Syndicate to fish on the Sabbath-of course the fishing reels, hooks and bait all being gotten ready for the following day, without exception to day or religion, the Syndicate discovered that they did not have the necessary qualification to lawfully fish in the lake-to Walker the Syndicate must go.

Oh, will I ever forget how tired I was when somebody suggested that we go to Walker-and so was everybody else, but to Walker we must go. 
It was Sunday night, Walker was dressed up a considerable, yet, into Walker went the Syndicate in their fishing clothes-a veritable bunch of Indians, and to look at them would be to form some doubts as to their being civilized. Yet the people at Walker welcomed us as though we were their lost children, and with a successful voyage down we hurried to the hotel, where we found an emissary of the deputy game warden, and there procured our licenses. These licenses cost a dollar apiece. We completed our purchase, and then the people of Walker looked us over; and, indeed, we were some tired looking tramps. Several of us bummed stationery off the hotel and wrote our first letter to our wives.

It was fast growing late, and it was dark on the water. Everybody was in a hurry. I jumped in, started the motor, and away we pulled, when the darned old engine missed and coughed, and then it was crank, and crank. I cranked until my hands were all worn to the quick, and it wouldn't go. During all of this time Mr. Segur looked profound-he called attention to this "do-dad" and that "do-dad," offered all kinds of suggestions.

Finally, we found that the gasoline had been turned off in the head of the boat. This, of course, was remedied, and away we went, leaving Walker and our ruffled dispositions behind. I do not remember the exact number of guides we had in the launch on that trip, but each and every one signaled in a different direction to the other, and finally, after sitting all cocked up like a trigger on an old-fashioned rifle for a couple of hours, arrived at the camp.

Shortly everything was quiet in and about the camp excepting for the buzz buzz of the sleepers. I didn't 
have time for anything, after tying up the boats and pulling them in, but to get ready for bed.

The air was cold and fresh. We had lived from August to a night in the early portion of November, as far as the climate was concerned, without touching on any of the other interceding temperatures. When I pulled off my heavy winter wear, outdoors, and slipped into a night shirt, I feel that you will believe me when I say that the air was a trifle fresh; yet after tucking one's self into the blankets and a sleeping bag-it is easy to appreciate the condition which prevailed over all.

\section{CHAPTER XII}

There was one member of the Syndicate stated that he started to say the Lord's Prayer before going to sleep, but that when he had said "Our Father," he ceased to remember. Shortly thereafter, by time and tide, clock and watch, four a. m., a sonorous voice of some member was heard.

"Oh, my goodness! I just can't lie a-bed any longer. I've tried it, but can't do it any longer," shouted somebody, who, having shouted it for his own benefit at least once or twice, proceeded to shout it a second, third or fourth time for the benefit of those who could sleep.

There were a number of the Syndicate who lazily stretched themselves. We had nothing to do in particular, and yet everything seemed to depend upon hustling out at the early hour.

I have often heard that the early bird catches the worm, yet never do I believe that the early worm catches 
the only fish, for, in our experience, most of the fish were caught somewhere near the middle of the day, sometimes late in the evening, but none that I remember of early in the morning.

Yet the Syndicate had been stirred at the hour of four a. m. It might have been, however, that the Syndicate to a man desired to get up at that hour-and that the Syndicate to a man "couldn't lie a-bed a minute longer"; and it might have been that a certain member of the Syndicate couldn't under the circumstances; and it might have been that a certain member of the Syndicate desired to maintain a reputation at being an early bird, or had a reputation to maintain; or it might have been that a certain member of the Syndicate was at that hour awake, and would not in his present fatigued condition trust himself in a warm bed, out in the cool, crisp air, to again fall asleep; yet, laying aside all of the various possibilities and probabilities, there was the Syndicate thoroughly aroused at the early hour, at a time when sleeping arpeared not only the greatest of all delights but very helpful indeed.

At any rate, as suggested, one of the members of the Syndicate, for various reasons, could not permit himself to sleep any longer, so he and Clint got into an altercation concerning a dip in the cool, limpid waters of the lake. The altercation ripened into a banter. Of course with a banter there always springs a lot of loud talking, which is generally coupled with slowness of action; yet neither of the boys would be bantered, so into the lake they plunged; then followed noises, shudders, shivers, and expressions of both great pain and great joy. I thought that I had a few moments or at least a half hour for a nap, as a fellow who really loves to swim can't enjoy himself in less time, but my old iron bed began to shake and vibrate so with the expres- 
sions of a watery death that sleep I could not, so I slipped into my clothes, hurried to the grub house and started breakfast, leaving Doc, Fred and Clint to settle the question that the early morning was the time for "a man" to go in swimming.

Of course, it might have been, yet I enjoy swimming very much, and to do anything I enjoy I want plenty of time, a strong body, and, especially, a well nourished disposition. I don't believe anybody who enjoys swimming could get the most out of it at four a. m. At any rate I didn't try, but put forward my efforts toward getting breakfast.

I had started a large pot of oatmeal to cook the evening before. I had been told emphatically by a member of the Syndicate that it was twice too much, but, measuring the appetites of the Syndicate by my own, found it quite agreeable.

"How much oatmeal," said I to a prominent member of the Syndicate, with a wink at another distinguished member, "would you like for breakfast?"

"Oh, just a little-I do not care for very much-you have cooked twice too much."

So just a little was apportioned out and placed at the seat the said member of the Syndicate had occupied the night before, and before each of the other chairs I placed a bountiful portion. I was still serving the oatmeal when all were seated, but to my surprise I found there had been a shifting in the seating of the various members of the Syndicate, so I smiled to myself and leaned over the vacant chair and filled the bowl, much to the comfort of the server and his appetite.

We also had an abundant portion of bacon and eggs, and this, together with a like portion of cakes, made a reasonably good breakfast. The Syndicate, to a man, was well satisfied. 
After breakfast each member seemed so contented that he preferred for some moments to sit and reflect, or smoke a pipe, excepting Remus, who was busy packing a box for a shore dinner. He did this so quietly that for some time he was not discovered doing anything. Everybody else seemed busily engaged.

"Well," said Fred, as he got up from his comfortable seat and tramped noisily around the grub house, with such a heavy trearl that the roof most did fall in, "if no one will wash the dishes, I'll do it." So it seemed that no one would, and that Fred did, with the aid of Clint, who, alone, came to the rescue.

As the dish-washing progressed I found that Remus needed assistance in the packing of the box. A list of everything we would need was made. I called the list back to Remus, and everybody else, so that nothing would be omitted. Remus checked every item, and then, with a confidential wink, suggested that he had left out at least three articles, which, being then put in, the box was full and complete.

These supplies were taken from the order placed by Fred--and right here I want to thank Mr. Segur on behalf of the Syndicate for his painstaking canvass of our needs, as nothing was missing from his order.

A general preparation followed of the boats. Dan loaded up the various gasoline cans, and mixed the oil with the gasoline in the exact proportion. In a little while the boats were loaded with supplies and everything necessary for a day's fishing trip.

"Where shall we go?" everybody suggested.

Nobody seemed to have any particularly definite plan as to the place or point, yet we were thoroughly prepared and go some place the Syndicate must. Everybody seemed to have a perfect understanding as to where to go, and yet, I dare say, no one knew exactly. 
"I suggest," said Fred, in a sonorous voice, such as would command the attention of everybody except the Syndicate, "that we fish in the bay."

"Yes," says Doc, as he proceeded to get into his boat. "Boys, we'll fish in the bay."

Everybody seemed to understand what was meant by fishing in the bay, and everybody pulled out for a different bay, and yet everybody agreed with Fred to fish in the bay and struck out for the bay. Some were bound for Shingobee, others for some other bay, while the other boat for the bay in and about Onigum, and, having no place in particular to go, we went over to the bay directly across that arm of the big lake which extends between Walker and Squaw Point.

Fred and I were in the launch; Clint and Doc were in the smaller motor boat; Remus and Dan having another boat. The boat which Dan was driving had considerable more speed than any of the other boats, so it dashed about quite playfully. The waves were rolling pretty high and in time we were so separated that none of us could see the other.

I suggested to Fred that we had better go back and look for the other boats. Mr. Segur said he thought, as Dan was not feeling well, Remus and Dan had possibly gone back and were going to spend the day about camp.

In the course of an hour's fishing we sighted Doc's boat, and, after hailing them, suggested that we prepare dinner. I urged again that we had better look for Dan and Mr. Atwood, but Doc said that Dan wasn't feeling well and he felt positively that Remus and Dan were at camp. So we unloaded our grub box, built a fire and prepared a shore dinner. We had caught a number of pickerel but no pike. We didn't have any fish for dinner. 
Doc and Clint cooked the dinner, and, there not being: anything particular for me to do, I took a swim in the lake.

The water was cold and fresh. After preparing myself for the swim and starting to go into the cold water by degrees, Fred, not having anything to do, and having gone swimming at four a. m., busied himself by standing on the bank, throwing stones at me and splashing me with cold water, until I got into deep water and swam away from him.

After a good swim I was ready for dinner, and so was everybody. Neither Remus nor Dan were there. We missed them. I couldn't concede that they were back at camp, yet Doc and Fred affirmed their whereabouts with such positiveness that I let the matter drop.

We spent the rest of the evening trolling for pike, but caught a lot of pickerel. At five-thirty p. m. we headed towards camp, and in due time arrived.

When we reached there, we found Remus and Dan. This time we found Mr. Atwood in a disposition which was not altogether in keeping with his general character. He was not such a merry-faced man. He looked a little grave. Doc asked about Dan. Dan was in reasonably good physical condition, yet he, too, looked a little stern. In the course of a very little while we heard that the engine in Dan's boat had gone dead, and the wind and waves had driven their boat across the lake, over to Squaw Point, where they had spent the day endeavoring to fix the engine, without the tools or parts necessary, which had been put into the other boat. The points of the spark plug had heated and melted together. They could not find a simple little wrench of any kind to take out the spark plug to separate the points. There was nothing but waves, and weeds and shallows, and the wind too strong to row back to camp, 
so they had to lay adrift all day in the waves, while the rest of the Syndicate fished. After great labor, and tossing, they were able to land, and, after walking a long ways, stopped at an Indian hut. There inquiry was made for a wrench, but the Indians couldn't talk English. After much explaining, something was found that served the purpose and the spark plug was removed, repaired, and the two shipwrecked fishermen started for home.

"And the worst part of it, in my endeavor to fix the engine," said Remus, as he gave a very serious smile, "all of my tobacco fell into the lake. There we lay, a-bobbing like a cork, all day long. Dan was sick. We had a deuce of a time; you can imagine how we felt." We all did, and all apologized, most profusely, including Doc and Mr. Segur, resolving never again to be out of sight of any of the party.

During the profusion of apologies we cooked a very fine supper. Clint furnished the wood, Fred set the table and P. Field, as sometimes he was called, performed the duties of chef, everyborly working to the satisfaction of everybody else.

I sat down to smoke my pipe before going to bed, as it was growing late.

"Well," says Fied, restless to do something, other than wash the dishes, "if I was to go to town, I am sure I would have a letter from my honey."

"And so might I," was the response, given by a tired fisherman named Percy, and in no shorter time than it took to tell of it the bargain was sealed. I was to drive the launch anil we were going to Walker at night for a letter from Fred's honey and my darling.

It was very clark on the water. I looked out toward the end of Kabekona Bay. There was the wild and dark shore line. I was very tired, yet I started the en- 
gine and in a little while we were sailing for a light speck on the holizon. We made the railroad bridge with safety and the big lake. It seemed like everything disappeared when we got into the big lake. The waves were rolling a monotonous churn, and every now and then a big one would spill its white whiskers into our boat. On we went in our quest. Fred sat in the front of the boat and gave directions and drank water out of the lake.

After rounding Morris Point we had no difficulty in locating Walker, from the lights on the dock, which looked most like stars on the horizon. Gradually they grew into lights, yet as they grew stronger our eyes we $:$ dimmed and the blackness about seemed impenetrable.

"Keep a sharp lookout," said I, as it was so dark that I could not see much over the front end of the launch.

"All right!" responded Fred, and on we went.

"What's the green light to our left?" I inquired of the lookout.

"It must be a boat," answered Fred.

It looked to me as if it was going from us. We had loft in such a hurry that we had no light. I again urged Fred to keep a sharp lookout, as I felt most anything might happen on such a dark night.

The green light disappeared and all was dark except for the lights of Walker. We were within a quarter of a mile of the dock. The lookout anpeared at his usual position. His face was turned toward the dock.

"Where shall we land?" I demanded, and was surprised to hear no response.

"Look out-Segur, an oar-push away!" And no resnonse was made by the lookout. At that very moment a huge launch appeared from the blackness. It had no light. It was steaming directly toward us. I threw 
the rudder clear over and jumped to the middle of the boat, grabbed hold of the prow of the big boat and pushed with all my might. Never before did I appreciate being active and strong, for, as I leaned against the big boat and thus eased the momentum of striking: our boat, our launch responded, so that I pushed it clear of the big boat and saved being run down and a cold dive and swim.

"Hey, there! You most turned the boat over," shouted the lookout, and then he turned and saw the big boat steaming by, and shuddered.

"Oh, my goodness!" said he, as we landed and went for a letter from our sweethearts.

Upon reaching town we found that the postoffice was closed, as well as everything else, excepting a tobacco store, where we purchased three boxes of "Lucky Strike"-and also at the grocery store three loaves of bread. This was the extent of our purchases and conquests in Walker--for which we had risked our lives on the deep, cold, black water's of the big lake.

After our extensive concuests, we hurried back to the dock for a start home. We got into the launch. I took my place at the engine, and Fred agreed to keep a sharp lookout. I primed the engine. Its compression was good. "All right, push off," said I. Off we went, but the engine only coughed and then the waves took us for a drift. I made a number of inquiries about the gasoline being off, and was informed that it was on. It was, and, after draining the carburetor in the dark and most falling into the lake, I gave it a good jerk and away we went for home.

Fred was a good guide this time and steered us straight to the railroad bridge and to camp. I never did know just how he did it, but we arrived safely. 
The Syndicate had put a light on the shore, as a signal to us of the landing place, and were there to meet us and help land the boat. This being done, and the news of a certainty that there would be a railroad strike being given to the crowd, we tucked ourselves in for the night.

Never did a bed feel so good to me. Before this there was one good thing happened, and one good rule adopted, and that was that everybody was to be up the next day as late as six o'clock in the morning. I never had any particular liking or disliking for getting: up at six o'clock in the morning, but as that was a normal hour I decided that I was with the balance of the Syndicate and ererybody up as late as six o'clock.

\section{CHAPTER XIII.}

Everything was peaceful and quiet about the camp on the morning of August 15th, 1916, until the hour of five-fifty a. m., and then the storm broke.

Fred and Clint were again bantering about going swimming, and, after the usual amount of noise, the two of them struck out for the lake. A repetition of the shrieks of a watery death followed.

At six o'clock sharp I was up, dressed and had the fire going.

"Who's for bacon and eggs?" I inquired of everybody. Nobody seemed to want eggs.

"All right," said I. "I'll just cook some for myself, as nobody wants eggs."

"Now, Percy," said Fred, a little puzzled, as he smiled, "of course, if everybody wants eggs, I'll take some, too." He meant two all the time, and so did 
the balance of the Syndicate, as that was the portion I prepared.

Of course we had another pot of oatmeal, plenty of bacon, two or three eggs apiece, wheat cakes and coffee, and real cream, for those who liked cream, in their coffee and oatmeal.

Clint packed the box for the shore dinner and Remus and Doc washed the dishes. During the dishwashing period I don't know what had become of Fred and Percy. They didn't have anything exactly to do, and there wasn't any reason given as to why they were not on hand, but they were absent.

"Where shall we go today?" everybody inquired. Somebody suggested Lake Benedict. We were to go to Lake Benedict, camp at the extreme end, and drink from the cold spring. The boats were loaded much in the same fashion as before.

We motored to the extreme end of Kabekona Bay, and there found a small, weedy inlet to what is known as Lake Benedict.

This is a beautiful body of cold water, very cold water. It is said that this lake is fed by cold springs which come from the bottom of Lake Superior. This lake is much the shape of a big egg. It has a great many miles of shore line, which gives the appearance of a veritable wilderness. We drove our boats to the extreme end, and went to look for the spring. The lake had been so filled and flooded that it was out in the lake, so we had to content ourselves with drinking from the lake.

On our way to this beautiful lake Doc gets to philosophizing, and in the course of his conversation Clint puts in and also Mr. Segur. 
"Yes," says Doc, "suffering is not always the worst thing in the world. We all have more or less to suffer for our fellow-beings-there is the home, the greatest of all institutions. In order that our home should be complete, there often necessitates a considerable suffering. Sometimes it is the mission, or apparently the mission, in life of some folk to suffer-"

"Doc," said Clint, "of course it appears that some should suffer, and a great many do," and then he lit his corn cob pipe, threw out a little more line and winked at Percy Field. "It strikes me that it shouldn't be anybody's mission to suffer."

"My notion," puts in Percy Field, "is that it is everybody's mission to be happy, and under all circumstances."

"Doc," interrupts Clint, "speaking of suffering and happiness, what do you think of the divorce question? I'd like to hear your views on the subject, and yours, too, Fred and Percy."

Mr. Segur looked very grave. The divorce question was a divorce evil, and he stated that he was against it. Dead against it-didn't believe in it at all; it was all wrong.

"Of course Percy, being a lawyer," added Mr. Segur, "is bound to believe more or less in it."

"No," demanded Percy Field, "not because I am a lawyer-I believe in it because I believe we should be humane in our dealings with human beings, and especially our weaker brother and sister."

"Well, Doc," urged Clint, "you have had a great deal of experience, let us hear from you-you are quiet in this regard-you are in favor of it?"

"Let me put a question to you all-it is this: Suppose a man has married a woman and the woman turns out to be totally unfit to be a wife; or, on the other 
hand, suppose a woman marries a man and later on it turns out that the man is totally unfit to be a husband -in that sort of a case what should either party do in order that they may endeavor to be happy and obtain the things which life really intended for them?"

Mr. Segur looked very grave, and took a deep drink out of the lake.

"What should he or she do?" demanded Clint, with a wink, realizing that he had put a hard question.

"Well," said Mr. Segur, "I cannot imagine a case where a woman would be totally unfit to be a wife-but maybe I can a man-and, of course, where the man is totally unfit to be a husband, in that extreme caseand he would have to be absolutely totally unfit to be a husband-a divorce should be granted the woman."

"Then," said Clint, with a smile, "you do believe in divorce?"

"Only in the most extreme case imaginable," replied Mr. Segur, firmly.

"Now, Doc, tell us your version of the matter."

"Well, in this regard it appears to me that for the good of society it might be that it would be far better for a man or woman in those extreme cases to suffer from the total unfitness of their mate in order that society may be purged of divorce. We are all put here for a purpose; it may be that the purpose of the unfortunate mate be that he or she should suffer."

"Now, Mr. Lawyer, tell us your version," stated Clint. "My version is that we all should so live that each should make his or her mate happy. If that condition would exist there would never be an occasion for a divorce; yet, realizing the frailty of humanity, all of us are bound, either by environment or choice, to do wrong, to do good, or be happy. If we fail to do good, and fail to make the lives of our mates happy, misery, hate and 
unhappiness follow; and, as my notion of life is to be happy, to do good, so, with failure on the part of the marriage contract, both morally and civilly-my notion is that even the weaker brother or sister should be given another chance. Divorce has come to us with progress-it is the result of progress. It may be that some of our states make laws which make the obtaining of divorce too easy, and some too severe; yet, in the majority of cases, where the lesser ground is set forth, there also exists a greater ground, or a larger or deeper wrong-and that, for the sake of humanity, or the moral effect, the lesser ground is advertised. The wrongdoer should be punished-and, as far as that is concerned, they all are. You don't have to pass a law that a man should be hung or put in jail for a wrong, and he or she may escape all outward punishment; yet he or she if they do wrong shall receive their punishment. I believe in teaching people to live right, to do right, and be men and women, and when that condition exists, then we will not be troubled with the divorce question."

"Yes," says Doc, "that is an idea-Oh, how good it is to associate with each other in this way, to have and receive the various opinions upon different thingsthere wouldn't be any fun if we agreed on all things; that's the beauty of real companionship."

At this point Fred took another drink out of the lake, Clint thought he had a bite, and grew impatient to draw out a big one; yet, much to our surprise, we found that our hooks had fouled and were dragging on the bottom.

As we pulled in our hooks, we decided that we should make camp for dinner.

We landed at the extreme end of Lake Benedict. It was a beautiful place. There were great Norway pines, white pines, and trees of most every Northern variety. 
The underbrush near the shore was not thick. It appeared to have been cleared, and a nice bed of bluegrass had sprung up in the wild. We made our fire and started dinner. Two nice pike had been caught in the bay, and we prepared them. We had a dandy shore dinner.

About the time we had finished our dinner we heard someone coming out of the woods. We discovered a boat not far away. A man and a woman emerged from the thicket. They were laughing and talking, both carrying a milk bucket, and making their way to their boat.

"Hello, there!" says Doc, and he, taking a look into the buckets, saw that they were filled with wild blueberries. "Come and take dinner with us-we'll trade fish for blueberries-or can't we buy some?"

"We've had dinner, thank you, in the woods," said the woman. She smiled and turned a sunburnt face towards us. Her eyes were blue, and by looking at them you could see she was pure of heart. She was a brownhaired woman, dressed in khaki clothes-a typical sunkissed berry of the Northern woods. Her husband was tall, well nourished, a man of pleasing address.

"If you want some blueberries to eat we can let you have some," said he, as he drew near and showed his prize bucket.

"They've been a heap of trouble to gather, yet they are mighty good," said she, and then she smiled, a real healthy smile.

"Oh," said Doc, "if you won't take dinner with us, how much should we pay you for these berries?" as he proceeded to dish out enough for each member to have a plenty of the wild dessert.

"I think twenty cents would be quite enough for what you have, if you take some for supper." And so we 
did, and then they told us that they lived over on the other side of the lake, and if we would go back into the wood we could gather all we wanted.

They then said good-bye and went away.

As they went away I recalled our conversation about divorce. There were two people who lived away from the world, in a small house in the wilds. Her husband was a worker; she, too, was a worker. They were together in God's out-of-doors, playmates, helpmates, gathering blueberries together, and with them the jewels of life. Divorce! What cared they for the laws of divorce, its grounds-its lesser grounds, its greater grounds-for they were happy, and so should we all be.

After dinner Dan, Remus, Doc, Clint and I took a swim in the cold water of Lake Benedict. Mr. Segur maintained that he had been swimming when the "men" go swimming, and contented himself with drinking water and throwing stones near some of the bathers who were reluctant about taking the first plunge.

There, in that far away place, we had a happy time. The water was cold, yet by exercising we all were comfortable.

In the course of a half hour Fred grew restless and proposed fishing. We all dressed. As the place was so beautiful, I preferred to remain underneath the big trees and enjoy looking at the wilds. So it was agreed that I could stay and meet the Syndicate at six o'clock at the inlet to Kabekona Bay.

The other boats were filled. In a little while they motored out of sight. I made myself comfortable by leaning up against a great pine tree. Oh, how beautiful! The air was cool and refreshing. It was filled with perfume of the pine branches and the woods. The sky was blue. A few white clouds appeared as if painted on the far away horizon. Everything was still, 
excepting for the call of a wild goose to its mate; and then a loon. Then two wild ducks flew up close to where we had camped. They appeared to enjoy fishing and swimming. They dived, flopped their wings, and spent an hour or so in my presence. Then came flying a large pelican. He flew about for quite a while and rested his long legs some distance from me. Then a drove of wild ducks flew over me, and I noticed in the distance another drove, and then a drove of mudhens. They alighted in the water and swam about. Oh, how wonderful these people of the wild! How wonderful the wild! I have often heard its call. How often, too, have I, in a way, envied the wild duck; the wild goose, who, by the mere flopping of wings, could breakfast in the sunny Southland and supper in the cool waters of the North.

I awoke from my sweet dream of nature, and saw the sun was sinking fast, packed the boat, started the engine and motored for the inlet.

On my way I saw my friends, Remus and Dan, coming to meet me. There was Remus, with his happy smile, and Dan, with his hand on the wheel, delighting in encircling me, and, with his speedy motor, running rings around me.

Fred got into my boat to help steer through the crooked inlet, and away we motored. I felt so good, so rested; so free from trouble, strife, care, and worry, that I sang a few songs on our way to camp.

We arrived at camp in due time. Everything was just as we had left it, and soon the stove was going, potatoes were boiling and rutabagas, too; a salad of tomatoes and cucumbers was being prepared; fish, nice fresh fish, frying. Percy Field was standing over the stove, being sprinkled from time to time with hot grease. In the course of a little while, the table having 
been set by Fred, and the roof of the house almost knocked down by his heavy tramping, supper was served.

Everybody was ready for supper, and supper, and a plenty of it, was ready for everybody. After the course of a few moments spent in eating, and some serving, Fred took a big drink of tea and then smiled.

"Well," said Fred, "that's a good one on Remus-ha, ha! He's a good one to pack the lunch box-left out the frying pan!" And then everybody took a jab at our merry-faced man, who proceeded to take a jab at all concerned.

"Be it resolved," said Remus, with a smile, "that this is a frank bunch-and if you don't do to suit them, they'll always let you know about it - and be it further resolved that this bunch, being frank, can do all the things they do not appreciate others doing."

"Now, Remus," says Doc, in a pacifying tone, "we got our fish fried very nicely in a piepan. It was really better to have forgotten the frying pan, as it rather taught us to shift for ourselves in an emergency."

"And we shifted," said Clint, who had finished his dinner, pushed his chair back and started his pipe, "but it was rather hard on the piepans and another such caper will cause somebody to be short a plate-I won't say who," and then Clint winked very knowingly at Percy, took a long puff at his pipe, seconded Mr. Atwood's resolution, which was immediately put in effect.

Everything was perfectly quiet for about a minute, and then Fred discovered something was wrong with the table and almost knocked the lamp over in trying to take the cloth off without removing the lamp. Then the table had to be taken apart and put together, or fixed. Dan had to come to the rescue, get this, that and a screwdriver, help take it apart, by lying on the 
flat of his back underneath the table, twisting and squirming, and doing this to that "do-dad," as Mr. Segus expressed it-and finally the whole bunch succeeded in putting the whole table back in a position very similar to its original condition.

"My," said I to myself, "that Fred Segur certainly must have been a regular boy." And so he is now.

Finally the table got so it would stand on two legs and rock on the other two, yet at all events maintain its equilibrium.

"Where are we going tomorrow?" demanded Remus, in a voice intended for Fred.

"Yes," says Fred, "that's much better, much better!" And Mr. Segur was satisfied and contented with the job, himself and the world, for he took a comfortable seat and noisily fell asleep.

"Hey, Fred!" shouted Remus, so the fish in the lake could hear. Mr. Segur shifted to one side, stretched himself and replied "Whatie?"

"You are cheating on Percy. Wide awake, or sleep later in the morning."

Mr. Segur explained that by reason of his not being able to hear all the conversation, it was a very easy matter to fall asleep, and that it was positively not to cheat Percy, but the result of his condition.

He then placed his hands behind his head and fell asleep again. Remus found a feather, so, with a smile and a knowing wink, proceeded to touch up Fred's nose. Immediately, upon the feather coming in contact with the end of the said proboscis, the face behind the nose began making queer expressions, and to twist and twitch. Doc stopped reading and looked over the top of his specks. There was also a merry twinkle in the right eye of Doc, while the other was busy winking at Percy. Doc quietly picked up a straw, so that when 
Mr. Segur backed away from the feather of Remus he backed into the straw of Doc. Fred raised his nose, and then lowered his chin, and, in fact, for a while did everything but awaken. He began to slap unconsciously at the fly. He struck himself in the face, awoke, to find a number of smiling men, who suggested that it was time to go to bed. Shortly peace, but not quiet, prevailed in and about the camp.

Just before retiring I noticed a number of the boys whispering together. They told me that they were going to get up before Fred and get an early start on him. At first I thought perhaps that was a trick of Remus' to get me up early. Maybe it was; yet, feeling the sublime joy of being up before Fred, I joined the conspirators in the idea. The first one awake in the morning was to awaken each one of the others, and in that way we would give Fred a fair chance to sleep in bed instead of a chair.

I then tucked myself in my sleeping bag, heard a mosquito buzz once only and fell asleep. 


\section{CHAPTER XIV.}

Clint was standing outside the door of the sleeping tent, dressing. Doc was just going to get up and his movement awakened Fred.

"Oh, my goodness! It's time to get up, Doc," shouted a certain member of the Syndicate- "time to get up, Percy."

Percy had a little quiet laugh to himself, while Doc, Clint and Mr. Fred Segur maintained an altercation concerning the first one up. Remus had been up previous to this, and when he heard the sonorous voice of a certain member of the Syndicate urging everybody to get up, had jumped into bed and pulled the covers over him. Fred vowed that he was awake first, and that he saw Remus lying in bed asleep; and Remus, with another knowing wink, vowed he must have gone to sleep with his glasses on. Fred didn't notice whether Remus had glasses on or not, but vowed that he was the early bird. Remus also wanted to know how it was that Fred could sleep with his head up against a wooden partition and thus see around the corner of the wall so as to see Remus sleeping in his bed. The buzz, buzz of the altercations put me back to sleep. I had, in a short dream, been fishing in a beautiful lake, had had a wonderful strike and was about to land a musque, when-bluie, bluie, went the revolver of Remus within a few feet of my head. The concussion was so strong that it simply raised me out of bed; then, turning around, I saw the smiling face of a certain ruffian, who wore a large red handkerchief about his neck and a large Scotch plaid vest.

I jumped into my clothes, hurried down to the lake to wash; slipped off the dock, and would have gotten my 
feet good and wet had it not been for my preparedness in putting on a pair of rubber boots.

Upon returning to the grub house I found the table had been set by Fred, all preparations for breakfast begun and in good working order. I arrived in time to ccok a few pike fish, wilch had just been caught, and some eggs. I also served an adequate portion of oatmeal and coffee. In a little while we were the proud possessors of a good breakfast. Remus had packed the shore box; the boats had been loaded by Dan. All I had to do was to grab my fishing coat, pole and box, take my seat at the wheel and away we were headed for Otter Tail Point. Fred, having taken his customary position in the bow of the launch, was proceeding to give directions as to how to get there the quickest way.

We had an early start and a beautiful day. There wasn't a cloud in the shy. A gentle breeze was blowing, enough to cause the waves in the big lake to roll and to put on their white caps. We had to ride the trough of the wave for about three hours and now and then head into the waves.

"Whoopee! that was a he one" (Fred's definition for any big fish or wave), said Fred, "'twas the seventh son of the seventh son-watch, every seventh wavewhoopee, there's another." And then Mr. Segur drew his oilskin coat close around him, took a drink out of the lake and signaled me to drive the boat over nearer Squaw Point.

The other boats were making a direct line for Otter Tail Point. Fred, notwithstanding he had spent thirteen or foriteen summers in navigating the lake, had mistaken a portion of Squaw Point for Otter Tail. He had me drive about three miles out of the way, much to 
his surprise, when he found that he had reached the extreme end of Squaw Point.

Of course the members of the Syndicate, and most of their wives, for whom this sketch is written, know where these points are located; yet, fearing that some of them might have forgotten, and that, possibly, some other friends might be interested, after our boats passed under the railroad bridge, a considerable distance to our left stands a weedy channel to Steamboat Bay; about three miles straight ahead, and about five miles to our left, Squaw Point protrudes into the big lake. This point is surrounded by a lot of shallow water, weeds and a watery growth. To our extreme right Morris Point, and on beyond that Walker; while straight ahead and about a mile to the left of the railroad bridge appears The Narrows, which consist of a watery growth and various bogs, blocking the entrance to the big lake, on Leech Lake proper. On Squaw Point there are a number of Inclian houses, or huts; to the right from Squaw Point lies Pine Point, and then, further on, another bay and Stony Point. Otter Tail Point is directly across the big lake from Pine Point, and an hour's ride from The Narrows.

"Well," says Mr. Segur, as we pass the extreme end of Squaw Point, "the ice and snow of last winter have moved the bog and Goose Island."

This Goose Island stands in the big lake about three miles from The Narrows.

We looked over toward Pine Point and there saw the boats of Doc and Remus heading directly for Otter Tail Point.

"Oh, my goodness!" said Fred. "I thought we were getting there too soon; that was just Squaw Point. There's Goose Island, and on beyond is Otter Tail Point. 
Well, well, Doc's right. I don't see how I could have made that mistake." And then Fred tock another drink out of the lake and signaled over towards Doc and Remus.

We motored on to Otter Tail. It was a wonderfully nice ride. The lake was a little rough, but we were prepared for that. It was very interesting. There stood Otter Tail Point in the distance.

"You know how that came to be named Otter Tail Point, don't you? Well, it is the shape of an otter's tail," and then Mr. Segur traced the shaping lines of an otter's tail for me on the shore line.

This is the best fishing water on the lake. We went up to the extreme point and drifted down with the wind. We had the time of our lives catching fish, and good fish. Fred caught some nice pike. Oh, what a joy it was to see him handle a good healthy strike. He fished and fished and so did I. It was great sport. We caught all we needed very quickly. About two o'clock we decided to make camp for dinner. The other boats came in. They also had a nice string of pike, Doc and Clint having the better string. They caught them trolling at the extreme end of the point.

While fishing along this point the wind had raised, a big black cloud had come up. It was starting to rain. We landed in a protected inlet of the point, and upon slight exploration found the network of an Indian house.

This was of a consiclerable interest to me. It was in a small cleared place in the woods, a little ways back from the lake. The Indians had taken small trees, which happened to be growing in the right place, pulled them over toward the middle and then with pieces of bark had tied them together. They had taken a number of 
smaller branches and trees and made a network of limbs over the top and sides. All of this was put together without the use of a nail. On top of this network we spread a large tarpaulin and over in one corner of the house made a fire.

Every one of the Syndicate prepared a big pike fish, by taking two steaks out of the back, which were free from bones. In a short time a nice dinner was prepared. We there had all the comforts of home. For those who liked cream in their coffee, we had what Fred called "contented cow." We also had fresh milk, butter and cheese. We all ate heartily.

Fred hurried through his dinner and then took a stand as a lookout at the lake, figuring out the best place to fish. As we were lying on the ground, smoking, Mr. Segur had another idea.

"Percy, let's take Doc's boat, and you and I will go over around by Onigum, and thence to Walker, and there we'll do the buying."

"Oh, sit down, Fred, and be patient," shouted Doc. "That's too far out of the way for you fellows to go by yourselves." Fred didn't sit down, but proceeded to argue his point, stating that that was the nearest way to Walker.

Everybody suggested that it was the closest way, but the waves were rolling high and Percy didn't want to risk not finding the inlet, and didn't relish getting out in the cold water and dragging the boat over a sandbar. "Well," said Fred, "I made one suggestion, the first morning, and, by dig, I'll not make another one."

"Now, Fred," says Doc, in a pacifying tone, "you know we are all for you, and your suggestions, but it's unreasonable to go that way now." 
"By dig!" says Fred, as he grew restless. "I want to fish-I don't want to sit on the bank and smoke a pipe; I want to fish. I can sit around at home and smoke a pipe, if I want to, by dig! I want to fish here. Well, come on any of you fellows who want to fish, and we'll fish, if we can't go over to Walker through Onigum," finally urged our fisherman.

The Syndicate was called to order by as many different chairmen as there were members. A vote was taken upon the proposition of Fred. It lost with one dissenting ballot, and we compromised the situation by going fishing.

During dinner it stopped raining. Everything was cold and damp. The wind had grown higher. We fished until about five o'clock. I thought it was time to go home, so started the suggestion.

Oh, my! How the waves did roll!

"Mr. Segui," said I with a smile, as I looked at the high rolling sea, "sons of seventh sons." With this there came a tremendous wave and swish.

"Hey, there! Throw your boat into them. You'll wet us good."

I cut down the speed of the engine, and went into the waves for about an hour. I had put on my rubber boots and big rubber coat and a rubber hat. Fred and I took turns at pumping out the boat. Fred looked so disgusted with his job of pumping, I feel he thought possibly it would be well to have a hole in the bottom of the boat, so it could run out as fast as it ran in. I grew slightly sea-sick. I was cold; very, very cold, damp, and the seat of my trousers was wet, as the huge waves washed over us.

We reached Walker in safety, and while there inquired for the mail. 
"What did you get?" said I to Fred.

"A letter from my honey," was the reply, as he opened an envelope, and with a smile that reached from ear to ear.

"Oh, my! Green ink! Where in the world did she get the green ink?" said Fred, as I seemed to wonder if it were possible to have a love letter written in green ink.

I also had a letter from my loved one. I was eager to read it, so Mr. Segur and I took a little time off, but the green ink stalled him, and he suggested that we pull out for camp.

We climbed back into our boat. Fred took his usual seat, and usual drink out of the lake. After a couple of hours of pounding the waves, we reached camp.

Doc had gone the shorter way, avoiding Walker, heading from the Onigum Canal to the railway bridge. He reached camp an hour or so before us. He was going to get supper for us.

"Fred, give me the keys to the grub-house," was the cry of Doc which greeted us from the bank as we prepared to land. "Here we have been for the past hour, all locked out. It's growing late," Doc added.

Fred found the keys and Doc hurried away. Clint was at the wood-pile chopping wood. Fred and I looked a little downcast, and Doc suggested that I get busy and peel the potatoes.

I went into the grub house for the potatoes, and found a good fire. The pots were on the stove, and everything in readiness for a good supper.

"Gee, but I am thankful for this!" said I, as I saw that Doc, Remus, Dan and Clint had prepared supper, Doc and the rest of them having climbed in a window and brought the various other eatables in after them. 
We had another splendid supper. All of us sat about the fire enjoying a smoke.

"Well," says Fred, "I guess I'll have to wash the dishes," as he stretched himself and got up; and tramp, tramp, tramp, around he went gathering up the dishes as a man of much business, while everybody else shouted to him to leave them until morning.

"No sirree," shouted Fred. "I wouldn't sleep good if I were to do that." So Percy rolled up his sleeves, and he and Remus helped our worthy and industrious friend.

That over, Fred found a comfortable seat and fell asleep. I prepared a pot of oatmeal for breakfast, and everything was ready. Fred thought of something in his sleep and awoke.

"Percy, put on the oatmeal!" shouted Fred.

Percy dicn't pay any particular attention. Fred made another tramp about the grub house for the purpose of putting on the oatmeal. Much to his surprise, he found it boiling and nearly done.

"Hey, Fred," shouted Doc, "keep out of the vatmeal; that's Percy's job, and we don't need any more cooks at present."

"Well," says Fred, much distressed over it being assumed that he didn't know how to cook oatmeal, "I was only stirring it."

"Well, stirring it; that's just what you don't want to do; let it cook. Oh, Fred, have a seat!" After considerable coaxing, Fred and Doc took a seat. Remus came to the rescue and suggested that we had all better go to bed, as we would be sleeping past the hour in the morning. The suggestion being extremely timely, it was well taken, and in a little while everything was peaceful about the camp. 
I hurried to bed, as I knew the Syndicate would be up early. It was rumored that our friends, the two Pettibones, would arrive in Walker on the morning train, so I expected to be stirred about three or four-thirty a. m. Well, I didn't mind that, as Mr. Pettibone was a most admirable fellow. We had missed him on many occasions-his stories, his wit and humor and, most of all, his delightful companionship.

\section{CHAPTER XV}

Thursday morning of August 17, 1916, found everything and everybody still in and about the camp. No one stirred, excepting to let down the porch canvas, so that a deluge of rain could not pour in on the sleepers. Remus and Dan had planned secretly to go for the Pettibones at four or five o'clock this morning, yet there was a "northeaster" blowing, as the natives would put it, and those who wanted to sleep had a fair opportunity.

I was aroused shortly before six o'clock by the rain coming in on me. It had drenched the bed, but as my sleeping bag was made of heavy ducking, I was all dry. I hung my clothing up to dry by the fire in the grub house and then went back to bed for awhile. I slept until seven o'clock, at which time Mr. Segur couldn't stand it any longer.

"Oh, my goodness! What's the use of a fellow lying abed until the middle of the day?" shouted Mr. Segur.

I shall always have my doubts about seven o'clock being the middle of the day, but Fred, Clint and Remus went for a plunge into the lake after considerable ban- 
tering. About eight o'clock, finding that my clothes were not as yet dry, I decided to enjoy a morning swim.

There was a "northeaster" blowing, I was told from right off Lake Superior. It seemed to me that it was blowing off the ice shores or Greenland or some other similar place. However, not having anyone to banter, and being alone, I slipped out of my warm bed and night shirt and down to the lake I went. Oh, talk about the shivers! Whew! and double whoopee! it was cold to dash from a warm bed to the cold waters of the lake. I made a dash and the cold rain most did take my breath. I slipped when I nearly reached the lake, and fell, rolled over in the wet grass and was thoroughly prepared for a dip in the lake. Much to my surprise I found the lake very comfortable, comparatively speaking, and had a delightful swim.

On my way to the grub house I was discovered by the Syndicate, so I was directed, as I was so duly and truly prepared for the trip, to go to the spring for some butter. After the trip to the spring for butter, it was discovered that the milk was needed, so back I went. After this a few other little out-of-door errands were run, and then back to the lake I plunged to get warm. I was thoroughly warmed in the cold water of the lake, and then made a dash for the grub house, and in a little while found myself dressed, my clothing having dried, and the possessor of a good breakfast.

"Well," said Clint during breakfast, "I can see Charley walking to the dock for the eleventh time, and now, since it his stopped raining some, hear him saying: 'Well, they've just started for us.' If he could appreciate how calmly we are awaiting our time for him I venture he would have something expressive to say to us." 
"Well, we'll start for them in due time," said Doc, and then followed a discussion of the working girl question. Doc started it, and between Doc, Fred and Clint the question was thoroughly threshed and warmed up to such an extent that I thought that each member, upon several occasions, was liable to be threshed by each other. In the controversy Fred got to working on the stove, which had long grown cold for lack of wood.

"Oh," said I to myself, "what's the matter with the woodchopper?"

The woodchopper had something to say concerning the various department stores; their independence and impudence; that he wouldn't buy a "thimble of salt from one of them." After the argument had grown both cold, hot and warm and very hot, the debaters rounded off to Doc and Clint, and as they pretty nearly agreed upon the subject, when they were somewhat disturbed and interrupted by Fred pounding on the cook stove.

"Well, I'd like to quit this job, but I hear my old New England conscience saying: 'A job that's worth doing is worth doing well,' and, by dig, I just can't stop this job now," vowed Fred, as he looked up from his work and discovered a new-comer in our midst.

"Well, Charley!" shouted Fred, as he dropped his hammer and walked over to Mr. Charles I. Pettibone (hereinafter for good-fellowship known as Charley) and proceeded to embrace him as an actor would on the stage.

Charley was welcomed in due form by all of the Syndicate. Remus and Dan, ever true to the cause, and never forgetting anybody, had gone for the Pettibones. Mr. Ira Pettibone was also present. Of course, we were all glad to see him; and he hereinafter will be known as Ira. 
"Well," said Charley, as he gave a healthy and satisfied smile, evidently glad to be with us, "speaking of that old New England conscience, you know that I have known the people of that locality to some extent, and their conscience-well, to say the least, it is very flexible indeed. Of course, Fred's isn't, but the old New England conscience," he added with a chuckle.

"Tell us about the flexibility of the New England conscience, Mr. Pettibone, please," urged Percy.

"It's this way: A native of New England could do anything he wanted to, providing he did not make any outward signs of enjoying it. There would be things, of course, other people should not do, but he-well, he could do anything as long as he didn't enjoy it."

Charley took a comfortable seat and visited with the Syndicate. Somebody got to talking about the boys of today and the boys of yesterday.

"That reminds me," suggested Charley with a smile. "There was a schoolmistress instructing her class. The problem was to give a word and define it. 'Teacher,' says a little boy, 'I've a word.' 'All right,' says she, 'what is it?' 'Fur,' says he. 'Spell it,' says she. 'F-u-r,' said he. 'And now define it,' said she. He grinned and said: 'It means a long distance.'"

After receiving the news from Kansas City by an eye witness, principally to the effect that it was hot as, a long way below the face of the earth, everybody busied themselves at some kind of work for the good of the cause, and Fred, having finished his job, came down to the lake.

"Hey, Doc," said Fred, first realizing that his New England conscience had deprived him of superintending another job, and pointing to Doc, who was, with the assistance of Percy, building a dock, "drive a nail 
here, that will never hold unless you do." Another altercation between Doc and Fred followed. In this case it would have been better for the dock, and especially for Fred, had several other nails been driven where Fred suggested.

The weather had cleared up and the sun had come out to aid us in welcoming the two Pettibones. I was wading around in the lake, carrying big stones over to the dock for Doc, and finally coaxed Ira in swimming, also Charley. The whole Syndicate in a few moments was plunging about in the cold water, excepting Fred, who vowed that he had gone in when the "men went swimming."

We took the launch out into the bay. Remus went along. He seated himself in a high and dry place, and as we swam about and dived he proceeded to play the role of Dan Cupid, and was throwing his darts at the various swimmers who attempted to hold onto the boat.

After the swim we all went to help the Pettibones arrange their beds. Charley found the beds of Doc, Fred and Clint on the floor, and some hay lying about.

"I suppose we have some jackasses with us," said Charley to me confidentially, as he viewed the hay and beds on the floor, when there were plenty of cots.

"Ha, ha," chuckled Charley to himself, "that reminds me of a little instance of Bill Nye. Bill used to have a friend by the name of Riley. They used to buddy around together, and one time when traveling together both Riley and Bill got pretty drunk. Riley says: 'Bill, you buy the tickets, as you are a trifle steadier than I.' 'All right,' says Bill. And when they got on the train Riley asked Bill if he had his ticket. Bill says: 'No, Riley, I didn't think to buy it.' 'What am I going to do?' says Riley. 'Well,' says Bill, 'when the 
conductor comes around you just get down on the floor and I will throw a blanket over you.' 'All right,' says Riley. So Bill covered him with a blanket, which was handy in those days, and a couple of telescope valises. The conductor cams around and Bill handed the conductor two tickets. The conductor inquired of the whereabouts of the other passenger, and Bill told him confidentially, and very low, that he was down under the blankets and telescopes. 'Why's he there?' demancied the conductor. 'Don't know', says Bill, 'except he is just a little peculiar,' And so it is, possibly, with Doc, Fred and Clint when it comes to making beds on the floor, when there are plenty of good beds and cots."

After preparing the two Pettibones for the night, we all took a seat under the shade of the trees and visited. Clint told of his boys, illustrating how boys, and men and women, as far as that is concerncd, were all creatures of reason, and that it was far better to reason a fellow into the right way of thinking than knock him into the wrong way.

While sitting in the shade in front of the grub house, I noticed on our shore a beautiful canoe. Ira had brought it with him. It looked so nice and trim; seemed just the thing; yet, as I recall a hunch I had when I was looking at it, it made me feel that it was going to be the cause of something happening to somebody. I didn't know what it was, still it looked so trim and nice that it seemed to say, "Beware!" Well, I dicin't beware and, of course, something happened, which in due time will be revealed, to the pleasure of those who enjoyed the fun.

Ira brought a new style from the city. It was the wearing of an undershirt instead of a woolen shirt. Thus the sun had a full chance at a fellow's shoulders and back. Remus had a bathing shirt that didn't have 
any buttons on it to come undone, so he followed the style. -Dan enjoyed doing what Dad did, so he, too, followed the custom of the city. Of course, Percy enjoyed the same pleasure. It is mighty nice to feel the warm sunshine on your back, yet when it comes to feeling it all night, well, some folk can't say so much for it. There were the Atwoods, and Ira, fresh from a shirt, coat and vest, with tender white skin; and what the sun didn't do to them I cannot say. Remus's arms wouldn't brown; they would freckle all right, and good and plenty, but the freckles were too far apart. Dan, of course, was mightily like a rose, and so was his dear father; and Ira was mightily like the two Atwoods. Percy had been on the golf course too often for such as the sun to affect, so he just browned.

After a while we dined. The Pettibones dined. Charley took a portion of the job as chief chef. Everything the market afforded we had, and plenty of it.

A wonderful meal was over. The boys were sitting around in the shade. Ira and Percy went for a fish in the canoe. Ira caught a good-sized pike. For a time there was some question as to which would land-the pike, or the pike land the Pettibone. The Pettibone won in the battle for life and in time we returned to camp. After loafing around there a while, Charley decided that he would take a fish, if he could get anyone to go with him, so Percy, still having a fondness for the trim little canoe, proposed that he would paddle the canoe, as he thought that it would be great sport to see Charley catch a fish from the canoe. So away we paddled.

Oh, how harmoniously did the paddle strike the water and the canoe glide over its surface. We paddled up the shore of Kabekona Bay, and crept up on a bunch 
of wild mallards. We could have shot a number had we had a gun, the disposition and the law.

Charley didn't have much luck fishing and he exposed a portion of his life.

"My! Spealing of good times, ha! ha! What's a good time one time in life isn't a good time in another. When I was a young fellow, and that's now a good many years ago, I was into a good many fool thingsand out of them, too. I remember one of them I got out of about as quick as I got in, and for a while it looked serious. It might have been, yet I was a young fellow, and so was a friend of mine. We were spending a vacation together, stopping at a summer placeGeneva, Wisconsin. There they had a beautiful lake. A passenger boat made the landing ever so often. About the time for the passenger boat to come in, my friend and I were seen on the dock. We got into a hot argument, and just as the boat landed with the summer tourists my friend pulled out a big revolver and shot over the top of my head. At that time I was standing on the edge of the dock. I fell over backwards into the water, sank and swam under the dock. The hue and cry was put in and my friend was put in handcuffs, and then they went to drag the lake for me. They found me sitting back under the dock laughing. I was pulled out. The charge of murder against my friend was withdrawn, and the two of us were given forty-five minutes to leave the community. They made it so hot for us that we took the challenge. It was well we did, for one of the tourists wanted to have us lynched, and he threatened to kill us both for pulling off such a stunt before his wife, whom he contended was in 'too delicate a condition for any such caper." "

"Well," said Percy, "you did stir up a mess, didn't you?" 
"We were just fool boys, but the folk about Geneva made it plain that it wasn't to happen again."

And then we paddled on, enjoying the canoe, the fresh air and the companionship.

"Did you ever do much canoeing," I inquired. "Yes, some," Charley replied.

"That reminds me," said Charley with a chuckle. "On another occasion a friend of mine and I had a canoe. We had put a sail on it, and had started out on quite an adventurous trip. The waves were rolling very high and in the course of a few hours the waves and wind upset us and left us a tossing and a bobbing about a mile from shore. These waves and wind didn't seem to bother us so much for a while, but the wind was blowing off shore and it looked like a pretty long swim. from where we were. A big boat came steaming along. We yelled and made all the noise we could, but the roll and lash of the waves stilled our voices. We could not attract any attention of those on the large boat. It came so close that we could hear the women's voices on the boat, yet they could not, or would not, pay any attention to us, so there we lay a little over a mile from short a tossing in the waves, holding onto the canoe. My friend wasn't as strong as I, and under no circumstances did he feel equal to swimming to shore. After a great deal of consideration, and a lot of effort to hold onto the canoe and take cff my clothes, I turned loose of the canoe and started to swim for shore. I swam and swam against the waves, until I was nearly exhausted. As I approached shore I was so tired and exhausted that I did not dare to let down in the water. I was afraid I would not be able to straighten out and kick again. I swam this way until I reached shore and until my hands and knees struck the 
bottom. I was never so exhausted in my life. When I reached shore I was directly in front of a summer camp. I didn't exactly dare to come out of the water; and finally, despairing upon calling anyone to my rescue, took a run for a tent. There I wrapped myself in a blanket and went in search of aid for my friend. I found some folks on the shore who had been watching us, and thought that we were enjoying a swim. They objected to loaning me their boat, and told me frankly that they wouldn't stand for such a joke. After much pleading, I managed to get a boat and went out and rescued my friend. We were then invited to have a little drink of some invigorating liquor, and in a little while we felt very well pleased with the general outcome of our shipwreck. The next morning when my friend awoke he found himself black and blue all over from the canoe being knocked against him by the waves."

"I can imagine," said I, "that you fellows were right game young men to be out in such a fragile craft. Would you do it again, or take this canoe for a sail in the big lake?"

"No," said Charley, with a smile. "I've had quite enough thrills of that kind."

We paddled into camp. We hadn't had much luck fishing, yet I was very much interested in the stories of my friend when he was "a mere boy," as he put it.

Upon reaching camp we found that Clint, Doc, Remus and Dan had gone to town. They had brought the mail. Fred had another letter from his "honey" in green ink. I also had a letter from my sweetheart, posted at Westhampton, New York.

We had enjoyed such a bountiful dinner that no one was very hungry. We had a help-yourself affair of a 
supper, and everybody took a liberal portion of bread, milk, cheese and breakfast food.

Fred grew nervous over the possibility of somebody leaving the dishes unwashed, so he pitched in, and with ample assistance the job was done. Remus prepared the grub box for tomorrow's shore dinner. In a little while the Syndicate to a man visited the inner chambers of dreamland.

\section{CHAPTER XVI}

FRIDAY, AUGUST 18, 1916, came at a very early hour; so very early indeed, that I did not have time to refer to my timepiece. Doc, Fred, Remus and, in fact, the younger and older members of the Syndicate, took an early plunge into the lake. It was so early that we had finished our swim, breakfast and the dishes, packed our boats and were off on our journey by seven o'clock.

Some member of the Syndicate, I know not who, had decided that we were to go to Kabekona Lake, a beautiful lake at the end of a very long, crooked river, partially filled with bog and all sorts of submarine forests. Kabekona Lake is at the extreme end of a crooked river, which flows into the extreme end of Kabekona Bay about six miles north and west of Lake Benedict.

There was a fresh breeze blowing. The waves were rolling the direction we were going.

In a little while we came to the crooked river. Its mouth was well filled with bog and submarine pines. These pines and their draperies constantly wound themselves about our propeller and made it necessary for one of the crew to hang over the boat and unwind 
them. This had to be done every few minutes. The way to this lake was indeed a wilderness. Civilization had not yet appeared here. There were miles and miles of marsh, bog and weeds and wild rice, out of which constantly flew the wild birds, who, like the Syndicate, were smart enough to summer in that clime, and who, like the Syndicate, appeared to be very happy in their sport. Some distance firom the river and marshes stood high banks and hills. These high banks and hills were thickly wooded. There stood the stately pines. They had the appearance, with their small bunches of foliage on the topmost boughs, to be sky dusters of some giant housekeeper, and the sky seemed to be in such clear shane as to foretell their use. Everything was fresh and clear, like the water on which we rode. We could see the bottom, see whole trees growing the same as on land, and now and then a fish swimming about in the various branches.

As we approached the entrance to Kabekona Lake the curvent g"ew swift. We had some difficulty in following the channel, owing to the crookelness of the river and the length of our boats, yet, after a good many pushes from one side to the other, and oaring, we reached the lake.

We motored across the lake to a fine sand beach. This beach was so inviting that in a little while the Syndicate, to a man, was in swimming. Here the water was cold, yet not so cold as Lake Benedict, and we played about in the water with the same comfort of the wild ducks.

Doc and Clint made a fire on the shore and there we had a fine dinner.

After dinner we cut a number of pine branches and made curselves a very comfortable resting place, and 
were there enjoying peace and comfort until Fred got tired of looking into the lake.

"Well, if nobody wants to fish, I do," said he, looking very serious. Of course, everybody wanted to fish, and in a little while the boats were packed and we headed for the other shore, trolling at a slow rate. The waves grew so high that we found it uncomfortable to fish, and all started back through the crooked river. We reached the inlet. There the cold, clear water was running a mill race.

Fred stood upon a small bridge, which had been condemned, and cast for pickerel. He had not made many casts when a nice sized pickerel, upon seeing his spoon, made a dash for the hook. The water was so clear that you could see the whole performance. The pickerel was darting toward the hook at a lightning pace. Just as the pickerel got to the place where the hook would have been, had it remained stationary, Fred reeled it in suddenly and jerked it out of the water. The pickerel, being intent upon its quest, jumped clear out of the water and caught the bait as he went down, and then a big smile came over the face of Fred.

"Oh, my goodness!" he shouted. "Wasn't that a dandy strike?" It was the most beautiful I had ever seen.

However, we had caught enough fish to eat. Soon the majority of the Syndicate grew tired of casting. One of them proposed a swim, and in a little while the whole crowd, including Fred, were shooting the chutes by jumping in at the head of the river and swimming down the swift current of the river. The current was so swift at this place that the swimmers had to walk back, or swim back in the eddies on the sides.

After enjoying this pastime for about an hour, we dressed and headed our motors for camp. 
The crooked river, which was our homeward path, at some places widened so as to form itself into a number of reasonably good-sized lakes. In these lakes we fished, casting from time to time. We caught a number of pickerel, possibly one and a half feet in length. We threw them all back into the water. We called them "snakes," and while ordinarily they are a reasonably good fish to eat, they were far below our fancy, for nothing but pike steaks came up to our taste.

"Hey, Percy!" shouted Fred, as his serious face turned into a smile.

"Name it. Is it a pike or a pickerel?"

"It pulls like a pike," I responded, as I reeled in my line.

"Yes, that's it. Soe, he is pulling for the bottom," I added, and away darted the fish.

"It's a pike, sure enough," I added, as I pulled a pickerel out of the water and into the boat.

"I told you so," shouted Fred. "You can't tell one from the other intil you draw them out of the water. It is just as much fun to catch a pickerel as a pike."

"Yes," I replied, "but they are not as good to eat." "Yes, that's it," Fred replied.

We had been trolling in the launch. At that moment the motor started up like it would jump out of the boat. Upon looking at the propeller shaft I found that the watery growth had so entangled itself about the wheel that the shaft had been twisted loose. I then started to look for the tools and found that they had been put in the other boat. Dan came to aid me. We found that the pin which holds the shaft in gear with the engine had slipped out. This repair was made and we headed for camp. 
We reached camp at eight o'clock and started dinner. In the course of forty-five minutes' hard work dinner was served in the grub-house.

Everybody ate heartily.

After dinner we all helped Fred with the dishes to the tune of "Will You Washa Da Dish," an Italian opera, composed and sung by Percy for his own pleasure and the discomfort of a certain member who was endeavoring to steal a little sleep from the Syndicate.

"Thank God, that's done!" shouted Fred, as he tramped about noisily in his search for the Ladies' Home Journal, awakening the sleeping member.

"Fred! For goodness sake!" Doc shouted. "You'll knock the house down on us."

"Whatie?" was the amicable reply of Fred, he not hearing about knocking the house down.

"Tell us the story about your cousin Bill Scott," requested Mr. Segur of Percy, as Fred seated himself.

"Yes, do," said another member of the Syndicate, adding that he had heard Mr. Segur explaining a portion of it.

\section{COUSIN BILL.}

"Well," said Percy Field, as he took a good long puff at his corncob pipe, "if you would like to hear about my Cousin Bill, you shall have that pleasure; and, as each member of the Syndicate is more or less interested in the family characteristics of the various members, it might not only be a pleasure for you to hear me tell it, but it may give you a valuable insight into my real character, by virtue of my revealing a trait of another branch of my family."

"Go ahead," declared Remus. 
"Some months ago I was sitting in my office chair, busily engaged in examining an abstract. I had discovered something that looked like trouble, and realizing the possibility of a flaw in the title causing my client expense, was looking rather serious. Someone knocked at my office door.

" "Come on in," shouted my associate, Mr. Pugh. "And then the entrance door opened wide enough to reveal a very heavy-set man about six feet tall.

" 'Come on in,' shouted my associate.

"The entrance door was opened very wide. Indeed, wide enough to present the life size portrait of a merryfaced individual, whom I learned afterwards was Cousin Bill. As the door opened, he removed a large soft hat from a large bald head, and upon placing it near his left shoulder, bowed enough to permit himself to stand erect, and then smiled. When this heavy-set gentleman smiled, I immediately felt its effect; and, to some extent, my profound state seemed to slip away.

" 'Good afternoon,' said he, with another smile, as he placed a pair of nose glasses upon his nose, and proceeded to overlook them with a large pair of true blue eyes.

" 'I'm looking for a young man named Percy Field. Do I behold his handsome presence, or will you be so kind as to direct me to him ?'

"'You will find Mr. Field in his private room,' said Mr. Pugh, as he directed the big corpulent man to my door.

"The big man smiled down upon me, and then bowed. " 'Do I have the pleasure of standing in the presence of Percy Field?' said he, with a profound, but a pleasing, smile. 
"'That you do,' said I, not particularly desiring to get into a conversation.

"'Well, sir, my name is Bill Scott. I'm from —,' as he extended me a large plump right hand.

" "Glad to meet you, Mr. Scott. What can I do for you?'

"Well, sir, you can cease Mistering me. Call me Cousin Bill, just plain Bill; Will, or William, or Cousin Will, or Cousin William, or Cousin Bill-that preferably - that's what you can do for me, my boy.' And then he took a long breath, and with it: 'Why, boy, don't, for the Lord's sake, start out Mistering me. Why, I was the first living man outside of your dear father, to hold you in his arms, so don't Mister me.'

"All right, Cousin Bill," said I. 'I am glad to see you.'

"'And so am I glad to see you, my boy.' And then the dear fellow adjusted his nose glasses very carefully and took a look at everything in my office, including myself.

"Whose's the picture on the wall, with the baby?" he inquired. When he said 'baby' his whole heart seemed to fill the word. 'God bless you, my boy-your wife and child. And you have another pair of bright eyes, too. God bless you again. I'm proud of my cousin. And it's come true, as sure as you are sitting there. When I was a-bouncing you on my knee some, let's see, thirty-two years ago. "What a fine boy, Zella," says I. "He'll 'mount to something." And so he has - a proud father of two lovely girls. How's Cousin Lillian and the two babies?' And when he inquired about the babies he beamed all over, beaming all over their picture, and then beamed at me. 
“'Percy, my boy', said he, with a wink, 'you're just like your dear father-out-married yourself, my boy, out-married yourself-and that you've done. Yet when I look into your eyes I feel that you are entitled to some consideration, especially knowing that your dear $\mathrm{Pa}$ and $\mathrm{Ma}$ left you an orphan, adrift at ten years of age. Yet when I look into your face, my boy, I can't help but say, "God bless you," for you look so like my friend and companion, Zella Mills. Percy, my boy, God never made a dearer and sweeter girl and woman than Zella Mills. Oh, my, I did love that cousin of mine,' he added with a wink.

"'Yet Joe was such a fine fellow, and so was Zella. " 'Oh, my!' said he, as his eyes grew moist, 'I can see them now as they walked down the aisle of that.little church; the bride so young and beautiful, the groom so strong and handsome.

" $M y$ boy, you look like both of them. But let Cousin Bill tell you, you are not half so handsome as your father, or half so charming as your dear mother. Well, well, I'm glad to see you.' And again he demanded that I shake his chubby hand.

"'Well, my boy, you should be the stingiest man in Kansas City or, as far as that is concerned, you would come well by being the stingiest man in Missouri, for you're kin to me, and I am kin to your Uncle John, and John-Oh. well, he's dead now, yet he died as rich as cream, but not with the same love in his heart for his fellow-man as you or I have. Lord Bless us, my side of the family seems to have gotten all of the love and the other side the gold. Yet what's gold when compared to love?' he added with a smile.

" 'Not much', said I.

“' 'Nothing,' he proclaimed. 'But I was going to tell you a little story on Uncle John. You will remember 
that Uncle John was about six feet eight and weighed at no time in his life, excepting when he was a baby, less than three hundred and sixty pounds. He was as stingy as he was big, and his feet were as big as he was stingy, and he had the biggest feet of any white man that ever lived. Well, that was nearly forty years ago, when $\mathrm{Pa}$ and his boys lived in one section of Missouri and Uncle John and wife, Mariah, and his girls lived in another section of Saline county, Missouri. I remember it well. We were farmers. Never before had brother John and I worked so hard to lay the corn by and get the work done on the farm as we had that summer, when $\mathrm{Pa}$ says, "Boys, it's watermelon time in Missouri," and that was in those dear old golden days when we raised big watermelons here in Missouriat least, Uncle John did, as he was the prize fruit grower of the county. "You'd better saddle up about two a. m. and take a trip over to your Uncle John's; he has got the greatest orchard and raises the biggest watermelons of any man in the state, and then he has a bunch of girls, and as girls of a feather flock together, you all may have a grand time," says $\mathrm{Pa}$. We struck out and rode all day. We reached Uncle John's late that afternoon. There he sat in the shade of a pear tree with a sack in his left hand and a fan in his right. He was sitting on a bench especially constructed to suit his dimensions. Now and then he would stop fanning, put his hand up to his ear and then walk over and pick up a pear and put it in the sack. He wouldn't say, "Boys, have one." Oh, no, far be it from Uncle John. He had something else on his mind. After we drove up it didn't take him long to spring it in a clever sort of a way. As we approached our big uncle on his big bench he says: "Boys, go to the kitchen and Mariah will fix you out all right." So to the kitchen 
we went and had a very good meal. John and I decided that we had better go out in the shade and speak to Uncle John. "Good evening, Uncle John," says I. "Howd'y do," says he. "Well, well, boys," says he, "never before in the history of my watermelon patch has it ever been so full of weeds and parsley, and never before have I ever had two such strong boys on the place at the very time. Watermelons," says Uncle John, "never before have I had such fine ones." And he never had such good ones. When he said "watermelons," he just kind a winked a "will you have some, boys?" but for our keener appreciation withheld the invitation. So immediately John and I, while in our Sunday clothes, were furnished a hoe apiece and away we went to the watermelon patch, with the suggestion of Uncle John that it was always best to work and then eat. And work and then eat we did, but not watermelons, or plums, or pears, or grapes, nothing of the kind. Of course, we had fried chicken and such, but for fruit, we could hoe among the watermelons.

" "There was Uncle John a bossing and a thumping the melons. I can see him now, bending over and thumping 'em, and saying: "My, but that's a good one." Then he'd pull them and have me carry them off out of the patch and put them in a wagon. Well, when night came we were all dog tired and went to bed early. Morning came right away, and so did Uncle John with the hoes, and we hoed and hoed and hoed until his watermelon patch didn't have a weed in it. It was in the best shape I have ever seen any patch. Along that night when we had gone to bed and hadn't as yet had a mouthful of fruit or watermelon, John says: "Bill, I don't believe that old man is going to give us any watermelon. If we get it we've just got to help ourselves.' 'That's right,' says I, 'but how are we going 
to do it? If we get in that watermelon patch he will track us and the next morning he'll give up the worst thrashing we have ever had, and I'd just about as soon have a horse kick me as to have Uncle John slap me with that big hand of his." John smiled and says: "Will, I've got it fixed-I've studied it all out." And you will remember that old-fashioned Missouri homethe stairway is outside, goes up around a sort of a closet, into which the farmer of the olden days used to keep his old boots and shoes. Well John says: "Will, you wear Uncle John's shoes and I'll wear his boots, and we'll just simply help ourselves." "Well," says I, "It's a go."

" "That night we had one of the most beautiful moonlight nights we had ever had in Missouri. We slipped into Uncle John's watermelon patch and helped ourselves to the nice big ones-the ones he had been saving for himself for a hot afternoon, as it took a pretty big one to cheer him. We ate watermelon until it didn't taste good, and plums and pears. It was a wonder it didn't kill us, and it would possibly, had we not been in such good shape from hoeing. After we had pretty well helped ourselves we slipped off to bed, and on our way put back Uncle John's shoes and boots. We went to sleep and had some awful dreams. Morning soon came and we were awakened.

“'Mariah!' we heard Uncle John shout, as the first glimpse of morning came to us, "There's been a lot of niggers down here from Miami a-stealing my watermelons.'

"'How do you know they were niggers,' shouted his wife in reply.

"'Lord bless me, but there don't live a white man with feet as big as these tracks.' 
" "And then we both laughed and dressed, and all during breakfast Uncle John made such a roar about his watermelons that brother and I thought it was time to go. We did, and left Uncle John and his wife, Mariah, and his five daughters, who we hadn't seen long enough to say more than "Howd'y."

" "And do you know that a year to a day Uncle John, his wife, Mariah, and his five daughters called on $\mathrm{Pa}$; and after spending a couple of weeks with $\mathrm{Pa}, \mathrm{Pa}$ got to laughing about our watermelon escapade, and Uncle John, after having told $\mathrm{Pa}$ about how the niggers had stolen them, $\mathrm{Pa}$ laughed some more, and Uncle John jumped up.

" "Consarne ye, Bill Scott, yer keeping something back from me," shouted Uncle John, as he stood up and shook his big fist in Pa's face. Pa jumped up, too, and in the altercation that followed, the house most shook. Uncle John vowed that if he, Pa, didn't let him give us boys a whaling (a year afterwards) he would cross my father's threshold for the last time.

" "Well," Pa says, "John, it served you right. I don't thank you for forcing my boys to steal watermelons, and I don't blame them a bit. But if you are so stingy and cussed as that, there's the door and the threshold. It won't miss you!"

"So Uncle John got right up and loaded his five daughters and wife, Mariah, into a wagon, drove away, and never returned. He died as rich as cream, in money, but powerfully poor in heart.

"'So you see, Percy, my boy, you ought to be the stingiest man in Missouri. You'd come well by it,' added Bill with a smile and wink."

"Tell us about your Cousin Bill's reception of Mary," urged Mr. Segur. 
"Yes," said Clint, "Cousin Bill is quite a character; tell us more about him, and then I'll tell you a story about an old friend of mine."

"Very well," said Percy, slightly out of breath, as he struck another match for his pipe.

"After Cousin Bill had related the story about Uncle John, he asked me what had become of Mary Cook.

"'Mary Cook,' said I, 'let me see. Oh, yes, Mary Cook Wagy.'

"'That's the girl,' said he. 'By goodness, she was a pretty girl; yes, the most beautiful girl that ever visited in Saline county, and we've certainly had a few. Cousin Mary-my, I'd like to see that girl. Percy, is she still as sweet and charming as she was?'

" 'Cousin Bill,' said I, 'I can't vouch for the beauty of a girl thirty years ago, but today I know not another such woman. She has always had a place in my heart. She's coming down to see me, and I expect her most any minute.'

"'Percy, my dear boy, this will indeed be a pleasure,' he added.

"And then Cousin Bill got up and began fixing his tie, adjusting his collar and dusting off his coat. $\mathrm{He}$ sat down and attempted to brush up what was left of his hair.

"'My boy,' said he, beaming' all over, 'when she comes in don't announce me. I have a surprise for that darling girl.'

"In a little while Cousin Mary entered my outer office. 'Come in,' said I, 'Cousin Mary.' And in she walked, and took a seat by my desk. Cousin Bill was sitting in another chair in the farther portion of my office, adjusting his tie and dusting off his coat, beam- 
ing first at me and then at Cousin Mary. I looked over my shoulder at him and found him in a state of near explosion. He was staring at Cousin Mary so much that she grew uneasy, and looked steadily at me, and turned her chair so as not to see her kinsman. Cousin Bill then stood up, placed his nose glasses upon his nose, and positively stared at Mary.

" 'Well,' said he, as he approached with outstretched arms, 'I like you. Yes, rny dear. God bless you, Mary; I love you.' Cousin Mary started to scream and call for help, turned and saw Cousin Bill."

"'Will Scott! I'm delighted.'

"Then Mary and Bill embraced, and Bill gave Mary an old-fashioned kiss with a smack which could be heard in the outer office."

“'Mary,' says Bill, 'you haven't changed one bit in thirty years, excepting to grow more beautiful.'"

" 'And neither have you, Will,' added Mary, as she took Bill's arm from around her waist and blushed; and with it came the roses of by-gone years."

"Thus my office was the stage, and my kinfolk the players, while Bill and Mary were mere children playmates, who wandered in the gloaming. I visited with the boy and girl of yesterday; and scon, yes, too soon, did they have to leave. With them went a shining light, and, while my Cousin Bill may never die as 'rich as cream with gold,' yet, in heart, he will be far richer." "He must be a good character," added Fred.

"Now let us hear your story, Clint," demanded the Syndicate. 


\section{THE TWO SWEETHEARTS.}

"Speaking of personal experiences, there are always characters in real life, who maintain a great deal of interest. There is my ministerial friend, Doctor Porter. He was pastor of the Olive Street Baptist Church in Kansas City for a good many years, and there I became very well acquainted with him. Doctor Porter was a mighty good man, and was quite often, by virtue of his goodness, imposed upon. While I was in San Antonio visiting my son, I called upon the Doctor, and during my visit he told me of one of his experiences."

"I was at home very busy preparing my Sunday work, when suddenly the telephone rang,' said the Doctor, and proceeded, 'I answered, and after the customary salutations, my telephone caller said: "Doctor, I'm in a heap of trouble-I am down at the hotel in room number four seventeen. I don't like to talk of matters of this nature over the telephone, but I need your assistance, and if you will only come and see me I am sure you will do me a lot of good. Please come, for I am certainly in a lot of trouble."

"Of course, Doctor Porter was one of those good souls, and had to go. Down to room four seventeen he went, and there he was ushered into the presence of a very old couple. There, as the Doctor told me, he was introducd by a strange old man to a lady of about sixty-nine. She was sitting in a straight back chair, on the edge of it, had her arms crossed, and was nervously fanning herself with a little old-fashioned fan, while two yellowish white curls moved gently across her troubled brow from the breeze of her fan."

"'Is that Doctor Porter?' asked the old man. 'Yes, sir,' was the response." 
"'Well,' added the old man. 'This lady and I were sweethearts fifty years ago. We were engaged to be married; the war broke out and I joined the army; went away, settled in another section of the country and married. I married a very good woman, and she, afterwards, married a very good man. My wife died many years ago, and her husband died equally as many. Destiny made it possible for us to meet again, and there, at that meeting, we revived the old spark of love-and decided to get married-so we have come to San Antonio to be married.

" 'On our way here, after she had looked out of the car window for a long time, she asked me if I loved her more than any other woman-if I loved her more than my former wife. Of course, Doctor,' said he, 'having still a remembrance of the love I bore for my first wife, I told her that, as my wife was dead, that we had better not draw such comparisons. Then she rared herself up and said, "Well, if you don't love me more than any other woman, we had better not get married-and I'll not marry you."

"So here we are, Doctor. I have made every arrangement, and she still vows that, as I did not answer that question satisfactorily to her, she will not marry me. Now, it has occurred to me, if you would explain the situation to her, that it would be well that we should spend the balance of our lives in the happy union of husband and wife. Please talk to her about the matter." "

"Then the Doctor said he sat down beside her and talked patiently and kindly, explaining the virtue of her to-be husband, in his reply urging that he should not be turned down for such a reason.

"The Doctor told me that he didn't notice any perceivable effect he was having upon the to-be bride, 
but that she simply sat there, all straight and rigid, and fanned."

"'Step around on the other side,' said the old man. 'This is her good ear, and you have been talking on her deaf side." "

"Please come on this side and explain the matter to her.'”

"So dear Doctor Porter got up and walked around to the other side. When he had come over to the good ear, she stood up and switched, and asked sharply what he was coming over there for."

" 'Well,' said the Doctor, as he explained it all over again to her; and then, to his surprise, she stood up and said, 'Well, if he must marry me, he must. So if you are a minister, the quicker you perform the ceremony the better.'"

"Then the Doctor asked the bridegroom if he had a license."

"The bridegroom responded that he was in a strange city, that he had not attended to that, and requested that the Doctor do this for him. So dear old Doctor Porter called up the recorder, and was told that the recorder was entertaining at dinner, but that owing to the fact that Doctor Porter wanted the license, he would have it ready for him, if he would call and get it.

"So the Doctor went on the errand, after being told to pay for the same and keep account of the expense; that the old man would pay for the whole thing later. The Doctor went out and procured the license and returned. Then the two old folk stood up and were married according to law. 
"After the Doctor had wished them a long, happy life, the groom said: 'Doctor, please address this envelope to you and stamp it." "

"The groom took the Doctor off to one side, and thanked him, and told him that he had spent the last cent to come to San Antonio, and that if he would give him this self-addressed envelope, he would send him the money just as soon as he got home-that his wife was rich, but that he hadn't been married long enough to ask a financial favor of her, but that he would upon reaching home. Doctor Porter went home, after having performed the ceremony, yet, he told me frankly that he has waited long and patiently, but the self-addressed envelope had never reached him."

"Well, the old fox," cried Percy.

"Yes," said Charley. "I can just see that little old woman sitting all cocked up in a straight back chair, with her white hair and the little curls of yellow and white decorating her temples-ha, ha-such is life." 


\section{CHAPTER XVII.}

Morning came of the day of the 19th of August, 1916, and with it a cold rain. Everybody seemed to be tired and slept as late as eight o'clock.

We took a swim, had a good breakfact, found a dry place in the grub house, and Doc, Clint, Charley and Percy played cards.

After awhile, the weather cleared up, and Fred got Doc to take him to town, to get a number of "dodads," with which he wanted to fix the motor in the big launch. So off he went, and in due time returned.

Dan put the large motor in splendid shape, and we were prepared for another trip. I wrote a letter to my darling in Westhampton, and Remus and Dan went out in the canoe.

There was not much doing today, so after dinner, those who liked to read, read; and those who liked to sleep, slept.

We played cards after supper and went to bed early. 


\section{CHAPTER XVIII.}

August 20th, 1916, was Sunday-another beauitful morning. Some of the Syndicate talked of going to church, while others got busy, doing this and that, so that they couldn't be persuaded one way or the other.

The Ericksons (natives of Walker), came down for a fish and brought the mail.

Today Fred couldn't fish, yet, his New England conscience would permit him to row the boat for any of those who wanted to fish, and most of the Syndicate, not caring particularly for another fish, sat around in the shade and smoked and talked.

Percy Field peeled a lot of potatoes, rutabagas and cucumbers. And right here let me say a word about the cucumbers. Never have I seen such fine cucumbers, so big and tender; and such a relish did they make. We had a fine dinner, fresh fish and most everything which the market afforded. We all ate heartily and returned to our comfortable positions on the lawn.

"Speaking of water," said Chariey with a smile, as Fred went for a drink.

"There was a Presbyterian who married a Baptist. His wife was mighty fond of fresh mackerel."

“'My dear,' said he, 'why are some Baptists like fresh mackerel?"'

“" 'Don't know,' said she.”

"Sometime later, at a gathering, when the preacher was there and they were talking about Baptists, the question was put again by his wife. Of course, the preacher was very much interested to know why some Baptists were like fresh mackerel. 
" 'Why's a Baptist like fresh mackerel,' the preacher inquired.

"'Don't know' said he, unless it is that they spoil so soon after they come out of the water."

Mr. Stephenson took a long puff at his pipe and suggested that he had his doubts about the majority of Baptists spoiling as soon as they came out of the water. Percy Field stretched himself and chuckled.

We had another help-yourself affair of a supper and everybody sat around the stove.

Doc and Remus got into an argument over the railroad question, which developed into a dispute. The discussion grew very warm and the differences of opinion very wide. Doc's argument tended to support the socialistic idea of the apportionment of the profits of the railroad companies among their employees; while Remus felt that the people who composed the railroad company, who had put their money into the hazardous undertaking, were entitled to all the profits, so long as labor was fairly compensated.

While this discussion advanced the stove was forgotten, and while the argument grew very warm, the stove grew very cold.' The matter was disposed of very satisfactorily to all parties concerned, excepting Doc and Remus, by Doc and Remus being requested to take a little heat out of the argument and put it into the stove.

We then all toasted ourselves and after absorbing the desired amount of heat from the stove, went to bed. 


\section{CHAPTER XIX.}

We awoke this morning, Monday, A ugust 21st, 1916, in the midst of a terrible storm.

We had planned to go to Ottertail Point this morning for the benefit of the Pettibones; yet, the wind and rain was blowing to such an extent that it was impossible to venture out, so we all tucked our blankets around closer and slept late; that is, as late as six o'clock.

At that hour, I sprang out of bed and jumped into my clothes. I felt I had just as well get up and awaken some of the others as to attempt to sleep and have some of the others awaken me. After dressing I went over to the grub house and there found Remus making the fire, and starting breakfast, by setting the table.

Remus and I got a regular breakfast.

After breakfast I found that winter wear was very comfortable, and so did a number of the other members.

After the various changes Charley and I beat Clint and Doc at high five. We did this two or three times. It was a very pleasant game, however, and reasonably close.

Fred busied himself reading, maintaining that he was a reasonably good whist player, but couldn't understand the game of high five.

Ira Pettibone and Dan put on their rain coats and warm clothing and walked to Walker. They did not reach home until after supper. As the hour grew late Doc and Remus grew very much alarmed, fearing that the boys should get lost in the woods. Just as the Syndicatie :were putting out a scouting party the boys returned to camp, and that relieved the tension. The Syndicate being tired with the slowness of the day went to bed. 


\section{CHAPTER XX.}

The morning of Tuesday, August 22nd, 1916, came early, and with it a delightful freshness. Everything in and about the camp had been thoroughly washed, and now as the sun shown brightly, appeared in its finest dress. I arose at my usual hour, not early and not late, six a. $\mathrm{m}$. The canvas curtain had been pulled down the night before, and this kept the sun from shining in on a number of the Syndicate, and did not give the alarm of the approach of day. I dressed very quietly, and then started to go to the grub house to prepare breakfast. On my way to the door I was astonished. There lay in peace, but not quiet, the slumbering body of Mr. Frederick W. Segur. He looked so peaceful there, that I stood over him for a few minutes, and beheld a man with a clear conscience asleep. Buzz, buzz, buzz, was the reply to my meditation. I reached over and was in the act of awakening him, when I thought of his remarks on former occasions: "Oh, my goodness, I can't lie abed after 4:30 a. m." Yet, there he lay, sleeping, and the hands of my watch pointing to six o'clock and fifteen minutes after. I could not stand my keen delight of being up ahead of Fred longer, so I shook him.

"Oh, my goodness," said he, "I've been a-napping." And he had.

Fred got up and stretched himself and yawned. $\mathrm{He}$ dressed very quickly. Upon walking toward the door he found Dan sitting on the side of his bed lazily stretching himself.

"Let's go swimming, Mr. Segur," said Dan drowsily.

"All right. I'm for swimming every morning at this hour," shouted Mr. Segur, as he threw his hat in the corner and pulled open his shirt. 
"Oh, gee!" replied Dan, as he looked out of the door and began to appreciate the freshness of the morning, adding, "let's not go in?"

"All right," said Mr. Segur, as he buttoned up his shirt and started for the grub house.

"By dig, Percy, it just seems as if I can't get anybody to go swimming this morning," added Fred, confidentially suggesting that he was very well pleased with the disposition Dan had made of the matter.

We then hurried over to the grub house, prepared, and had breakfast. I didn't hear anything more about going swimming. The air was cold and frosty.

This morning we had decided to go to Ottertail, but the waters were still rolling high on the bay, and we felt that they would be much higher over by Ottertail Point. It was decided later to go to Onigum and fish in the bay.

Shortly after starting out for Onigum, Ira got lost from the rest of the boats, in the canoe; or the rest of the boats got lost from Ira.

We all then started a search for him. We found him over by Squaw Point serenely paddling for Ottertail. We then took Ira in our boat, hooked his canoe on behind and went to Onigum.

We then found that Doc and Clint had gone on to Ottertail, so we made for the cutoff, or canal at the extreme end of Onigum Bay, and headed our boats for Ottertail Point.

Going this way to Ottertail Point, we have a direct line, after going through the canal. We got through this natural canal all right, after cleaning our propeller a number of times, and pushing over the sandbar.

Just over the edge of the bar, there was a sort of a deep hole and out of it bubbled a big spring. The water bubbled up three or four inches out of the lake 
proper. The waves were very high, but as the wind was blowing toward Ottertail Point, we had no difficulty in reaching the Point. When we did get there, we had considerable trouble to find a place to land. The waves were running a perfect millrace around the Point.

We rounded the Point, and in the quiet water proceeded to look for a place to land, a camping ground for dinner. I was growing hungry and so were a number of the other members.

We found a small inlet where it was just possible to land, and tied up our boats. I didn't like its looks very much, so cut loose the canoe, and got into it very carefully. I got into the extreme rear end. Of course, that end went down quite a distance and for a moment balanced on the edge of a rock. At that very minute I felt it was time for my hunch to come true about the trim little canoe. I had gotten my feet and legs under the bar that holds that end of the canoe together. About that time, a big wave came rolling in from the Point and over I went. Of course, it wasn't very deep there, and wouldn't have made much difference if it had been, yet, over I went, side and head first, into the cold water of the lake with all my clothes on, and the canoe on top of me.

At this moment Fred was in plain view upon the bank. I thought he was a friend of mine, and had he fallen in the lake, possibly I would have sprung to his rescue, and yet, probably, under all the circumstances, I would have done the same as he did.

Well, he stood first on one foot and then the other, and laughed outright at me; and then he called Doc's attention to the affair, and Doc laughed.

In the meantime I had disengaged myself from the canoe, and not seeing anybody else particularly 
desirous of saving me from the cold water, proceeded to rescue myself.

"Oh, my goodness," were the words of Fred, "you should have seen the expression on the face of Percy, as he was falling-I can't describe it to you, but I thought I would die a laughing-ha, ha, there he was, in a predicament, as though something was pretty sure to happen, and he couldn't stop it."

And then the other boats came along and I was in finde shape to help land them, so my ducking wasn't so bad alter all.

After landing the boats, I removed all of my clothing, hung it on a limb of a tree to dry, and went for a swim.

I had a fine time splashing about in the cold water. In the meantime Doc and Charley had prepared a good fish dinner with some fish which had just been caught. I found my big hunting coat and put that on and had a delightful dinner, excepting for the occasional visit of a mosquito.

We had an exceptional visitor for dinner. This visitor was a peculiar looking grayish brown bird, which hopped into our midst. It was the most familiar of all the wild creatures I had ever met. It hopped on my shoulder, and then on Doc's foot; and then it hopped around and visited all of the members of the Syndicate, and finally hopped on a hot stone and flew away.

By the time we were ready to fish again my clothing had dried. I was mighty glad of it, as it was blowing cold.

We fished in the waters around the Point and there caught several fine strings of pike.

At six o'clock we started for camp, across the wild looking waves. I sat at the wheel of the launch and 
drove the engine, and for about four hours drove into the waves. It was slow, wet and cold work.

We had a wonderful supper at about eleven o'clock, and then, one by one, crept away to bed, leaving Fred and Doc. Fred had fallen asleep again. After awakening Fred, I started to close up the grub house, and upon knocking the ashes out of my pipe, I found Dr. Leonard had fallen fast asleep in a chair. He had been reading a story, yet sleep had called him, and he was away from the world and all. So, shortly after "waking the boys" and putting them to bed, my hour for getting up came.

\section{CHAPTER XXI.}

It was six o'clock, August 23rd, 1916, and time to get up. I arose and looked at my watch. It was six o'clock, all right, although it felt like two, yet, there wasn't a member, excepting one, who didn't like to lie abed in the morning, astir. Yes, there was Fred. This morning I again remembered what he had to say about not being able to lie abed in the morning, yet such an expression don't count when a fellow's tired, and the intensity of fishing has worn off a little. For as I finished dressing and looked over the camp, there lay Fred, as peaceful as one could imagine. The angels in heaven, I know, coveted his peace. There he lay asleep; and as far as that is concerned, there lay our dear Doctor, and Clint, and Ira and Charley. They were all sleeping so serenely. Ira had folded himself up like a jackknife, while Charley had failed to remove his hat, or had wilfully kept it upon his head, endeavoring to make it take the place of hair. 
"Oh, how wonderful is sleep. The greatest gift of all to mankind!" I murmured to myself, as I looked first at one and then the other.

We live in a busy world. Some folks say, and I believe it is to some extent, that the early bird catches the worm. There are men who must fish; there was the Syndicate, all desiring an early start; there were the early birds; there were folk with a reputation to maintain as early risers-yet, there before me they were sleeping. My keen appreciation of again being: up and dressed ahead of Fred prompted me; and then, too, I recalled that he had awakened me at an early hour, so possibly, as the angels in heaven coveted his peaceful sleep-and then, I might have been prompted by another agency. I leaned over his bed, gave him a shake.

"Mr. Segur," said I with a smile, "will you have your breakfast in bed, or will you come for it?"

Oh, my goodness, of course he could get up for breakfast, and so he did, and so did the rest of the Syndicate.

Remus and I left the sleepers to hanter over going swimming at the time "when men go in swimming," and prepared a good breakfast.

We had fresh pike fish, ham and eggs, and oatmeal, coffee and cream, for those who like cream in their coffee and oatmeal; and then, Doc cutshined himself on the cakes. We also had a liberal portion of fried potatoes. Outside of that we didn't have very much to eat, excepting, however, I will add in confession that the majority of the members also ate two eggs, and some three.

After breakfast the Syndicate chided Fred considerably about being an early riser and also about per- 
mitting Percy to have awakened him for the second time.

"Well," said Fred, "there is one thing about getting up in the morning, and there's another about going for a dip in the lake at the hour when men go swimming." And Doc, having been bantered by Fred and Clint, just sat still and smiled.

"Where shall we go today," said Doc, after the Syndicate's attention had been called to the fact that Doc, Clint and the rest of them, hadn't gotten up, and that they, and especially Doc, hadn't gone in swimming at the time "when the men went in swimming."

Somebody said Stony Point, so away we went for that place.

Mr. Segur took his usual place in the bow of the launch. I drove the engine, and after Mr. Segur had found a cup to drink out of the lake, and had taken his usual drink, we were off on another fishing trip to Stony Point.

The trip to Stony Point is very similar to that of the trip to Ottertail Point, as it stands directly across the lake from Ottertail Point.

We arrived there a little before noon. There we found the same old Stony Point as we had left the year before; and the same big stones, standing in the same places. It was very hard to land our boats at this place as there were a number of big rocks a few feet under the water. Nevertheless, we found a satisfactory haven, landed our big boat, and then went for a fish in the canoe and the other two boats.

In a little while we had plenty of fish. We were going to have a fresh fish dinner; yet, upon looking in our box found that its packers had left out the grease, so we had a meatless dinner. 
After dinner we all fished until we had plenty fishing, and then drove back to Walker.

In Walker we found a letter for each member of the Syndicate, and another awaiting Mr. Segur, written in green ink.

In due time we reached camp. There was the usual stir. Clint chopping the wood, Doc starting up the fire, Percy fixing the potatoes, Fred going down to the spring-in fact, everybody was busy.

A fine dinner was prepared, and after each member eating a great quantity of fish, potatoes, corn on the cob, rutabagas, onions, bread and butter and cucumbers, he pulled his chair back from the table in a satisfied manner.

"There was an old Irish woman," said Charley with a smile, as he made himself comfortable and took a puff at a store cigar, "who was returning home with a can of beer. On her way home she was horrified to see the priest. 'And, good aveninin.' says the priest. 'Good avening,' says Mrs. Murphy, as she placed the can of beer under her apron. 'Faith, I pray, you have not a tumor'?' said the priest, inquiringly. 'Nay,' said Mrs. Murphy, with a roguish laugh, 'nay, it's no tumor, it's a can, sir.' And then Doc smiled, together with a number of other members.

"That reminds me," said Doc, with a twinkle in his eye, "Mrs. Murphy's husband was riding home in a street car. On the way home the car went around a curve, and threw Mr. Murphy into the lap of a woman. "And where do you come from, you rude thing?' 'And sure and,' says he, 'I was born in Cork, Ireland,' taking advantage of an opportunity to speak. 'But ye look more like a Laplander to me,' said she." 
And then we sat around the fire, and those who liked to smoke, smoked, and those who enjoyed reading, say, the Ladies' Home Journal, read.

"What time shall we start tomorrow?" asked Fred.

"I think," said Remus, with a smile, "that it would be better for some folks to do more getting up, and less talking about it."

"Well," says Fred, "when I was a boy, about fourteen years old, I was ruined for sleep. I had to get up at four thirty every morning, from the age of fourteen to seventeen; and I've been ruined ever since. Can't lie abed at all in the mornings," reasoned Fred. A number of the members of the Syndicate smiled, while Percy suggested that he did at one time in his life have to get up at four o'clock, yet said that he was still able to sleep. Clint added that he was going to tell a story about getting up early in the morning, but there was no telling where these stories would lead. Mr. Segur then looked very serious and nodded, as if to say, that was the way I had to get up in the morning.

"Now," says Clint, "I have heard a certain member say: 'Oh, my goodness! I made one suggestion as to where we should go-nobody paid any attention to me; I'll not make another,' so I am going to suggest that tomorrow be Mr. Segur's day. That we get up at whatever hour he desires; go wherever he desires, and fish, or not fish; in other words, tomorrow shall be Mr. Segur's day, and we shall do his bidding."

"All right," says everybody, excepting Fred, who further suggested that as tomorrow was the last day which Clint could be with us at camp, that this should be his day. To this proposition everybody assented. "I suggest for Clint, as he has never been there, that we go to Steamboat Bay and Steamboat Lake," put in Fred. 
"All right," said everybody.

"What time would you suggest we start, Fred, urged Remus. "We want to have tomorrow just right."

"Let us make a reasonably early start, say as late as four forty-five," said Fred seriously.

"Four forty-five it is," affirmed Remus with a smile, and four forty-five it was; for Remus and Percy attended to that matter.

After the disposition of such a weighty subject as to time and place, we went to bed.

\section{CHAPTER XXII.}

Thursday, August 24th, 1916, began at four fortyfive a. m., at our camp. I know it did, as I was there and helped to attend to those little matters. And at that hour in the sleeping camp, there lay the sleepers. They couldn't lie abed in the morning. Of course, they coulcin't. Mr. Segur had requested it-and this was Mr. Segur's day. Mr. Segur was sleeping late, yet he had requested that we get out at four forty-five a. m., and we did, and he did.

Mr. Remus and I hurried over to the grub house and started a fire and breakfast. There was a big: bowl of oatmeal for each member of the Synicate, fried fish or a slice of ham, or both; two or three eggs; coffee, with cream or without; and cakes-the kind which Doc used to make. Oh, my! Talk of the things mother used to make. We had the kind of cakes Doc used to make.

Remus packed the box, Dan put the gasoline in the boats, while Mr. Segur washed the wishes with the assistance of Clint. 
"All right," says Fred, "push us off for Steamboat Bay."

Steamboat Lake and Steamboat Bay are at the end of another very crooked river, which flows into the extreme end of Sucker Bay. The river is filled most of the way with submarine forests and water lilies. It winds its way into a wilderness. We pass through many acres of wild swamp land; and then, many more of the tall and stately pines.

"The virgin forest," says Fred, as he pointed off to a huge bunch of sky dusters.

After we had gone a little way into the crooked river, we found that it was most closed with bog. There was a place, however, about six inches wide, and a few inches deep, which had the appearance of being used as a passage for the canoes of Indians. Into this Doc wedged his boat. The light launch stopped, and it was all hands pull and push.

"Oh, my goodness! It's a shame. We won't get to fish in Steamboat Bay. Drat that bog. Drat it!" said a certain member of the Syndicate, despairingly.

"Oh, come on boys," shouted another member. "Just a little more. Now, together," and we pushed. The boat went over the bog, and away we went again. Dan's boat was pushed and pulled through; then came the big launch.

"Oh, my goodness!" says a certain member of the Syndicate as he pushed and nearly fell in the river. Yet, after about an hour's work we succeeded in traveling about a mile and then we met another place where the bog had blocked the channel. We had all of the work to do over again.

For professional purposes, possibly, after it was satisfactorily done, Doc was very careful about one 
thing-that is, he left his card sticking on a log along the side of the bog.

We then sailed up the river for three hours and a half, ant enjoyed the beautiful scencry of the Northland wilds. There we saw a lot of wild game, wild ducks, geese and cranes. The air was simply filled with flying birds of various species.

We reached Steamboat Bay and camped on the shore not far from a sawmill. There we tied our big boat, and went frogging for bait.

We met a young man by the name of Oscar, whose parents had ventured into the country in a sawmill enterprise.

We scon caught plenty of frogs and went for a fish. We didn't find fishing very good. The water was too rough; yet Dan came in ior dinner with a pilke twenty-seven inches long and weighing six and cre-half pounds. It looked to me like it ought to have wcighed more, yet that was the weight on the fish scales. It made a dandy meal for the Syndicate. Dan kept the head and said that he would mount it.

Oscar took dinner with us. After dinner he went for a fish with Doc and Clint. We fished until four o'clock and caught enough for our own use, but had no particular luck. None of us caught any big ones like Dan. And this, notwithstanding the fact that $\mathrm{Mr}$. Segur fished hard and consistently all the rest of the afternoon.

Our homeward trip was pleasant until we came to the narrow passage. There we found the card of Doc still untouched-and doubtless it is there yet, advising the world that he was there.

After reaching the mouth of the river we steered out into the big lake, and passed around Minnesota 
Island. It was the long way around, and the waves rolled mighty high. Still Charley said this is the better way, as it would be mighty easy to lose your way among the islands and bog; and you might have to go back and start out again. So we took the long way home, and here the long way around proved to be the shorter way home.

Our boat reached home a long time before any of the rest of the boats.

After we had supper about prepared we heard the motor of Doc and in a little while our alarm was eased about Doc and Clint.

"Doc says," shouted Clint, with a smile, "Sir Henry Hudson discovered Hua'son Bay, so why can't we discover the shorter way home. And we did, but you'd have to walk a part of the way. We got tied up in the bog and had to make a clean start in our discovery."

We all gave a hand and pulled Iroc's boat up for the night. Remus and Dan had gone to look for the shorter route, the same as Clint and Doc suggestedone shorter than Doc expected to discover. We had anticipated Dan and Remus would be the first ones home.

Fred kept himself very busy going from the spring to the grub house and then to the dock, looking for the absent members.

"I think," said Fred, "we had hetter send out a scouting paity in search of Dan and Remus.

"I hear their motor," said Percy, having gotten Fred to keep still for a moment, "and they are about twenty-five minutes away. They sound like they are right over thei'e back of the railroad bridge. They'll have to go back, that will take them about twenty minutes, so I expect them in forty-five minutes." I added 
as I listened to the noise of the engine. It gradually grew fainter and then grew louder and louder. In the course of about forty-five minutes we sighted them in the bay.

"Everything's all right, here come Dan and Remus," cried Fred joyously; and then the busybodies hurried supper.

"Well," said Remus, "we were looking for the short way home-and found it. Yet, there we were, just a little way from the railroad bridge, and stopped by a strip of about twenty-five feet. What? Dinner ready? Good. We are ready for it."

We all sat down to a dinner of flied fresh fishnice big steaks of pike, which were boneless-boiled potatoes, beets, tomatoes, rutabagas, boiled onions and a salad of sliced cucumbers and lettuce. To this we added hot biscuits with good butter; and, for those who liked to drink good fresh sweet milk, milk; and cofiee for those who liked to drink coffee.

After dimner the Syndicate pushed their chair's back. Fred found the Ladies' Home Joumal, and the other members their pipes and tobacco.

"My, what a dandy day! 'Tis the end of a perfect day for sure," said Percy. "Yet there is one sad thing about it; our good friend, Clint, is going to leave tomorrow."

"Well," said Clint, "I dislike to go, as I have had such a good time-every minute of it. Before I go, howerer, I want to appoint a successor to my official capacity. Gentlemen, as I leave camp tomorrow, and the official position of wood chopper, I want to appoint Percy to do my chopping in my stead. He is such a good, husky fellow, and the logs are now getting big and hard to chop." 
At this point there was a young man named Percy, who didn't relish the wood chopping job. To speak the whole truth and nothing but the truth, he was longing for a life-saver, and as is generally the case with a man who had rather do something else, when he is about to be thrust into a laborsome job, somebody came to his rescue.

"No! Oh, no!" shouted Remus.

"Thank you, Remus, my heart goes out to you," urged Percy.

"He's the cook, and in that capacity does so well, that I think he had better keep his old job, and not be promoted to the official undertaking of keeping the woodbox." So I was refused admission into that clan and permitted by force of circumstances and choice to cook.

Mr. Stephenson put a light to his pipe, and the balance of the crowd found a seat.

"It must be very interesting, Mr. Stephenson, to turn the wheels of time back upon Kansas City and those who tended to make it-how the old town must have changed since you were a boy" ventured an inquisitive member.

"Yes," answered Clint, and then he struck another match. "It has changed a heap, indeed."

Then Mr. Stephenson named over a whole host of dignitaries of Kansas City forty years ago.

"And what has become of these good folk," asked Percy.

"Gone! All gone," was the reply.

"Were you in Kansas City during the war?" I asked.

"Indeed I was-a boy, selling papers. During that time I saw a lot of things. That reminds me: during: the battle of Westport, I think, in 1864, when Price 
made his raid on Westport, I was peddling papers on the street. The post commander there in Kansas City had rented an emergency hospital at Fifth and Main Streets-the place occupied by the Hub Clothing Company. I was present when they drove up there with a load of wounded soldiers. Two I noticed were badly wounded. One shot in the leg, and the other in the eye. The attending surgeon examined the man shot in the leg and told him that his wound didn't amount to much and that he would have to wait his time. He then turned to the other man, who was shot in the eye, and examined him. He asked him his name, where he lived, and to what company he belonged. He then dressed his wound and told him that under the circumstances it would not be possible for him to live very long. The ambulance, or wagon, drove up with a lot of others-and away things went.

"About the end of the war two of Quantrell's men crossed the river, at some point south of the mouth of the Kaw, rode over to Wyandotte, and stopped at a barber shop on Minnesota Avenue. They put their revolvers under the chair. About that time a number of soldiers passed by on the outside, and some of them, noticing that there were revolvers under the chair, came in to investigate. They arrested the two men, brought them to Kansas City. They confessed they were bushwhackers; were court-martialed and hanged a few days after that from a scaffold located in the vicinity of the ground now occupied by Convention Hall.

"Another rather amusing incident, that happened during the war: Doctor Ridge and nnother prominent physician, who were considered at that time Southern sympathizers, cheered for Jeff Davis. Some soldiers, passing at the time, arrested them. They were taken 
to the military jail-then located at Tenth and Broadway, where the Coates House now stands. The next day they were tried before the post commander, and on account of their being physicians, and rather than make the punishment too severe, decided that the best way to punish them was to send them to the woodpile to saw wood, while a burly negro soldier stood by and bossed the job. They sawed the wood, all right, but this was the last time they ever cheered in public for Jeff Davis. The Ridge family might now deny this affair, but I was a boy and saw the whole affair, and I presume it was far better to saw wood under a negro boss than to be hanged."

"Possibly," said one of the listeners.

"And then there was another amusing affair-concerning John C. Gage, a lawyer, who is now dead. It was one of his first murder cases. There was a scouting party-at that time Kansas City and its vicinity was under martial law-and all of the persons seeking protection under the United States Government were required to call at the post commander's office and register their names, and those who didn't were told to leave. Among those who registered was an Irishman, who lived on Cherry Street, north of Independence Avenue. His horses strayed off one evening, and early the next morning he found them out on Independence Avenue, in the vicinity about where Billy Sunday had his tabernacle. While he was running his horses, he was met by this posse of soldiers, and they inquired where he got his horses. And he, feeling that it didn't concern them, made no reply. One of the soldiers shot him, and he fell dead. He was immediately buried-without coroner's inquest or anything-and then the citizens stirred up a great howdy-do about it. The soldier, who had done the 
shooting, was brought before the post commander and tried for murder. John Gage defended him and demurred to the evidence-on account of the evidence not proving that a man had been killed--in that proof of the corpus delicti had not been presented; there having been no coroner's inquest, the evidence before the court did not show that a live man had not been buried.

"This was a fiction of the law, but it was enough for the post commander to sustain the demurrer, which was offered by Mr. Gage. The demurrer being sustained, the prisoner was discharged. John Gage said that sometime afterwards, the soldier got some money from his folk, fifty dollars, to be paid to Gage for legal services rendered, but that the soldier told John that he was so hard up that he believed he would just keep it and send it to him later. John Gage vowed that he certainly must have been a rascal, and, possibly, should have been hanged, as he never did pay the fifty dollars for legal services rendered." 


\section{CHAPTER XXIII.}

Friday, the 25th day of August, 1916, brought a cold, gloomy morning. At six o'clock sharp two tall and reasonably plump individuals crawled out of a pair of warm blankets and dressed. After they had dressed they looked over the camp. There were the sleeping beauties, the buzz-buzz boys, sleeping peacefully. There were no more early risers.

It was no longer the duty of the Syndicate to awaken the sun in and about Kabekona and possibly that occasioned the gloomy day.

Remus and Percy were the only two astir about the camp. They started the fire, and cooked breakfast. At seven thirty, breakfast, and a good one, was awaiting the Syndicate.

I don't remember whether anybody bantered anybody about going in swimming that morning or not, but as I recall, all was peaceful and still, excepting for the buzz-buzz of the sleepers until the call for breakfast was sounded.

Then the Syndicate held a very important meeting, and Ira Pettibone was chosen wood chopper, to. fill the vacancy, which would be occasioned by the departure of Clint.

Mr. Pettibone and I had a shooting match. Remus succeeded in putting three bullet holes out of five through the bottom of a "certain tin can," to the entire satisfaction of Ira and the balance of the Syndicate. Mr. Pettibone and I were able to throw a shotgun shell into the air, pick up the gun off the ground and hit the shell before it hit the ground.

Clint packed his fishing clothes, etc., and put on his regular wear, and we had with us-in the words of the 
immortal Doc- "Mr. DeWitte Clinton Stephenson." To be honest with each other, we most felt we had a stranger in our midst, yet good clothes merely covered the good man, and in a little while we saw the same Clint, with his pleasant face, and paid no further attention to the outward wear, excepting to put Ira to work in his new official capacity.

A considerable time was consumed in expressing the regrets of the Syndicate to a man of the departure of our friend Clint.

"Well," says Clint Stephenson, "it is all up to Remus," and Remus vowed that it was all up to somebody else -Clint being in the same department of the railroad as was Remus.

At four o'clock we loaded our boats and started our motor for Walker. The air was fresh and there was such a gale blowing that we had to hug the shore.

On our way to Walker we beheld the most beautiful rainbow I have ever seen. One point touched Morris Point, the other Sucker Bay. As we motored near Morris Point the rainbow disappeared, yet there still lingered considerable of its coloring.

We loafed about Walker, and dined at the "Ain't Got No Ham and Eggs Inn," or the restaurant across the railroad track from the station. We enjoyed the dinner. Some of us ordered milk. The waiter brought us a liquid which had every appearance of being milk, excepting for the taste. We ordered steak and got something which resembled leather.

"Doc," says Fred, after a spell of profound meditation, "does it make any difference to our stomachs, after we have eaten the steak, whether the steak was nice and tender or like this?"

"That's quite a deep question, but I am rather inclined to think that it does. At any rate it makes a 
difference with my stomach," vowed Doc. Then followed the various pros, and likewise as many cons, until the question was thoroughly settled.

After dinner we went to the bowling alley. Clint and I played. Mr. Stephenson bowled his first game, and to make the match even I used my left hand. He beat me the first game, the second I won, and then I won the rubber with my left hand. Of course, Doc and Fred had to get into the game, and for a little while things livened up in Walker; and then Doc and Fred decided we were staying too late in town, and that possibly we were having too wild a night, so we went to the dock; and there we all told our friend Clint good-bye, after giving him the various messages to deliver.

Fred was first to get into the launch. He cranked the motor until he was tired. There was a "do-dad" which would not work, so he turned the job over to me. I found the carburetor was filled with water. I emptied it, and away we steered from Walker.

Charley was in the front seat of the launch. I was at the engine and wheel. Fred, Doc and Ira were assorted according to weight, and all proceeded to direct the boat in a different way home. The pilot was somewhat obstinate and steered straight for home.

Upon arrival each member of the crew vowed that his way was the best way. We reached home at eleven o'clock. We were all cold and sat about the fire for about an hour or so. Finally the fire went out, the new wood chopper hadn't been permanently installed.

The night was cold and clear, the Syndicate, to a man, was fast asleep. 


\section{CHAPTER XXIV.}

We went to sleep with nothing particular on our minds-excepting a certain member of the Syndicate. He was dark and browned now with the summer sun-strong and well. While he was tired, yet his fancy brought him back to a time when he did not sleep alone, in a sleeping bag in the wilds of Minnesota. To the rich base snores which floated about camp he could easily imagine, and in a dreamlike fancy hear the roll of the deep notes of the organ, see the brightly lighted church, some sad and some smiling faces; recall a good man's voice: "Do you take this woman to be your lawfully wedded wife?" For yesterday was his wedding anniversary.

Morning came the same this morning as it did on the 26th day of August, now a good many years ago, to Percy Field, and doubtless the same to a good many more of the Syndicate, yet when he awoke he saw new faces and new surroundings. He was alone, but still with his companions. Some of them were covered with blankets, even though it was six o'clock, and some of them couldn't lie abed in the morning-especially after four o'clock. Fred had been awakened, however, possibly by an inner conscience, and had stepped outside for a moment. Thus, finding everybody asleep, I thought it would be a downright shame to awaken the sleepers, so I laid down and took a nap.

I awoke and found Charley awake, but the rest of the crowd were asleep and seemed to be enjoying their snooze, for there was the usual buzz.

Remus, however, got up, leaving the rest of the crowd to delve in dreamland. 
I was brought from the land of dreams by five distinct shots from his revolver. This thoroughly awakened me. I dressed and found that I was up in plenty of time to get breakfast.

After breakfast Fred and Charley washed dishes and then Mr. Segur sat down, and started to read something. He didn't sit there but a little while until he fell asleep.

"Hey, there, Fred," shouted Remus, as he discovered Fred asleep. "Why don't you do your sleeping before breakfast, or at night? Here you are beginning the day cheating on Percy."

Fred stretched himself, yawned, and started to go back to sleep, evidently not hearing all that had been said.

"Wake up, Fred. Don't you know what bumpers are made for?" continued Remus, adding, "why aren't you up and doing, like the rest of us fellows?"

"Well," says Fred, "this is the first time I have sat down since I have been here. No matter what happens I get jumped on by all of you. By dig, you haven't prepared the grub box yet, and I don't know what I can do."

"Well," said Remus, with a smile and a roll of his eyes, and a wink at Percy. "You might try doing that once, and see how much we care." Fred jumped up and most knocked the house down as he went tramping around the grub house.

The lunch box was packed this morning in a hurry. Everything was in readiness. Mr. Segur had taken his usual place in the bow of the launch and his usual drink out of the lake. I was sitting at the engine. Then followed the regular morning wait. Doc had permitted the milk boy to take his boat across the bay, with instructions to bring it back immediately. The 
milk boy evidently having another notion of what Doc meant, was seen a long way off, riding about as though that was all he had to do. Doc then conducted himself in a very noisy manner, and went through a heap of gyrations which were used to attract the attention of the boy, and amuse the Syndicate. The milk boy probably had something else on his mind and proceeded to take a joy ride, as expressed by Fred.

In the course of a half hour the boy came in, and with him his usual innocent smile. He suggested that the engine was working very well.

Doc started to load his boat in a hurry. He was standing with one foot on the dock, and the other on the boat when he dropped his tackle box into the bottom of his boat.

"I'll say it for you, Doc," interrupted Remus.

"Yes, let me," added Charley.

But Doc never said a word, just went on picking up the hooks.

"Where shall we go," seemed to shout everybody, as Doc pulled the last fish hook out of his thumb without saying anything.

"Durant Bay," shouted somebody. So to Durant Bay we headed our boats.

As we were motoring out into the midst of the big lake, and the cool fresh air began to strike us, and the large waves began to toss our boat, Percy felt so good he couldn't control himself, and sang:

\footnotetext{
"We're on our way to Durant BayThere the pike fish play.

Freddie will catch a fish,

'Twill be everybody's wish.

In Durant Bay,

Where the big pike fish play."
} 
The waves were rolling high, yet they were with us, so they only gave us good speed. Ira was with us, and with Ira went the pretty little canoe. Every time I would look at it I could hear something say, "beware!"

Now the way to Durant Bay is through the Narrows, passing Squaw Point, passing Pine Point, and on down the big lake, about five or six miles beyond Stony Point. This is the longest trip we could possibly take, yet the Syndicate, care free, started it at the late hour of nine o'clock, or after Mr. Segur had his morning nap.

When we got about the middle of the big lake, between Stony Point, Pine Point and Ottertail Point, the pretty little canoe sank. Then followed a skirmish to see which would right itself, the big launch or the pretty little canoe. Finally with considerable exertion -and some instruction on behalf of Mr. Segur-we succeeded in raising the canoe and were on our way very cheerily.

We reached a camping place on Durant Bay about two o'clock. The grub box was landed and a fire built.

Doc and Charley had been missing during the first part of the preparation for dinner.

"Hello, Doc," shouted Remus from the bank, as Doc turned his boat toward the shore.

"Have you got any fish," shouted Remus.

"Narry a one," shouted Doc with $\gtrsim$ smile.

"Now don't that beat us? We have no meat and no fish," Remus said with a tinge of disappointment as Fred went to take a long look into the bay.

In a little while we landed the boat of Doc, and Doc pulled from the side of his boat a wonderfully fine string of pike. 
"Where did you catch 'em?" etc. was drowned by the suggestion, I will take these and prepare them for dinner. Thus we had meat and plenty of it, nice fresh pike steaks.

Oh, how extravagant we were with our meat-it always is the case. We took several large pike fish, cut the skin down the center of the back on each side of the vertabrae, around the gills and on each side of the breast bone, skinned the fish, and then cut the steak out of each side of the back. This piece of meat was generally about a foot long, an inch and a half to two inches wide and three-fourths of an inch thick. It was free from bones. The rest of the fish we buried.

"Doc," said Fred, with considerable sternness to his voice, "it will take a half hour to cook that fishplague take it. I came here to fish."

Yet, of course, dinner had to be cooked and time had to be taken to eat it. Fred contented himself for the time being only, but hurried through the meal, took a drink of water out of the lake, stood on the bank and seemed very despondent. Of course he wasn't fishing, yet there were fish all around him. He had a good stomach full and there still remained on the fish string of Doc and Charley enough pike for the whole crowd to have pike steak for two additional meals.

"Yes," said Percy to himself, "some folk are 'niver' satisfied," as he helped put the grub box into the launch.

Remus and Charley were still sitting on the bank near the place where dinner was served.

"You haven't cooked enough bacon," said Charley, looking at Remus.

"Well," said Remus, "don't look at me as if to -accuse me of being a cook. I was discharged as a 
cook by Fred. He said I took too much time, anyhow. If you want any more, ask Fred to cook it."

"Daresn't," replied Charley, with smile and a wink. Fred had gone for another drink out of the bay.

"Well," said somebody, "there's Fred drinking again. My, but he's a hard drinker."

"Yes, it's a wonder he doesn't turn into a fish, he likes them so, and he most breathes the water."

Doc started a discussion about the subject of almoners. Remus thanked Percy for inquiring as to its particular meaning.

"It is a giver of good; the doer of good. It comes from the idea of giving alms. Yet the thing which is given does not necessarily have to be alms. The doing of a good deed, in a way, would cause a person to be an almoner. So we should all try to be almoners," philosophized Doc.

"By dig," said Fred, slightly vexed, "what in the world has alms got to do with a fishing party, anyway? Ain't you fellows going fishing? By dig, I can smoke a pipe at home; but when I come this far, I want to fish. Now won't somebody go fishing with me?"

"Well," said Remus, "come along with me."

So Remus, Dan and Fred went for a fish; and Charley, Doc and Clint went in another boat, leaving Ira and I to fish from the canoe.

"What time shall we go home," was asked.

"Oh, any time," shouted Doc.

And any time it was. It didn't make much difference. We didn't have any engagement after supper; we didn't have any cooks who would be vexed at our being late; we didn't have any supper awaiting us; we had brought cooks and supper with us. We had no one to disappoint. We were care free, so any time was everybody's time. It was vacation time, that's all. 
The Magawot, the largest passenger boat upon the lake, was anchored some distance up the bay. They had brought a party of city folk to Durant Bay to fish.

They were fiching according to the suggestions of the guides who were rowing the various boats. They were catching some fish.

The other two boats pulled off and left Ira and I. We took the launch and made a tour of Durant Bay, and then heacied our boat for Pelican Island. We then turned toward the extreme southern portion of Bear Island, a considerable distance east and south. We had gotten a number of miles from our camp and quite a cistance out into the big lake when we looked back toward the place where we had camped and saw a huge black cloud coming directly toward us. The cloud seemed to be filled with wind and as it approached it gave a hissing sound. It was as black as ink and blowing directly off shore. In a little while the storm was upon us. As it approached we got into our rubber boots and oilskin clothing and in this way were protected from the lash of the waves. The waves grew angry and seemed to roll with an awful churn.

We headed our bcat toward Durant Bay, and in the course of a half hour drove into shelter of the shore. We drove up to the Magawot and asked the red-faced captain how much he would charge to tow us to Walker. The captain said that the fishing party had chartered the boat; thought that about twelve dollars would be very reasonable and that possibly they would want to charge us fifteen dollars. I suggested something like two dollars, and no dicker was made. The fishing party and the Magawot seemed to be afraid to remain in that portion of the water any longer and pulled out and left us to wrestle with the storm and waves. Down 
the black cloud scooped upon us. Oh, how the lake did boil; how the breakers did roll.

We found shelter near the shore and in a little while the storm passed over and left the sun shining very bright and warm.

With the sunshine there came a rainbow. It was the most beautiful I have ever seen. It began in a portion of the lake near Bear Island, followed a circular path in the horizon and sky until it buried itself upon Ottertail Point. There was a rainbow within a rainbow. All of the colors were distinguishable in both of the gigantic bows.

"Isn't this a wonderful country," suggested Ira. "How grand it is to be here; to be away from civilization; to enjoy the life of the wild."

"Yes," said Percy. "This is God's great out-of-doors; it is the answer to the call of the wild. We speak of civilization and progress, and with it we have the rumble of the great cities. We speak of industry, and with it we have unceasing labor, misery and strife. Of course, happiness follows in its wake, yet do you think that we, in our higher state of civilization, are happier than the primitive Indians were here? Does progress advance our happiness?"

"It is indeed a wonderful place. There is a question as to whether progress is an advancement toward happiness," added Ira. "Oh, my, how easy it would be to drop out of the world. It looks like if anybody would want to hide themselves from the world, it would be very easy to come here and be away from everybody," added Ira. And then we talked of the various universities, the things we did while attending school, he at Wisconsin University and I at Yale. Some of the books we had read, and some of the things we had done in our effort to gain an education. And 
then we turned to our sport. We caught a number of good sized pike.

The waves were rolling very high and it was growing late. We had lost trace of the boat of Dan, Remus and Fred. They were somewhere on the big lake. We were alarmed over the situation. I had not seen them since the storm. We motored from the extreme end of Durant Bay to Stony Point, yet no sign of them could we find. Thinking that they would return to camp after they had got tired of fishing, we tied up our launch and fished again from the canoe. It was great sport riding the rollers. I paddled and Ira trolled.

The sky grew gradually darker and we began to feel alone on the big lake. We divided ourselves into scouting parties. We again motored to the extreme end of Durant Bay, and there we found Dan, Fred and Remus serenely fishing. What cared they for camp and for supper; what cared they for the high rolling waves and the rough road to Kabekona Bay. The fish were biting. They had a wonderful string of beautiful pike. They were having such a good time and Fred was realizing his fondest ambitions.

"Ah! Isn't that a wonderful string," said Fred, as he lifted a portion of his string of pike from the side of his boat and smiled.

"Come on, boys, it's time to go," shouted Doc. It was time to go, and past the time.

"You can go if you want to, but we are going to fish some more," shouted Fred. "This is Remus and Dan's last day. You go on and get supper and we will be there in a little while."

"All right," said Doc. "Don't stay too late, because it looks like we were going to have another storm." 
We had been fishing on the lee side of the lake and did not appreciate the size of the waves and sea.

We tied Doc's boat on behind the launch and the canoe on behind Doc's boat. Ira rode in the canoe. It was splash, splash, splash for the next four hours. We were standing on first one end and then the other. I ran the engine and Charley pumped the water out of the launch. He was busy doing that all the time. It took us a half hour to round Stony Point. When we got on the outside of Stony Point the full sea struck us. I had to cut down the power to almost nothing in order to live in the high waters. We hearled for the Onigum cutoff.

Now this cutoff or channel lays at the extreme end of a very large bay, which is made by the promontories of Pine Point and Stony Point, and down this bay the wind was coming at a terrific pace. The channel leading to Onigum Bay is to some extent hidden by a marshy growth. It is hard to find in the daytime, and when the sun is shining. Charley steered the boat and between us we located the chanmel safely, just as the sun sank behind the major portion of the ground that forms itself into Pine Point. Upon reaching the channel I had to get out and push the boat orer the sandbar. My, but the water was cold and the back lash of the big waves ran over the top of my rubber boots. I then had to hang over the end of the motor and take the weeds off of the propeller. In order to do this I had to remove my oil coat, my hunting coat and my woolen shirt, as I had to get quite a distance under the water. Every now and then a swell would come into the channel from the lake and strike us. We then wormed our way through the inlet and headed for the canal at the extreme end of Onigum Bay. 
On our way we passed an Indian village and the Indian burial ground.

We then headed our boats for Walker. We reached Walker safely, got the mail and started for camp. We reached camp at 10 o'clock. Yes, tired-dog tired; frozen to the bone. We all pitched in, made a fire and started dinner. Everything was in a whizz, and at eleven-thirty in plunged Remus, Dan and Fred, hungry, tired, cold and wet.

"Oh, my goodness, I believe I am going to have a chill," shouted Fred.

"Throw a little more wood into the fire," shouted Remus. "I believe that stove is packed with ice," spoke Remus as he warmed his numb hands.

"Supper is ready, everybody," said Percy. "Come on, Fred can wash the dishes, it will warm his hands a bit."

We sat down to a supper of fresh pike steak, eggs, two and three apiece, as well as a big bowl of oatmeal, potatoes, rutabagas, cucumbers, and for dessert we had pears which Doc had purchased while in Waiker.

"Did you see the northern lights," asked Doc, as we all pulled a chair back from the table. "They were the most beautiful I have ever seen in my life. I never saw Aurora Bolealis as wonderful even in Alaska. Let's go out and see them, boys."

And there, upon stepping outside of our grub house, we saw the most wonderful phenomena I have ever witnessed in my life. There were huge search lights shooting fiom the horizon to the top of the heavens. The sky seerned to be filled with shafts of light which were constantly playing upon the heavens, and then there were curtains of light which shot from the horizon to a point above us. It made a huge chandelier 
in the shape of a drinking glass, which hung over the entire country.

As these lights fell upon the various clouds in the sky the clouds were colored, some dark blue, indigo, purple. There were some silver lined clouds and gold as well.

"Isn't this wonderful!" proclaimed all who were present.

"The people used to think a long time ago that these lightsi were caused by a reflection of light from the icebergs of the north, but now feel positively that it is an electrical display," explained Doc.

"Yes," said Percy, "there are a lot of other things we are going to find out about this old world as time goes on."

"And this Northern light made it so light on the lake that we could see our way home," said Ira. "The power of this light is indeed very wonderful."

"By dig," said Mr. Segur, "I am going to have to go in and sit by the fire, or I'll have a chill sure."

Dan's teeth were chattering and the whole crowd were nearly frozen. We went into the grub house and gathered about the fire. Fred again fell asleep with the Ladies Home Journal before him. Remus and Dan were busy preparing a number of fish to take home with them, so Fred slept on. As we went over to the sleeping cottage we took a farewell look at the Northern lights and went to bed and to sleep. 


\section{CHAPTER XXIII}

The morning of August twenty-seventh, nineteen sixteen, came as usual, but it didn't find anybody astir about the camp at an early hour. Thank goodness? Getting up was postponed until eight thirty. Remus, however, got up at six o'clock and started breakfast. $\mathrm{He}$ did the dishes; the New England conscience of my friend Fred was indeed faint last night in its chiding. This service was indeed thankiolly received.

Here I want to extend to Remus my heartfelt thanks, and the thanks of the Syndicate. God bless him for his kindness.

I busied myself with the cooking and serving. In a little while a large breakfast was consumed-yet, with it, a little philosophy. Fred sat himself comfortably at the table. He was reading the paper. I took a handkerchief, put it on my head, found a piece of an old sheet and made an apron and skirt.

"Fred! You brute! Here you are reading the paper at the breakfast table," I cried, in the shrill feminine voice.

"That's all you think of me," again I shouted, as I threw the dishpan to the floor and started a torrent of tears.

"Gee, Percy!" said Remus, with a smile. "You certainly played that part well. Ha, ha!"

"And how did you know I played it so well, Remus?" "Well," said Fred, with a smile, "this is the first time in thirty-six years, this New Year's; the Missus never would stand for it."

Charley suggested it was not like that at his house. He further suggested that there was a general rush for the paper in the morning. Ira, being a bachelor, 
raised under such pleasant environment, I fear the philosophy of my play will go with him a secret to the grave.

"That was a dandy story of Mr. Stephenson's," said I. "Oh, yes, said Remus. "It started out all right, but, pray forgive me, I fell asleep before he got to the point. Tell it to me again, Percy-"

"Oh, yes, it was about a couple sixty-nine or seventy; oh, yes, getting married."

"Sixty-nine or seventy, getting married," put in Fred, looking very serious.

"A couple sixty-nine or seventy," shouted Remus.

“Oh, my goodness!" cried Fred.

"Doc, what under the sun do folks that age get married for, anyhow?"

Doc cleared his throat, looked very dignified and smiled, and, fearing that Doc might make the matter too plain for explanation later, as doctors generally do, I added the complexity of the legal profession by saying: "Companionship."

"That's it! Companionship! What a wonderful state; what a wonderful word-companionship."

Doc then read us a thorough lecture on the state and the word.

"Yet, with all of that, I have my doubts," suggested Charley.

"Well, why do folks get married, anyway?" asked Fred.

"Well," says Doc, "let us put it this way: Why shouldn't we marry? Some folk get married for one purpose and some another, but, be whatever their purpose may, it should be their ultimate aim to come into a closer relation with the soul of the feminine companion which is in perfect harmony with theirs. Marriage, then, is the highest degree of companionship. 
It must be the highest degree, or marriage will be the rankest of all failures."

So, the matter being thoroughly settled, I lit my corncob pipe and seated myself comfortably at the table.

"This house is in an outrageous condition-it hasn't been swent since we were here last year," said Mr. Pettibone, as he looked about.

"You might try sweeping it; see if anybody cares," shouted Remus.

Fred and Ira waded into the dishes. Percy Field and Clint made themselves scarce. Charley proceeded to sweep out and Remus and Dan packed up.

“Oh, my goorness!" said Mr. Segur. "Things will be like a funeral around here when Remus and Dan are gone."

Charley, Doc, Ira and I went into the interior and bought some vegetables from a farmer's wife and there we got acquainted with two Minnesota "jack-farmers."

In the northern part of Minnesota, a few miles off Leech Lake, on the Northern Pacific Railway, there lives a happy man. He has cleared a farm of twenty acres. $\mathrm{He}$ is the proud father of thirteen or fourteen or fifteen children, ranging from the cradle up. $\mathrm{He}$ works on the section part of the time. He has plenty to eat, fresh air, and everything a man would want but society; yet, a wonderful society-my, my-a whole party for each meal, and three times a day-merry laughter, the play of children-yet he lives in the wilderness, away from the bright lights. What cares he? Judging from their behavior, when they called upon our camp one day with some vegetables, I am inclined to think that there is no room in his life for the bright lights-society, with its frills and pomp. A smiling faced girl or boy, be the face clean or dirty, is far, far 
better to him-and the life he lives is far better than any life he could plan where he could support all of his children so comfortably.

These dear little flowers of the wilderness called on me while I was peeling potatoes.

"Are you the cook?" ventured a little girl, named Hulda.

"Sure, I'm the cook," said I. "How would you like to cook for such a pack?"

"It would be a big job," she ventured again.

And then, having become so very well acquainted, I gathered the little folk about me and told them a fairy story. Oh, how happy I was to watch their eyes glow, and see them feel sad for the little hero-and then Hulda told me a story. It was just a simple story of a little child. "And they lived happily ever afterwards," said she. So I hoped she would, and she hoped I would-and I have been happy ever since. I hope she has.

"Percy," said Doc, as we walked along, "how would you like to live in this state as this farmer does?"

"Not at all," said I.

"Do you suppose a city girl would come to this sort of a life?"

"Don't know," said I. "But it would be a sacrifice on her part."

"Yes," says he. "We wouldn't be mean enough to demand it-yet these people have reached a goalpossibly it is as high as ours in a way."

"Yes," said I. "They are happy, and that is the ultimate goal-and the only difference between them and the others is that of a different mode of being happy; we call one notion progress-the other may be called contentment-yet they are neither contented nor progressive-just happy." 
We purchased a number of things and then walked through the woods to the camp.

There we found Remus and Dan all packed and ready for dinner.

We all busied ourselves with dinner and in time a very heavy dinner was served. It consisted of chicken soup, steak of pike fi:h, rutabagas, potatoes, boiled onions, cabbage, and corn on the cob. We also had some pickled and cooked beets; also a lettuce and tomato salad and hot biscuits. The biscuits and salad Fred prepared, and I cooked the rest of the dinner.

Of course everybody enjoyed this meal.

After the usual pipe of tobacco, we discovered that our beards had long been in need of attention, so we sharpened up our razor's and proceeded to shave. We found that Doc's mustache had given him considerable trouble, when he was attempting to enjoy the soup, and it was getting in his ears, and suggested that he trim it according to the custom of the city.

He took the razor and proceeded with his undertaking, but did not secm to do the job up to the taste of the Syndicate, so Percy was elected to trim Doc up so the people in Walker wouldn't know him. After cutting off about four feet of his mustache, it left him with something which resembled the wings of a butterfly. The Syndicate every one excepting Doc expressed their entire satisfaction with the effort.

Remus also removed the mask of a German general from the lower part of his face and also imitated cut of Doc's mustache, while Charley got to trimming on his to such an extent that he took it all off.

We took a last farewell dip into the lake. The water was so cold, however, that we couldn't enjoy swimming very much. 
After the swim we carried all of the baggage of Remus to the dock and then loaded the big launch with the Syndicate and headed for the place directly across the channel of the inlet to Kabekona Bay. There a large white steamboat stood.

We found this boat occupied by a rich logging contractor who lived at Bemidji, a Mr. Welch, who evidently had gathered quite a fortune logging. He had started a large farm in this country. He had seven hundred acres. A large amount of this was under cultivation. He was making a modern dairy farm out of it. He was an agriculturist.

There we met the foreman, a Mr. Prall, who was very courteous indeed upon meeting us. Of course he recognized our capitalistic bearing and dignity. He took great pains to show us everything about the farm. I was very much surprised to find as much growing as we did. Everything was in the pink of condition. $\mathrm{He}$ told us that it cost about forty dollars per acre to clear the land of the stumps and the underbrush and that the land originally could have been bought for about ten dollars an acre. He told us that any person with enough capital to properly farm could make a return upon his money and labor.

We spent a considerable length of time walking over the farm. Mr. Prall took such an interest in us that we did not get back to camp until six-thirty. There a light supper was served.

After supper we began the undertaking of loading: the baggage of our friends into the boats.

Of course we all had to help load the heavier pieces, and the heavier the load the greater number it took. There was the engine of Dan. It was all boxed ready to be expressed to Kansas City. There were any number of other things crammed into the box. It weighed 
several hundred pounds. And then there was the dock, built by Doc under the direct superintendence of Fred. The launch had to be drawn up to the extreme end of the dock in order to load the engine.

Everybody was on the dock and so was the big engine. Fred was standing at the extreme end, just ready to put the engine into the launch. Doc, Remus and Dan were standing on the dock on each side of the engine, while Charley and Ira were behind the engine near the shore. Percy was just walking onto the dock. "Now, boys, everybody lift," shouted Fred. As everybody started to lift, down went the dock built by Doc, engine, Fred and all. Everybody excepting Fred made a leap for shore, but Fred-he stayed with the engine and gradually sank until he was standing in the cold water up to his waist.

"Oh, my goodness!" shouted Fred, as I rushed to his rescue. He and the engine were safely landed on shore. At that time I remembered the manner in which he had carried on when I had fallen in the lake and all my clothing was soaked-when I had to stop and go for a swim in order that my clothes would dry.

"By dig!" cried he. "Plague take it. Drat it all. Why do I always have to get into it?" And then Fred jumped into another boat, cold, wet, and shivering. Doc went over toward him.

"Now, Fred, go into camp. Change your clothes," shouted Doc.

Fred remained seated in the boat and endeavored to wring the water out of his trousers.

"No, siree. I'll not be stopping the party and be always in the way. Drat it; I'll not go."

The suggestions of Doc ripened into what appeared to be hostile commands and Fred was led away by Doc. 
"You should have seen the expression on Fred's face when the dock gave way and Fred sank," thought Percy to himself. Percy wasn't cruel enough to laugh outright, or especially to stand first on one foot and then the other and laugh until his sides pained him.

When Fred returned, in a little while, in dry clothes, he didn't have much to say.

We finally got our boats loaded and started for Walker. On our way to Walker I was seated at my usual place at the wheel and as the engine pounded on with its monotonous turn this little story flashed through my mind:

A long time ago, when the Mississippi river was the chief mode of transportation from the Gulf to St. Louis, a certain merchant in St. Louis had consigned to him a large number of anvils. He was standing upon the river bank hiring negroes to load the anvils into the steamboat.

"Do you want a hand to load dem dare anvilles into dat dare boat?" inquired a large negro man.

He was informed by the merchant that he did need just such a hand.

"Lawd, man, how much you going to pay for carrying dem dare anvilles across dat dare gang plank into dat dare boat?"

The merchant replied that he would pay fifteen cents an anvil.

"Lawd, suh, dat sure is a little mite of money for such big anvilles. Do it make any difference if I carry two of dem dare anvilles at a time?" drawled the colored man.

The merchant told him that it would make no difference whether he carried two or three; that he would receive fifteen cents for every one he carried across the gang plank. 
The big colored man then put an anvil under each arm and started across the gang plank. Upon reaching the end of the plank, the gang plank broke and the colored man and the anvils fell into the water.

"Look here, man!" shouted the colored man, as he arose to the surface of the water for the third time. "If you don't throw me a rope I suah am going to drop one of these here anvilles."

There was Fred in a similar position with the engine and he true to his cause.

Upon our arrival at Walker we loaded everything on the dock, and here again Fred most fell into the lake. Then we all fell to and pushed the trunks and the luggage up the hill to the station.

We gave our departing friends, Dan and Remus, a list of innumerable messages to deliver upon their reaching Kansas City. This they said they would do.

Just before we were ready to go, I gave Fred a lamp to hold, while I cranked the engine, with special instructions not to lay it down or tinker with it, as it seemed to be in a very delicate state and would fall to pieces at the slightest opportunity. I felt that it was a serious undertaking to put it together on the rolling sea. He took it and immediately put it down with such force that it fell to pieces. He and Doc proceeded to solve the problem of putting it together in the dark. The result of their labor was to put it together backwards. In this way it would not work.

In the course of a half hour and a number of "By digs" and "Plague take its," Mr. Kulander, the gentleman from whom we had rented our camp, came along, and after much pleading for the opportuity to help Fred was permitted to put the lamp together so that it would work. 
After the lamp was put together so it would work, we started for camp.

"Good-bye and God be with you until we meet again," floated over the waves to our friends on shore, as we pushed our boats out into the lake.

I was at the wheel. Everybody signaled for me to drive the boat in a different direction. The steersman paid no attention to the signals of the various captains and soon the launch was passing under the railroad bridge and up to our dock. It was very late when we got to camp. The air was cold and crisp. We built a fire in the stove and after toasting our feet and smoking a few pipes of tobacco went to bed.

\section{CHAPTER XXIV.}

The morning of the twenty-eighth day of August, nineteen hundred and sixteen, found the old sawmill working late. There must have been an exceptionally large number of heavy logs on hand, for the buzz, buzz, buzz was unusually loud. Of course one of the big saws was missing, yet the rest of the crowd seemed to buzz the more.

Awaking at the customary hour, six o'clock a. m. -not by my own motion, but by force of habit-I again felt myself being lulled to sleep by the persistent buzz; and, think of it, this buzz came from one of those fellows who could not lie a-bed in the morning, especially after four-thirty a. m. My early morning companion had gone. I aroused myself from the state into which I had been lulled by the sleepers and dressed. There before me they lay. They looked so very peaceful there. I really thought they needed the 
sleep, so I left them in the mystic realm of dreams while I went about my work.

I called at the cottage at eight o'clock. I found Fred and Doc had just raised in their beds.

"By dig!" shouted Fred, "I just can't get anybody to go swimming with me."

"Well," cried Doc, "I'll go with you, Come on."

And so it was that the two boys bantered each other into going swimming. I say bantered, because the water was too cold for anyone to think of swimming without something of that kind to encourage them.

Breakfast over, dishes washed and placed in their regular order on the table, in readiness for the evening; the lunch box packed, and Percy, having filled the tanks with gasoline, we were ready to embark on the "big drink," as Fred was always bound to call the big lake, where we enjoyed the glorious sunshine and outof-doors of the Northland.

"What's the matter with that do-dad? Plague take it, something always has to go wrong," worried Fred, as he directed Percy in his efforts to fix the engine in the launch. Percy soon had the motor in working orcer and away we motored for Shingobee.

Now Shingobee Bay is located about eight miles south and east of Walker, so we headed our boats first for Walker, and then for that portion of the lake upon which stands the sawmill of Walker, about a half a mile down the lake from Walker.

We soon found there was a lively breeze from the scuth, blowing straight up Walker Bay and kicking up some sea, rough enough so that we kept close in to Morris Point, then cutting across to shelter behind the point, near Walker.

At Walker Remus and Charley stopped for a supply of the weed which has made the red man famous, but 
the other two boats kept right on their course to Shingobee.

Below the sawmill and approaching Shouse's Hole (another famous fishing water for Fred), the fisherman's instinct, which makes a man fish at every opportunity, overcame Fred. He was steering the big boat, but that did not prevent him running out a long line, attached to which was a number eight Skinner spoon, decorated with red flannel and baited with a frog.

"Now," said Fred, "I'm going to get a 'he one." "

We, who watched Fred steer and fish at the same time, were convinced that it was a man's job, but Fred's bump of perseverance is well developed, and steer and fish he must, and did. Had the boat left a visible track, others following might have wondered why the course, as it was so like a corkscrew. Twice he almost landed on the shore where a landing was not intended, but he didn't land the "he one."

The entrance to Shingobee Bay is spanned by a long railroad bridge of the Northern Pacific Railway. Under this bridge we passed and upon motoring three or four miles came to a place where a beautiful, murmuring brook emptied itself into the bay. On our way there was much discussion as to the best place to camp. We decided, however, to tie our boats at this inlet and camp here.

This is indeed a delightful camping ground. The shore has been improved with a rickety old dock. Not far from the shore is a wonderful spring of cold, pure water, over which has been built a rickety old summer house. Some distance back from this inlet, upon the top of a high hill, stands a summer cottage of, as we were told by a native of this vicinity, two old maids. 
The country in and about Shingobee is very wild. It is surrounded by high hills, which are covered with second growth pines and shrubs, the virgin forest having been cut down. The air about the place is filled with the rich perfume of the pine trees. I was tired and sleepy, so I stretched myself on the rickety old dock and fell asleep, while the rest of the boys went for a fish.

When they had tired of fishing-for the first timepossibly as they were down on their luck, they returned to the old dock. I was informed that it was the notion of Charley that I had had a better sleep than they had fish.

Upon arrival of the Syndicate they made a careful examination of our surroundings. We found that a motor boat had been hurriedly pulled upon shore and there deserted. This was apparent, as the motor was exposed to the wind and rain and the boat was half full of water. Its owner had doubtless left in great haste.

Doc went un to the cottage on the hill, but found no trace of the living, although, through the windows, evidence of late occupancy could be seen, as the bedding and clothing were scattered about. This, according to Charley, intensified the mystery of the deserted boat.

"A mystery," said Charley, "is always interesting."

There was a delightfully uncanny feeling about these premises, and it gave us a topic for much speculation; still we were unable to solve the problem.

In the meantime, and during our discussion, Dan and Ira had climbed the hill immediately behind our camp, and through which ran a beautiful bubbling brook. On the return of the wanderers, we concluded once again to give Fred another chance to fish. Thus it 
was necessary for us to hurry through with our dinner of fish, cheese, milk, bread and coffee.

Ira and I went canoeing. We paddled our canoe into the extreme southern portion of Shingobee Bay in search of Shingobee River, which flows from Shingobee Lake. We found the river so filled with bog that it was impossible for us to paddle to Shingobee Lake. We returned to the place where we had camped about four o'clock and sighted the other boat trolling.

They had fished all day long, with little success, so Fred, Charley and Ira decided they would go to Onigum for a visit with friends there, with whom they had spent some previously happy vacations. They took the large boat, with Ira as skipper, and after passing under the bridge laid their course for Onigum.

After going some distance, Ira discovered the keys to the grub house in his pocket. Consternation! Here was a serious offense indeed. It was one which had stirred up a great deal of trouble on previous occasions, when some forgetful one would carry off the keys, and others, upon arriving home first, would have to boost the lightest one of the crowd, usually Doc or Dan, through a window, and when the luckless one returned he got the full benefit of the indignation of the whole crowd. Memories of these occurrences brought terror to the soul of Ira, so by dint of loud shouts and waving of hats the attention of the other boat was attracted and the keys delivered-much to the relief of Ira.

Did you ever approach Onigum via Agency Bay on a bright summer afternoon? It is a sight one cannot forget. The high point near the canal is carelessly wooded, with here and there a stately pine which towers majestically. Upon passing through the canal, a small inlet to Onigum Bay, which has been made for 
the Indians, we come into view of the Indian school buildings, and in the foreground the Mercer Memorial. Further to the right, the row of houses occupied by the government agency employes. This point, upon which stand these improvements, juts out into the lake like a battleship. Upon looking farther on down the shore line of the bay we see the Indian village, and beyond, in the distance, the Indian burying ground.

There is no very great difference between the burying ground of the Indians and that of other people, yet their graves mark not only their difference of opinion of hereafter but their appreciation for their loved ones. They build rude little houses over the graves, and in the front of these houses they cut a hole, large enough for a bumble bee to pass, for the spirits to use.

Doc, Charley and Ira landed at the dock at Onigum, just below the Mercer Memorial Episcopal church. This church is a quaint sort of a building. Its appearance recalled to the minds of Fred and Charley the Sunday they attended services at the church at the instance and insistence of Miss Colby, the missionary. No doubt for penance. For a time I can imagine it was possibly a novel thing, but as the lessons, songs, and sermon, which was by no means a short one, were in the Ojibway tongue, I have no doubt but that it developed into deep penance. Of course I can readily appreciate how Fred escaped the strain and the greater part of it by sleeping soundly, and I hope quietly, while sitting straight up in a most dignified manner.

There was also another custom about this church, I have been informed by Charley, which they contend they will never forget. That is that the contribution plate is placed at the altar, and the contributors came forward-and why? 


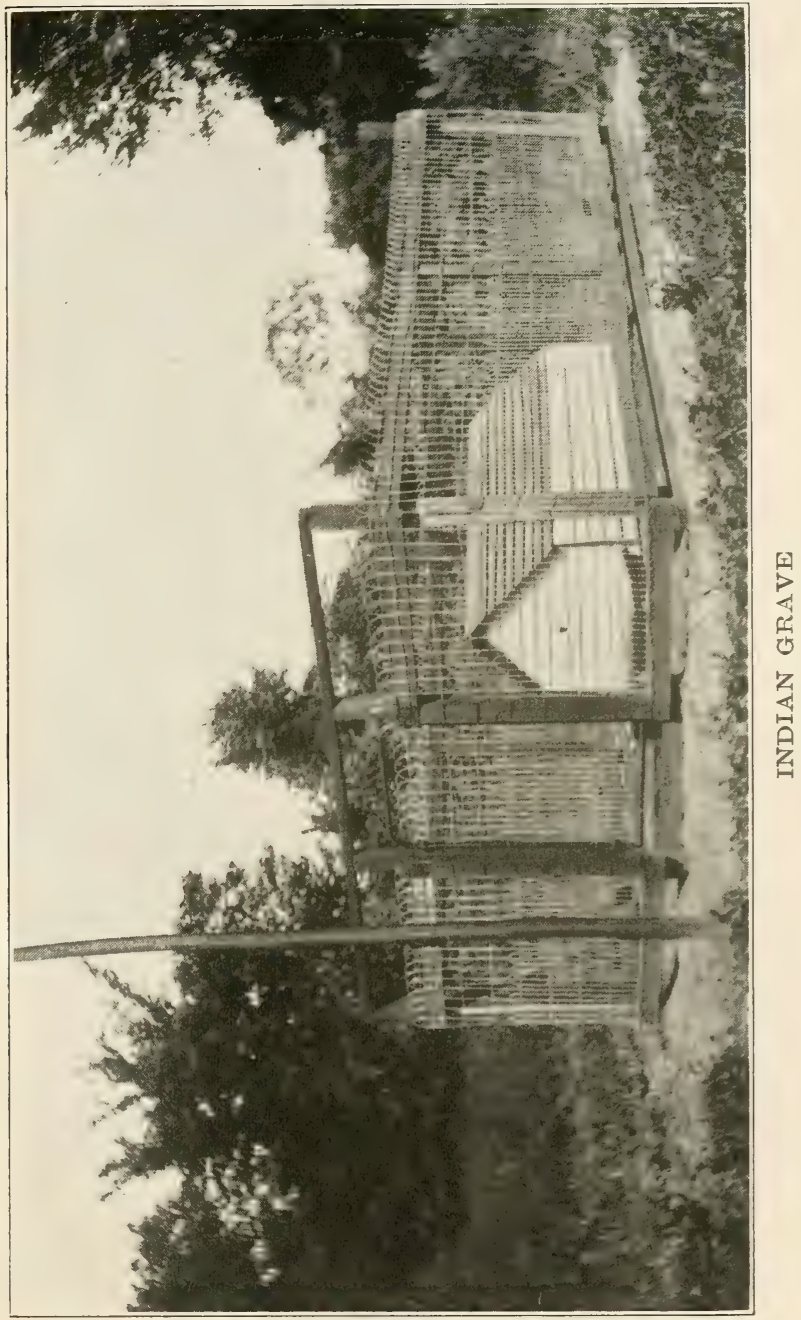



As Charley, Fred and Ira walked on up to the top of the hill, they came to the cottage of Miss Colby. It is a white, one-story sort of a house, nestling close to the church, vine-covered. By the house were rose bushes. In the yard were flowers of golden glow, sweetpeas, mignonette, rose geraniums-some cheerful bloom for all summer, typical of the cheery and happy person who lives there.

Ah, Miss Colby! Have you ever met this good woman? It is a pleasure for anyone to know her. She is reasonably plump, not very tall, wears a pleasant face at all times; and, while her face isn't the kind which some folk rave about on the stage, yet it is one of those good, wholesome faces which we soon -yes, very soon, indeed, enjoy seeing. She has kind blue eyes. To look into her eyes is to view the inner chambers of goodness. She has given more than twenty years of her life to the work of bringing comfort and hope for better things, both for here and hereafter, to her dusky wards, in a missionary capacity.

Fred, Ira and Charley always feel sure of a warm welcome at the home of Miss Colby; and so do everybody else. They and we feel much at home there. And why not? Isn't there a step at the gate which was built by Fred and Charley? And do not Fred and Charley know exactly where the ax should be put. Can't either of them go into the kitchen in the dark and find the water pail?

It is a rare treat to visit Miss Colby. Our eyes grow large and frequently dim when she tells of the many thing's her life with the Indians necessitated; her going out and coming in, day after day, year after year, summer and winter. And, mind you, they have 
winter at Leech Lake. They also have days of wind, when it is not possible to cross the big water, yet, if anyone must go, Miss Colby is always the one to go. She came to the Ojibway Indians when the railroad was no nearer than Brainard and when all travel was by canoe, sled or wagon.

My! what experiences she has had. One night, when she was busy with her household cares, alone, no one near on whom she could call, the door opened and in walked six big buck Indians in full war paint, with tomahawks, knives and the symbols of war. They filed into the room, walked over to the fire and sat down without speaking a word. They watched her in this way for more than an hour, and, notwithstanding this fact, Miss Colby went about her work undisturbed. A curious member of our party upon asking if she was afraid, was informed that she didn't dare permit the Indians to think she was.

Then, again, on a very dark and cold winter night, word came to her that an Indian was dying, so through the forest alone Miss Colby went; out into the storm of winter, across the water, to bring help and good cheer to those who suffered; and those who suffered were only dirty Indians-a copper-colored Indian was dying in the Northern wild. Many had died before without the assistance and kind words of a good woman, yet, on this cold winter night, Miss Colby must go. She must go because his own people cared little for his comfort. She found the Indian sick with tuberculosis. He died. The next day it was very coldthirty below zero. There had to be a funeral, and this service Miss Colby had to preach. To do this she had to stand out in the ice and snow and await the digging of the grave, which had to be dug through the frozen ground. She did this with the only reward that the 
Indians would learn to know and to respect our God, to be civilized.

When you think of these things, and know that they are possibly only two of the many, many cruel hardships which this good woman had undergone for the glory of God, we cannot help but admire her goodness; and when we ask ourselves this question, What have we done, what shall our answer be?

After visiting Miss Colby, Fred, Ira and Charley went over to call on Mr. and Mrs. Silas Walter. They are two good folk of the Indian reservation. Mr. Walter is the general carpenter, millwright, cabinetmaker and casketmaker for the Indians, and a general utility man about the reservation. They are two mighty good people. Mrs. Walter is a proud mother of a number of good boys. She knows that boys, even rather old ones, are always ready to eat.

Does the great bigness of things have its effect on character? It would certainly seem so. When it is given one to know, as we know, our friends at Onigum, we feel that they have absorbed and made a part of themselves something of the wholesomeness of God's great out-of-doors.

Doc and Percy, upon receiving the keys to the grub house, headed for Kabekona Bay. We prepared a splendid supper, and as we were about to sit down to the table we heard the hearty voices of our companions.

"And how did you find the darling Miss Colby?" shouted Percy.

"And Dad Walter and Mrs. Walter?" added Doc.

"Oh, very well, indeed," put in Charley.

"Come, pull up your chair; here's a fine supper awaiting you," cried Percy. 
"Supper! What do we want with supper? Why, we have dined with the Walters. Yum-yum, ice cream! Great saucers full; rich, made from the cream of Dad's famous 'Can't Hook Cow.' Ah, my dear boys, the cake! Huge pieces, four-layer chocolate cake! Ah, frosted cake! Pike fish might be good, but nobody's boys or girls ever had a better home, or food either, than that of Dad Walter," said Charley.

Notwithstanding the ice cream and cake, the boys paid their respects to the supper we had prepared.

By the time dishes were put in shape everyone had quietly crept away to bed, leaving the camp to the buzz of the mosquitoes and the sleepers.

\section{CHAPTER XXV.}

It was decided last night that we should get up at five-forty-five and take another trip to Durant Bay. At five-forty-five this morning, Tuesday, August 29th, 1916, everybody in and about the camp was very busy, and at seven o'clock we headed our boats for Durant Bay. This morning the air was exceedingly fine and we arrived there at a seasonable hour prepared for fishing. I had again prepared a cold lunch so that Fred would not have to take the time out from his hard and consistent fish. He expected to make a big catch today. Upon arriving at the place we had camped before at Durant Bay, Fred, Doc and Charley took the row boat and Ira and I the canoe. We all went for a fish. The waves were very high; in fact, the lake was so rough that we only caught enough fish to eat, notwithstanding the fact that we fished all day long. We started home at six o'clock and then followed another battle with the waves. 
We reached camp at nine-thirty p. m. and started supper. We were all hungry, tired, cold, wet and worn out. I prepared a reasonably good supper. Mr. Segur again said his New England conscience would keep him awake if the dishes were not washed, so we all went to work on the dishes and in the course of half an hour were ready for bed.

\section{CHAPTER XXVI}

Wednesday, August 30, 1916, was a very important day in and about our camp. Our vacation time had been fast slipping away. We had been so very, very busy that we hardly appreciated the fact that this was the morning for our packing up and making ready our debut into civilization. We were to leave the simple life; to leave the beautiful lake with its cold springs and its fish; the covering of the blue sky; the fresh air; the Indians; to take off our rough clothing, our winter wear; to put on a high collar; to dress as custom and civilization demanded.

The sun rose this morning at its usual time, but not the Syndicate. Percy Field woke from force of habit at 6 o'clock. He could hear the lazy chiming of the cowbells and the buzz of the sleepers. He knew they were all tired, so he, like the rest of the crowd, slept late this morning. Around the hour of eight-thirty the Syndicate one by one dressed and went about their duties.

Breakfast was served; it was a very good one. Doc made a reputation for himself on cakes this morning. Fresh fish was cooked by Percy, as well as oatmeal to the taste of all concerned. There was no place suggest- 
ed to go; everything seemed to suddenly become melancholy and glum; there was the packing to be done. What can be more irksome from a vacation; to break camp, and to take such steps as tended to end a happy camping party?

This was indeed a tiresome undertaking. I didn't like it and I don't think anybody else did.

Everybody hustled about, however, and in a little while had things ready for traveling. I took a swim in the cold waters of the lake and so did the rest of the party. My, but it was cold today, and I didn't enjoy the swim at all.

Charley and Ira went for a fish in Kabekona Bay. They caught a few pike, which we cooked for dinner, and after dinner came the job of assorting our fishing paraphernalia and the packing.

"By dig," shouted a certain member of the Syndicate, apparently much peeved about something, "I made one suggestion the first day I was here and nobody paid any attention to it. By dig, I'll not make another."

Somebody had asked the member his views about having a large boat sent from Walker for our baggage.

Upon this utterance of Fred another member of the Syndicate, now the proud possessor of a sporty mustache, sprang to his feet and told Fred a thing or two.

"Now, Doctor, dear, pardon me, please. I didn't understand the situation," said Fred amicably, as he embraced Doc.

"Very well," said Doc, "but don't you fly off half cocked, or something will happen to you, my dear boy."

"Yes, doctor dear. Now don't blame me for making you hear my side of the question," said Fred, as he started another loud discussion, which in time came to a happy ending. 
"Fred and Doc are certainly two peaceful childrenthey never have any differences at all," suggested Percy with a smile.

"Indeed they are," put in Charley.

"Yes," said Percy, "they remind me of a little incident which took place in my home a good many years ago. I was sitting in my reading room, which at that time was just across from the kitchen.

" "Go on with you, you little old burr-headed black man. You jes boss aroun', boss aroun' and boss aroun'! Now hush you' big mouth, little old bow-legged man, or I'll take this hare butcher knife and cut off your little old bullet head," was the conversation of our old colored woman and her husband. Realizing the probability of her husband opening his mouth again, I dropped the paper and rushed out into the kitchen.

" 'Charity! What does this mean. Put down that butcher knife,' I shouted, as I beheld Charity standing over her husband, most in the act of decapitating him.

“'Fo' da Lawd's sake, Mistah Field,' said Charity, greatly astonished at my interpretation of their conversation. 'Oh, Lawdy, we's jest visitun.'"

"Yes," added Charley, "that is evidently the case with some folk," as he winked at Fred and Doc, "you have to know them to understand them."

We then loaded all of the heavy luggage into the boats, shaved and dressed ourselves in our city clothes.

"Mr. Charles I. Pettibone, I believe?" spoke Percy, with a bow, as he walked over to where Charley was standing.

"Yes," said Charley, "and this is Mr. Field. I am glad to meet you in this far away place, but there are two other distinguished gentlemen."

"Yes, Mr. Frederick W. Segur and Doctor H. O. Leonard. They are from Kansas City. I know them 
very well there. They must be strangers in these parts. And there is Mr. Ira Pettibone."

"Mr. Ira Pettibone, I am delighted, indeed, to see you," announced Mr. Field, as he shook hands with Ira.

We then loaded our light baggage into the boats very carefully and then with a great deal of pains everybody else got in the boats.

"Careful there, Fred," shouted Doc, "you'll give my city friends a wetting. Now, Percy, start the engine and keep close to the shore, our city friends don't want to get wet."

Thus Messrs. Frederick W. Segur, Charles I. Pettibone, Doctor Homer O. Leonard, Ira Pettibone and Percy C. Field rode to Walker.

After starting the engine I stood up in the boat and upon turning my face toward camp beheld the sun, a magnificent sunset. It appeared to be sinking into Lake Benedict; and, as it was gradually swallowed up by the lake, it lighted the bay with a rich reddish, fiery stream, leaving everything peaceful and quiet, excepting for the monotonous pound of our engine and the gentle swish of the water as it passed our boat and rolled into huge waves behind. There in the distance was the inlet to Lake Benedict, and far away to the right the inlet to Kabekona River, the various other wild shore lines as well.

The old grub house and the tent houses were rapidly being left behind. They looked cold and desolate. A loon cried and its weird call proclaimed that the creatures of the forest and lake reigned supreme.

As we approached the railroad bridge, I turned my face to the bow, to avoid striking the bog or the piers. "Good-bye, Kabekona! Good-bye, Lake Benedict!" shouted Mr. Frederick W. Segur, as he waved his hand 


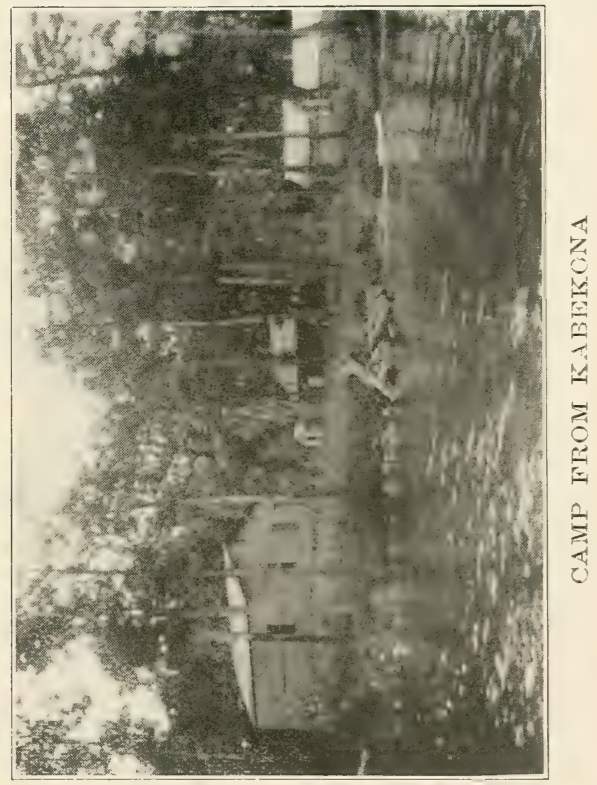



and threw a kiss to the respective haunts of our pleasure.

"Good-bye, Steamboat Bay, and good-bye, Squaw Point, the Narrows, and your watery growth," said Doc, as he gave them a farewell salute.

"Now, don't let us forget Durant Bay," shouted Ira.

"Or Shingobee, or Ottertail-yes, good-bye to you all, our happy hunting ground; farewell, until we meet again," proclaimed Doc with a voice of sadness.

And everybody murmured a fond Amen.

\section{CHAPTER XXVII.}

We reached Walker in due time; unloaded our boats, put our trunks upon a push cart, and pushed the cart and baggage up the hill to the station platform. Ah, never before was a hill so steep or a load so heavy.

We then went over to the restaurant, across the railroad tracks, and had a very poor supper.

After supper Percy registered at the Chase Hotel and wheeled his trunk and grips to The Annex, or Lake View Hotel, while Mr. Segur went to the railroad station.

"I want to do some figuring, may I use your high desk?" inquired Mr. Segur of the station agent, a very fat and jovial fellow.

"Help yourself, my dear sir, help yourself," the fat man added, as Mr. Segur took charge and spread a bundle of papers upon the desk. He figured on first one side of a very large sheet (big enough to wrap a turkey in with ease) and then the other side. Never before did Mr. Frederick W. Segur appear to be so popular with the boys and the station agent, and never 
before did the station agent and the rest of the Syndicate desire so to talk with Fred. We talked at him, to him, and possibly through him, but he just kept on a-figuring and adding and talking to himself.

As the train which was to take the Syndicate back to their loved ones and civilization pulled into Walker, Mr. Frederick W. Segur gathered up his papers and presented each member with an itemized statement of his proportionate expense. These bills were immediately paid, and the party boarded the train.

I told everybody good-bye as they stepped on the train. When I did, the words seemed to choke in my throat. It was my fate to remain, to stay in the fresh air, to keep away from home and my loved ones; to keep away from the pollen of the ragweed and golden rod and the earthy smell of Missouri.

The train pulled out and with it the sunlight of my life in and about Walker.

"They have gone," said I to myself as I walked to my lonely room in The Annex, "but not forever, for I shall meet them again in Kansas City."

I did, and to my great pleasure.

\section{THE END.}









\section{4}

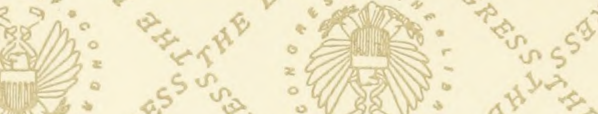

2

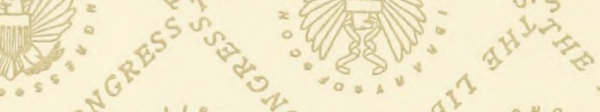

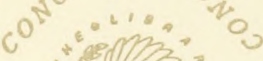

$0_{0}^{2}$

,

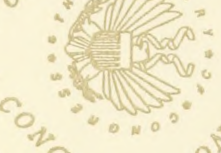

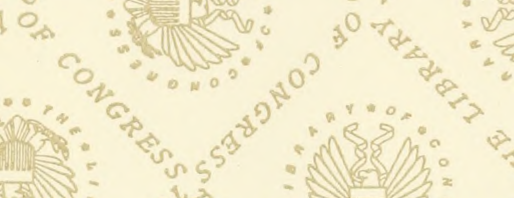

(3)

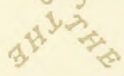

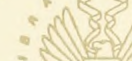

030 से से

से

-

gen

-Ollas"

$\hat{\gamma}^{5}$

$=$ 난

- n

का सेत्रे

8

s. 


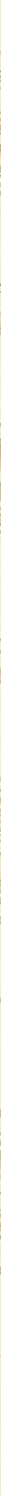




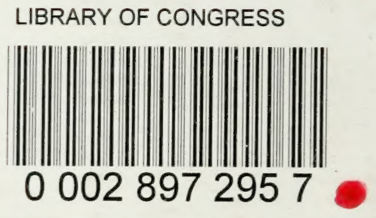

